\title{
General question of world science
}

Collection of scientific papers

on materials

XIV International Scientific Conference

15.10.2021

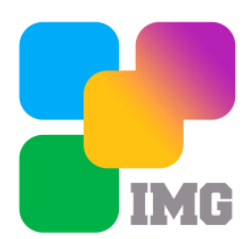

Luxembourg 2021 
General question of world science. Collection of scientific papers, on materials of the international scientific-practical conference 15.10.2021, Ed. SIC "Science Russia", 2021. - 104 p.

Общие вопросы мировой науки. Сборник научных трудов, по материалам международной научно-практической конференции. 15.10.2021. Изд. "Наука России", 2021. - 104 с.

DOI 10.18411/gq-15-10-2021

The collection of scientific papers of the materials collected from different areas of scientific knowledge. This publication contains all the materials that were sent to the XIV international scientific conference "General question of world science"

The collection is intended for researchers, teachers and students

All materials contained in the book, published in the author's version. The editors do not make adjustments in scientific articles. Responsibility for the information published in the materials on display, are the authors.

The electronic version of the collection is available online scientific publishing center «Science Russia" Site center: science-conf.com

UDC 001.1

LBC 60

(c) LJournal, 2021 


\section{Contents}

SECTION I. MEDICINE

Крукович Е.В., Бондарь Г.Н., Туманова Н.С., Осипенко Е.А. Метод

биоимпедансметрии в оценке эффективности профилактики и реабилитации у детей школьного возраста на амбулаторно-поликлиническом этапе

Кязимова В.А., Гахраманова С.М., Бахшалиев А.Б. Показатели липидного профиля крови у больных с артериальной гипертензией в зависимости от уровня витамина D .. 12

SECTION II. PEDAGOGY.

Белисова А.А. Коррекционно-педагогические приемы и средства по формированию познавательной активности у детей младшего школьного возраста с ЗПР

Дудар Т.Е., Уляшева Л.Г. Личность как результат образовательного процесса: действующие парадигмы и вектор их развития ..

Егошина Н.Г. Роль этнокультурных ценностей в жизни современных студентов.

Захарова Т.В., Шабунова А.А. Особенности исследования социального здоровья у детей младшего школьного возраста с ограниченными возможностями здоровья .........26

Нестеренко В.Г., Матвиенко Л.М. Секрет успеха подготовки учителя в Финляндии 32

Шаповалов М.В. Информационно-коммуникационные технологии в системе воспитательной работы учреждений общего образования

SECTION III. MATHEMATICS 40

Kandalova M.A. Mathematical methods and their application in the sectors of the national economy (case study of agribusiness)

SECTION IV. BIOLOGY

Шмакова О.В., Концевая С.Ю. Сравнительные аспекты информативности ультразвуковой и рентген диагностики при уролитиазе у мелких домашних животных

SECTION V. CONSTRUCTION 60

Панченко Н.М. О необходимости учёта влияния параметров надёжности строительной системы на её производительность (на примере процесса производства земляных работ экскаваторным комплектом)

SECTION VI. ASTRONOMY .66

Плеханов П.Г. Третий пояс в солнечной системе и его первые открытые объекты...... 66

SECTION VII. EARTH SCIENCES.

Kharchenko I.Ya., Kharchenko A.I. Technologies for the formation of soil-cement massifs when developing underground space in reclaimed lands and artificial islands 
SECTION VIII. RESOURCE SAVING

Москаленко В.М. Влияние скорости перехода на энергоэффективность морского судна 80

SECTION IX. AGRICULTURAL SCIENCES. .85

Куржиев Х.Г., Апажев А.К., Шекихачев Ю.А., Хажметов Л.М. Исследование влияния гумата +7 «Здоровый урожай» на урожайность сельскохозяйственных культур в условиях Кабардино-Балкарской Республики. 85

SECTION X. ECONOMY .91

Мамадаезова А.А. Рынок труда и конкурентоспособность молодых женщин ГБАО... 91

SECTION XI. CULTUROLOGY 95

Бочков П.В. История возникновения и деятельности общины священника Александра Кожевникова в Республике Коми. 95

SECTION XII. JURISPRUDENCE .98

Медведев В.Г. Деятельность белых правительств в налоговой сфере на севере и северозападе России в годы Гражданской войны 


\title{
SECTION I. MEDICINE
}

\author{
Крукович Е.В. ${ }^{1}$, Бондарь Г.Н. ${ }^{2}$, Туманова Н.С. ${ }^{2}$, Осипенко Е.А. ${ }^{1}$ \\ Метод биоимпедансметрии в оценке эффективности профилактики и \\ реабилитации у детей школьного возраста на амбулаторно-поликлиническом \\ этапе \\ ${ }^{1}$ ФГБОУ ВО «Тихоокеанский государственный медицинский университет» \\ Минздрава России \\ ${ }^{2}$ ФГБОУ ВО «Дальневосточный федеральный университет»
} (Россия, Владивосток)

doi 10.18411/gq-15-10-2021-01

\section{Аннотация}

Физическое развитие является одним из критериев эффективности профилактики и реабилитации, дополнительным методом может быть метод биоимпедансметрии. Проведена комплексная оценка состояния здоровья 1024 детей и подростков (девочки 521, мальчики 503) I и II групп здоровья. Изучены показатели физического развития (масса тела, длина, окружность груди, ИМТ), структурные компоненты тела: жировая масса тела, безжировая масса тела, внутриклеточная жидкость, внеклеточная жидкость, активная клеточная масса, общая вода, общая жидкость в организме и др., определен липидный профиль. Выявленные типы (особенности) распределения ФР, структурно-телесных компонентов организма и липидного спектра у детей и подростков у здоровых детей I и II группы здоровья.

\section{Abstract}

Physical development is one of the criteria for the effectiveness of prevention and rehabilitation; an additional method can be the method of bioimpedance measurement. A comprehensive assessment of the health status of 1024 children and adolescents (521 girls, 503 boys) of I and II health groups was carried out. The indicators of physical development (body weight, length, chest circumference, BMI), structural components of the body were studied: body fat mass, lean body mass, intracellular fluid, extracellular fluid, active cell mass, total water, total body fluid, etc., determined lipid profile. Identified types (features) of RF distribution, structural-bodily components of the body and lipid spectrum in children and adolescents in healthy children of I and II health groups.

Неблагоприятная динамика показателей здоровья детей и подростков требует изменения мер профилактики и реабилитации для его сохранения [1-6]. Целью профилактики и реабилитации в педиатрии на амбулаторно - поликлиническом этапе является не только вернуть больному ребенку здоровье, но и развить его физические и психические функции до оптимального уровня $[7,8,9]$. В статье 40 Федерального закона «Об основах охраны здоровья граждан в Российской Федерации» от 21.11.2011 № 323Ф3 указано, что медицинская реабилитация направлена на полное или частичное восстановление, или компенсацию нарушенных или утраченных функций.

Первым и основным звеном профилактики и реабилитации детей является детская поликлиника [10]. Задачи амбулаторно - поликлинического этапа реабилитации это - диспансерное динамическое наблюдение, проведение вторичной профилактики и динамическая оценка эффективности реабилитации.

Несмотря на большое количество научных материалов критериев оценки эффективности профилактики и реабилитации недостаточно. Важным, достаточно лабильным и чувствительным к внешним и внутренним факторам показателем в оценке здоровья детей, в том числе и при проведении профилактики и реабилитации, является 
показатель физического развития (ФР) [1-6]. Современные методы оценки предполагают не только оценку ФР по индексу массы тела (ИМТ), по центильным или сигмальным таблицам, но и изучение составляющих массы тела (МТ), наиболее точно отражающих особенности ФР, баланса энергии и степень удовлетворенности организма в необходимых веществах $[4,5,11,12]$. Одним из методов оценки составляющих МТ является метод биоимпедансметрии (БИМ), доступный и простой в использовании метод, позволяющий диагностировать как исходный статус организма, так и оценить динамику состояния, что очень важно в контроле реабилитации детей, имеющих индивидуальные темпы ФР. Наиболее часто метод БИМ используют в реабилитации детей с ожирением, метаболическим синдромом, сахарным диабетом и другими заболеваниями являющимися проблемой современности $[4,5,11,12]$.

Изменение компонентов структуры тела: жировой массы тела (ЖМТ), безжировой массы тела (БЖМТ), внутриклеточной жидкости (ВНКЖ), внеклеточной жидкости (ВКЖ), активной клеточной массы (АКМ), общей воды (OB), общей жидкости в организме (ОЖ), активной клеточной массы (АКМ), доли активной клеточной массы (ДАКМ) и др. могут существенно меняться в зависимости от характера питания, физической активности, индивидуальных особенностей обмена веществ и энергетического метаболизма и является весьма важным прогностическим критерием при реабилитации на амбулаторном этапе наблюдения детей и подростков. Лабораторным подтверждением и диагностическим критерием этих изменений является липидограмма крови.

Цель исследования: на основе изучения показателей физического развития, компонентного состава тела, липидограммы оценить риск нарушения здоровья детей школьного возраста и обосновать комплекс профилактических и реабилитационных мероприятий.

Материалы и методы. Работа представляет комплексное исследование, проведенное в ФГБОУ ВО ТГМУ Минздрава России, в КГБУЗ «Владивостокский клинико - диагностический центр», ГБУЗ «Краевая детская клиническая больница № 2» г. Владивостока, учреждениях общего среднего образования г. Владивостока. На основе добровольного согласия обследованы дети с I и II группами здоровья. В зависимости от возраста исследуемая группа была распределена на подгруппы: I - (7- 9 лет) составила 202 человека, II - (10-14 лет) - 221 человек, III - (15-17 лет) - 601 человек. Оценка и распределение по группам здоровья проведены в соответствии с общепринятыми рекомендациями Института гигиены детей и подростков по показателям здоровья (приказ МЗ РФ от 30.12 .2003 г. № 621) и согласно приложению № 2 к приказу №1346 н от 21.12.2012 г., дополнительно проведено анкетирование детей и их родителей по собственно разработанной анкете, включающей вопросы о режиме и характер питания, двигательной активности, употреблении алкоголя, наличии фактора курения, вредных привычек, об информированности о состоянии своего здоровья. Количественная оценка компонентов тела проведена методом БИМ, на аппарате «Диамант - Аист» (г. Санкт-Петербург). Фрагмент научной работы проведен в диагностической лаборатории «Авиценна+». Определены биохимические показатели: глюкоза, общий холестерин, триглицериды, липопротеиды высокой и низкой плотности и др. методом фотометрического измерения коэффициента отражения с тест-полосками с помощью экспресс-анализатора CardioChek PA. Оценку полученных результатов и комплексный системный анализ данных проводили методом вариационной статистики с вычислением средней арифметической $(\mathrm{M})$, ошибки средней арифметической $(\mathrm{m})$, доверительного коэффициента Стьюдента (t) при заданном уровне значимости (р). Были рассчитаны величины доверительного интервала, проведен корреляционный анализ данных (определяли связи между варьирующими признаками и формы, их тесноту и проверяли достоверности выборочных показателей корреляции) и кластерный анализ (группировка данных с 
помощью метода полной связи, в котором сходство между кандидатами на включение в существующий кластер и любым элементом этого кластера не было меньше некоторого порогового уровня). Статистическую обработку материала выполняли с помощью специализированных пакетов прикладных программ для исследований («Excel 2010 и «Statistica 6.0, 8.0»).

Результаты и обсуждение. Проведена комплексная оценка состояния здоровья детей и подростков в следующих возрастно - половых группах: I группа, возраст 7 - 9 лет, 202 чел. (100 девочек и 102 мальчика соответственно), II группа 10 - 14 лет, 221 чел. (120 девочек и 101 мальчик), III группа, 15 - 17 лет, 601 чел. (301 девочка и 300 мальчиков). В исследуемой группе, у 354 детей (1/3), определена I группа здоровья, а у $670(65,4 \%)$ - вторая, с более чем одним отклонением и/или заболеванием в состоянии здоровья. Вторую группу здоровья определили такие состояния и/или заболевания как: отягощенный аллергический анамнез, диагностирован у $1 / 4$ детей $(30,1 \%$ девочек и $20,5 \%$ мальчиков), патология ЛОР-органов - у 20,9\% девочек и 20,2\% мальчиков, более $1 / 3$ детей исследуемой группы относились к группе часто болеющих детей (ЧБД). Средние значения и доверительные интервалы показателей ФР представлены в таблице 1, отражая возрастную динамику нарастания МТ и возрастно - половые различия.

Таблиия 1

Средние значения и доверительные интерваль показателей физического развития (М $\pm m$ [доверительный интервал])

\begin{tabular}{|c|c|c|c|}
\hline Показатели & $M \pm m$ [ДИ] & $M \pm m$ [ДИ] & $M \pm m$ [ДИ] \\
\hline девочки & I группа $(n=100)$ & II группа $(n=120)$ & III группа $(n=301)$ \\
\hline масса тела, кг & $\begin{array}{c}29,69 \pm 0,73 \\
{[20,00-50,00]}\end{array}$ & $\begin{array}{l}46,18 \pm 0,89 \mathbf{\Delta} \\
{[24,00-75,00]}\end{array}$ & $\begin{array}{c}54,75 \pm 1,16 \mathbf{m} \\
{[39,00-94,00]} \\
\end{array}$ \\
\hline длина тела, см & $\begin{array}{c}131,22 \pm 0,79 \\
{[117,00-155,00]}\end{array}$ & $\begin{array}{c}155,81 \pm 0,81 \mathbf{\Delta} \\
{[125,00-176,00]}\end{array}$ & $\begin{array}{c}164,58 \pm 0,69 \square \\
{[155,00-177,00]}\end{array}$ \\
\hline окружнность груди, см & $\begin{array}{c}63,92 \pm 0,59 \\
{[54,00-79,00]}\end{array}$ & $\begin{array}{l}73,76 \pm 0,61 \mathbf{\Lambda} \\
{[60,00-93,00]} \\
\end{array}$ & $\begin{array}{l}76,58 \pm 0,76 \bullet \\
{[64,00-99,00]}\end{array}$ \\
\hline ИМТ & $\begin{array}{c}17,06 \pm 0,29 \\
{[11,24-25,51]}\end{array}$ & $\begin{array}{l}18,93 \pm 0,28 \mathbf{\Lambda} \\
{[13,60-26,26]}\end{array}$ & $\begin{array}{c}20,21 \pm 0,42^{*} \\
{[15,76-36,72]}\end{array}$ \\
\hline мальчики & I групnа $(n=102)$ & II группа $(n=101)$ & III группа $(n=300)$ \\
\hline масса тела, кг & $\begin{array}{c}29,76 \pm 0,64 \\
{[19,00-49,00]}\end{array}$ & $\begin{array}{l}48,93 \pm 1,31 \mathbf{\Lambda} \\
{[24,00-98,00]}\end{array}$ & $\begin{array}{c}66,64 \pm 1,55 \mathbf{\square} \\
{[52,00-99,00]}\end{array}$ \\
\hline длина тела, см & $\begin{array}{c}132,86 \pm 0,89 \\
{[113,00-154,00]}\end{array}$ & $\begin{array}{c}157,63 \pm 1,22 \mathbf{\Delta} \\
{[130,00-184,00]}\end{array}$ & $\begin{array}{c}176,52 \pm 0,78 \square \\
{[163,00-194,00]}\end{array}$ \\
\hline окружность груди, см & $\begin{array}{c}64,22 \pm 0,60 \\
{[53,00-80,00]}\end{array}$ & $\begin{array}{c}76,74 \pm 0,80 \mathbf{\Delta} \\
{[60,00-105,00]}\end{array}$ & $\begin{array}{c}83,94 \pm 1,00 \square \\
{[70,2-107,00]}\end{array}$ \\
\hline ИМТ & $\begin{array}{c}16,61 \pm 0,24 \\
{[9,49-24,68]}\end{array}$ & $\begin{array}{l}19,38 \pm 0,33 \mathbf{\Delta} \\
{[13,79-31,28]}\end{array}$ & $\begin{array}{c}21,48 \pm 0,46 \square \\
{[17,17-32,37]}\end{array}$ \\
\hline
\end{tabular}

Примечание: * $p \leq 0,05$ между II и III группой; $\bullet p \leq 0,01$ между II и III группой; $\mathbf{\Delta} p \leq$ 0,001 между I и II группой; $\mathbf{p} \leq 0,001$ между II и III группой.

Средние значения показателя МТ выявлены более чем у 50\% детей. Выше среднего изменения МТ диагностированы у 1/3 подростков, преимущественно в возрасте 15-17 лет и у девочек, тогда как МТ ниже нормы встречалась в 2 - 13\% случаев в зависимости от возраста (7-9 лет - у 7\% девочек и 7,6\% у мальчиков; $10-14$ лет - 11,7\% и 12,9\% соответственно; $15-17$ лет - 4,6\% и 2\% соответственно). Показатель ДТ в исследуемых возрастных группах имел характерные физиологические закономерности нарастания, выявлены индивидуальные темпы роста у девушек в III группе. Показатель ОГ у $1 / 2$ мальчиков (всех возрастных групп) соответствует возрасту, тогда как у девочек ОГ соответствовала норме только в I и II группах, в других группах имела тенденцию к более низким значениям. Половина $(48,9 \%)$ обследованных детей имели гармоничное развитие. Дисгармония ФР за счет дефицита МТ у мальчиков в среднем составила 
$6,9 \%$, у девочек $-7,8$ \% (в зависимости от возраста отмечены достоверные различия $(\mathrm{p} \leq 0,01))$. Определение соматотипа показало, что в I группе у девочек в 45,5\% встречался мезосоматотип, в 41,8\% - макросоматотип, в $12,7 \%$ микросоматотип. У мальчиков, больше чем у половины, выявлен макросоматотип $(64,5 \%)$, мезосоматотип у $29,2 \%$, микросоматотип - у 6,3\%. Во II группе, не зависимо от пола, у более половины детей определен макросоматический тип развития (50,9\% у девочек и 60,9\% у мальчиков), в III группе около 50\% детей имели мезосоматический тип конституции.

В соответствии с целями и задачами нашего исследования определены средние значения и доверительные интервалы показателей составляющих МТ (таблица 2).

Таблица 2

Средние значения и доверительные интерваль показателей составляющих массы тела ( $M \pm m$ [доверительный интервал])

\begin{tabular}{|c|c|c|c|}
\hline Показатели & $M \pm m$ [ДИ] & $M \pm m$ [ДИ] & $M \pm m$ [ДИ] \\
\hline девочки & I групnа $(n=100)$ & II групnа $(n=118)$ & III групnа $(n=65)$ \\
\hline жсировая масса, кг & $\begin{array}{c}5,39 \pm 0,34 \\
{[0,21-14,9]}\end{array}$ & $\begin{array}{r}10,03 \pm 0,44 \mathbf{\Delta} \\
{[0,39-22,39]}\end{array}$ & $\begin{array}{l}14,03 \pm 0,78 \square \\
{[4,74-44,92]}\end{array}$ \\
\hline внеклеточная жидкость, л & $\begin{array}{c}5,72 \pm 0,11 \\
{[3,32-8,25]}\end{array}$ & $\begin{array}{l}9,23 \pm 0,17 \mathbf{\Delta} \\
{[4,85-22,89]}\end{array}$ & $\begin{array}{l}10,12 \pm 0,14 \mathbf{\square} \\
{[7,04-12,71]}\end{array}$ \\
\hline внутриклеточная жидкость, л & $\begin{array}{c}9,05 \pm 0,20 \\
{[5,04-14,53]}\end{array}$ & $\begin{array}{r}15,16 \pm 0,28 \boldsymbol{\Lambda} \\
{[6,29-25,64]}\end{array}$ & $\begin{array}{c}17,94 \pm 0,32 \mathbf{\square} \\
{[10,06-22,95]}\end{array}$ \\
\hline общая жидкость, л & $\begin{array}{c}14,78 \pm 0,29 \\
{[9,23-22,23]}\end{array}$ & $\begin{array}{l}24,43 \pm 0,43 \mathbf{\Delta} \\
{[11,15-48,53]}\end{array}$ & $\begin{array}{c}28,36 \pm 0,40 \text { ] } \\
{[20,26-34,85]}\end{array}$ \\
\hline безжировая масса тела, кг & $\begin{array}{c}24,37 \pm 0,46 \\
{[16,36-35,20]}\end{array}$ & $\begin{array}{l}36,09 \pm 0,56 \mathbf{\Delta} \\
{[21,46-69,51]}\end{array}$ & $\begin{array}{c}40,73 \pm 0,54 \square \\
{[29,67-49,25]}\end{array}$ \\
\hline$A K M, \kappa 2$ & $\begin{array}{c}14,69 \pm 0,28 \\
{[10,41-22,64]}\end{array}$ & $\begin{array}{l}22,13 \pm 0,36 \mathbf{\Delta} \\
{[11,93-36,15]}\end{array}$ & $\begin{array}{c}25,78 \pm 0,36 \mathbf{\square} \\
{[19,06-32,55]}\end{array}$ \\
\hline общая вода, л & $\begin{array}{c}17,9 \pm 0,34 \\
{[11,97-25,77]}\end{array}$ & $\begin{array}{l}26,52 \pm 0,41 \mathbf{\Delta} \\
{[15,71-50,88]}\end{array}$ & $\begin{array}{c}29,80 \pm 0,39 \square \\
{[21,72-36,05]}\end{array}$ \\
\hline мальчики & I груnпа $(n=100)$ & II группа $(n=101)$ & III групnа $(n=56)$ \\
\hline жсировая масса, кг & $\begin{array}{c}4,82 \pm 0,34 \\
{[0,78-18,60]}\end{array}$ & $\begin{array}{l}8,27 \pm 0,61 \mathbf{\Delta} \\
{[0,48-38,54]}\end{array}$ & $\begin{array}{l}10,71 \pm 1,03 \bullet \\
{[1,71-31,24]}\end{array}$ \\
\hline внеклеточная жидкость, л & $\begin{array}{c}5,82 \pm 0,10 \\
{[3,63-8,37]}\end{array}$ & $\begin{array}{l}9,83 \pm 0,25 \mathbf{\Delta} \\
{[5,00-17,40]}\end{array}$ & $\begin{array}{l}12,82 \pm 0,19 \square \\
{[9,21-15,86]}\end{array}$ \\
\hline внутриклеточная жидкость, л & $\begin{array}{c}10,29 \pm 0,21 \\
{[5,88-14,92]}\end{array}$ & $\begin{array}{r}16,98 \pm 0,37 \boldsymbol{\Lambda} \\
{[8,95-26,56]}\end{array}$ & $\begin{array}{c}22,72 \pm 0,29 \square \\
{[18,70-27,60]}\end{array}$ \\
\hline общая жидкость, л & $\begin{array}{c}16,15 \pm 0,29 \\
{[9,51-22,48]}\end{array}$ & $\begin{array}{l}26,70 \pm 0,60 \mathbf{\Delta} \\
{[14,33-43,96]}\end{array}$ & $\begin{array}{c}35,54 \pm 0,46 \mathbf{\square} \\
{[27,91-43,46]}\end{array}$ \\
\hline безжсировая масса тела, кг & $\begin{array}{c}24,97 \pm 0,37 \\
{[17,17-33,00]}\end{array}$ & $\begin{array}{l}40,67 \pm 0,99 \mathbf{\Delta} \\
{[21,73-68,86]}\end{array}$ & $\begin{array}{c}55,93 \pm 0,74 \square \\
{[44,00-68,79]}\end{array}$ \\
\hline$A K M, \kappa 2$ & $\begin{array}{c}15,65 \pm 0,26 \\
{[10,45-21,51]}\end{array}$ & $\begin{array}{r}25,19 \pm 0,64 \mathbf{\Lambda} \\
{[1,92-40,96]} \\
\end{array}$ & $\begin{array}{c}35,51 \pm 0,46 \mathbf{\square} \\
{[28,91-43,00]}\end{array}$ \\
\hline общая вода, л & $\begin{array}{c}18,28 \pm 0,27 \\
{[12,57-24,40]}\end{array}$ & $\begin{array}{l}29,77 \pm 0,72 \mathbf{\Delta} \\
{[15,91-50,41]}\end{array}$ & $\begin{array}{c}40,94 \pm 0,54 \mathbf{\square} \\
{[32,21-50,35]}\end{array}$ \\
\hline
\end{tabular}

Примечание: $\mathbf{\Delta} p \leq 0,001$ между I и II группой; • $p \leq 0,05$ между II и III группой; $\boldsymbol{\square} \leq$ 0,001 между II и III группой.

При количественной оценке показателя ЖМТ выявлено снижение у 65\% детей (130 чел.) I группы, тогда как нормальное и повышенное количество жировой массы тела было у 16,5\% (33 ребенка) и 18,5\% (37 детей) соответственно. Во II группе снижение ЖМТ отмечалось в 48,9\% случаев (107 детей), диагностировано повышенное содержание ЖМТ у 32,4\% (71 ребенок), что вероятно связано с началом и течением пубертатного периода, лишь 18,7\% детей (41 чел.) этой группы имели нормальную ЖМТ. У 50\% детей (52 чел.) III группы диагностирован недостаток ЖМТ, показатели ЖМТ в пределах «нормальных» значений выявлены в 24,8\% случаев (30 детей), а 
избыток ЖМТ - у 32,2\% (39 детей). Отмечается увеличение количества мальчиков от 57,1 до 67\% с недостаточным количеством ЖМТ во все возрастные периоды, тогда как у девочек недостаток ЖМТ диагностируется преимущественно в I группе (63\%). От $45,8 \%$ до $76 \%$ обследованных имели нормальные показатели БЖМТ не зависимо от пола и возраста, что позволяет считать их общий нутриционный статус соответствующий возрасту.

Внеклеточная и внутриклеточная жидкость, а так же жидкость, находящаяся в организме в связанном состоянии, составили показатель ОВ. Показатели в пределах нормы ОВ диагностированы у 134 ребенка (67\%) I группы, избыток - у 65 детей (32,5\%). Во II группе - нормальные показатели ОВ отмечались более чем у половины детей $(51,9 \%)$, в III группе - у 75 детей $(61,8 \%)$, избыточное содержание ОВ колебалось в обеих группах от 30 до $34 \%$.

В результате проведения БИМ нами определено, что в I группе нормальное значение ОЖ имели 73\% детей (146), у 5,5\% - выявлен недостаток, а у 21,5\% - избыток ОЖ, у детей II группы определена похожая тенденция, однако в III группе процент детей с нормальными значениями ОЖ увеличился до $85,2 \%$, отражая созревания процессов регуляции, а дисбаланс в виде избытка ОЖ и недостатка выявлен у 11,2\% и 3,6\% школьников. Распределение ВКЖ носили следующий характер: в пределах нормальных значений имели более $28 \%$ детей 1 и 2 групп вне зависимости от пола, тогда как у подростков этот показатель увеличивался до 45,4\%. Но в то же время в 63,5\% случаев дети и подростки имели превышение данного показателя, что характеризует недостаточность процессов преобразования, хранения и использования энергии, которое в некоторой степени способствует снижению работоспособности у школьников. Значения показателя ВНКЖ соответствовали пределам нормы и были снижены у незначительного количества детей. Показатели распределения АКМ представлены на рисунке 1 .
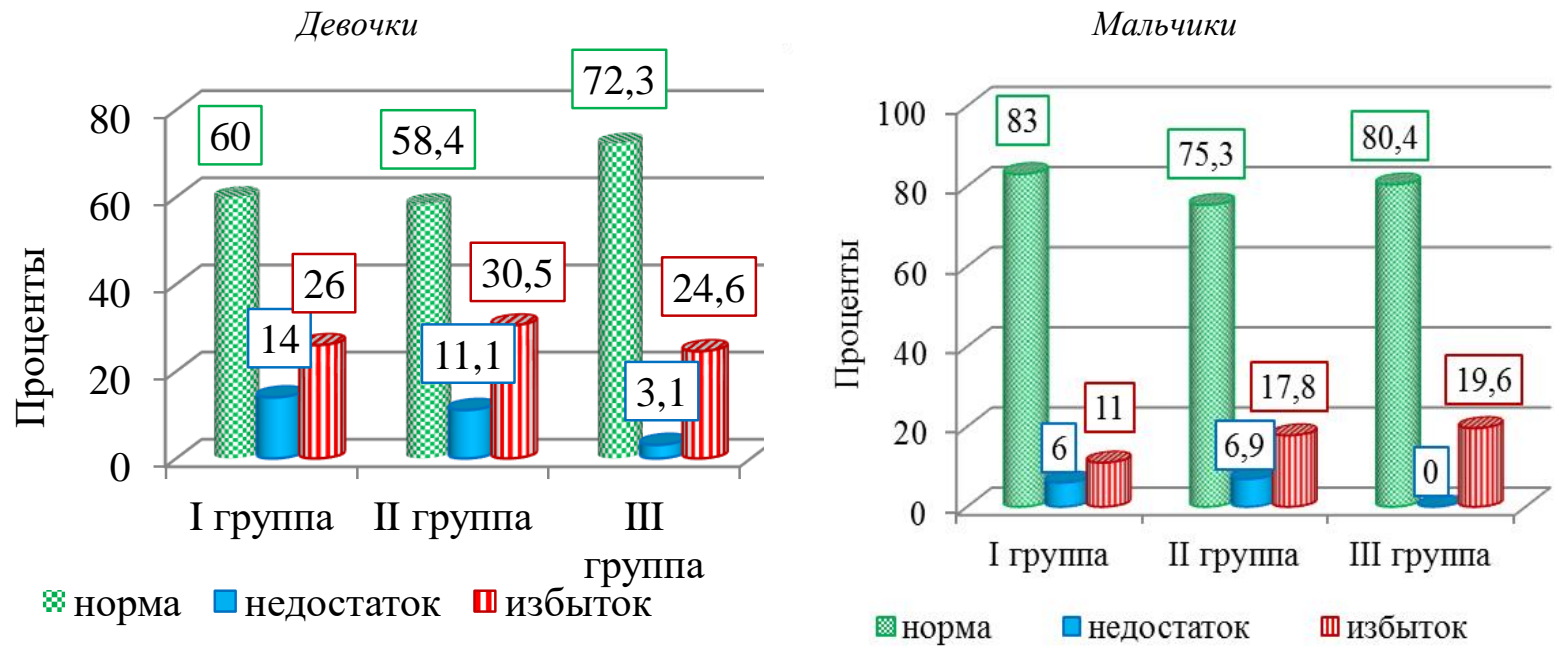

Рисунок 1. Проиентное содержание активной клеточной массы у детей и подростков обоих полов

АКМ включает в себя клетки мозга, нервной системы, мышц и внутренних органов, и именно в ней происходит активное сжигание жира. Процент энергозатрат в организме складывается из следующих факторов: основной обмен, пищевой термогенез и энергозатраты на физическую деятельность, поэтому, чем больше АКМ, тем больше затрачивается энергии. Изменение показателя АКМ связано с нарушением питания и двигательной активности детей в исследуемой группе (подтверждено данными анкетирования). Выявленное у детей исследуемой группы снижение АКМ характеризует недостаточность клеточного питания, нарушение функций внутренних 
органов, прием слишком большого количества «пустых» калорий и недостаток физической активности.

При оценке ДАКМ выявлено, что ее нормальное процентное значение в организме уменьшается с возрастом (от 7 к 17 годам) у детей обоих полов. Снижение ДАКМ указывает на недостаточность клеточного питания, нарушение функций внутренних органов, прием слишком большого количества «пустых» калорий и недостаток физической активности. У $1 / 3$ школьников выявлено снижение ДАКМ, особенно у девочек в возрасте 7-14 лет.

Анализ липидограммы в исследуемой группе выявил, что у мальчиков показатели холестерина были наиболее высокими во II группе $4,07 \pm 0,08$, у девочек в третьей, важно отметить широкий диапазон данного показателя в исследуемой выборке от 2,50 до 6,89 . Показатели холестерина имели достоверные различия $(\mathrm{p} \leq 0,01)$ у детей разного возраста и пола во II и III группах. Важно, что во всех возрастных группах минимальное значение триглицеридов составляло 0,57 ммоль/л, что отражает дефицит некоторых жирных кислот, необходимых для участия в процессах метаболизма, тогда как максимальный интервал достигал до 2,39 ммоль/л у мальчиков III группы, указывая на необходимость персонифицированного подхода к оценке данного показателя с учетом оценки ФР и питания. Средние значения и интервалы показателей липидограммы представлены в таблице 3.

Таблиия 3

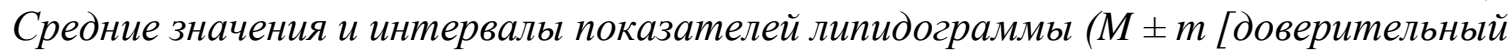

\begin{tabular}{|c|c|c|c|c|}
\hline \multirow{3}{*}{ показатель } & \multirow{3}{*}{ пол } & $(M+m$ ГДИл & $(M+m[\Pi И])$ & $((M+m[\pi U])$ \\
\hline & & $(M \pm m[2 и])$ & $(M \pm m[2 n])$ & $((M \pm m[\alpha И]))$ \\
\hline & & $I(n=100)$ & $\Pi(n=118)$ & III $(n=65)$ \\
\hline \multirow{2}{*}{ Холестерин, ммоль/л } & девочки & $\begin{array}{c}4,23 \pm 0,09 \\
{[2,57-7,80]} \\
\end{array}$ & $\begin{array}{c}4,36 \pm 0,07 \\
{[2,78-7,51]}\end{array}$ & $\begin{array}{c}4,37 \pm 0,12 * * \\
{[2,59-6,89]}\end{array}$ \\
\hline & мальчики & $\begin{array}{c}3,99 \pm 0,08 \\
{[2,50-6,12]}\end{array}$ & $\begin{array}{c}4,07 \pm 0,08 \\
{[2,50-6,80]}\end{array}$ & $\begin{array}{l}3,77 \pm 0,08 \bullet \\
{[2,59-5,06]}\end{array}$ \\
\hline \multirow{2}{*}{$\begin{array}{c}\text { Липопротеиды высокой } \\
\text { плотности, ммоль/л }\end{array}$} & девочки & $\begin{array}{c}1,64 \pm 0,07 \\
{[0,66-2,39]}\end{array}$ & $\begin{array}{c}1,54 \pm 0,09 \\
{[0,93-2,25]}\end{array}$ & $\begin{array}{c}1,42 \pm 0,13 \\
{[0,86-2,09]} \\
\end{array}$ \\
\hline & мальчики & $\begin{array}{c}1,79 \pm 0,11 \\
{[0,83-3,70]}\end{array}$ & $\begin{array}{l}1,39 \pm 0,11^{*} \\
{[0,78-2,44]}\end{array}$ & $\begin{array}{c}1,51 \pm 0,21 \\
{[0,63-3,84]}\end{array}$ \\
\hline \multirow{2}{*}{$\begin{array}{c}\text { Липопротеиды низкой } \\
\text { плотности, ммоль/л }\end{array}$} & девочки & $\begin{array}{c}2,22 \pm 0,18 \\
{[0,36-5,16]}\end{array}$ & $\begin{array}{c}2,57 \pm 0,31 \\
{[1,05-4,32]}\end{array}$ & $\begin{array}{c}2,43 \pm 0,21 * * \\
{[1,82-3,60]}\end{array}$ \\
\hline & мальчики & $\begin{array}{c}2,23 \pm 0,23 \\
{[1,11-4,16]}\end{array}$ & $\begin{array}{c}2,62 \pm 0,32 \\
{[1,04-4,02]}\end{array}$ & $\begin{array}{l}1,65 \pm 0,28 \mathbf{\square} \\
{[0,60-2,85]}\end{array}$ \\
\hline \multirow{2}{*}{ Триглищериды, ммоль/л } & девочки & $\begin{array}{l}1,12 \pm 0,09 * * \\
{[0,57-2,70]}\end{array}$ & $\begin{array}{l}0,83 \pm 0,10 * \\
{[0,57-2,29]}\end{array}$ & $\begin{array}{c}0,95 \pm 0,06 \\
{[0,67-1,28]}\end{array}$ \\
\hline & мальчики & $\begin{array}{c}0,75 \pm 0,05 \\
{[0,57-1,82]}\end{array}$ & $\begin{array}{c}0,89 \pm 0,10 \\
{[0,57-1,75]}\end{array}$ & $\begin{array}{c}1,05 \pm 0,18 \\
{[0,57-2,39]}\end{array}$ \\
\hline
\end{tabular}

Примечание: * $p \leq 0,05$ между I и II группой; $\mathbf{p} \leq 0$,05между II и III группой; $\bullet p \leq 0,01$ междуII и III группой, ** $p \leq 0,05$ между девочками и мальчиками.

При изучении размаха показателей ЛПВП отмечена тенденция к более высоким числовым выражениям. С возрастом у девочек ЛПВП снижались (в I группе - 1,71 ммоль/л, во II и III группах - 1,46 ммоль/л), что вероятно связано с более высоким уровнем эстрогенов к началу пубертатного периода. Значения ЛПНП у мальчиков имели достоверные $(\mathrm{p} \leq 0,05)$ различия только во II и III группах, причем в последней

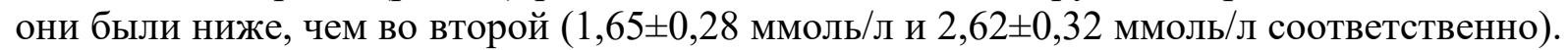
У девочек во II и III группах средние значения ЛПНП имели тенденцию к росту в

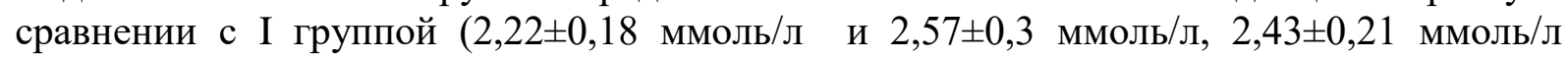
соответственно). Таким образом, при анализе липидограммы детей 7-17 лет выявлены достоверные $(\mathrm{p} \leq 0,05)$ возрастно - половые различия между девочками и мальчиками во II и III группе по показателям ЛПНП и холестерином и у детей I группы по 
показателю - триглицериды. Выявлен широкий диапазон размаха показателей в различные возрастные периоды с тенденцией к повышению холестерина, триглицеридов (в группе мальчиков) и ЛПНП (преимущественно во второй возрастной группе).

С учетом полученных данных проведен анализ взаимосвязей показателей (корреляционный анализ) ФР, структурных компонентов тела и липидограммы. По каждому ребенку было выделено и просчитано 34 признака, из которых 13 показателей ФР, 15 показателей структурных компонентов тела и 6 биохимических показателей крови, затем был проведен кластерный анализ целью которого было выявление природы взаимодействий и взаимосвязей исследуемых показателей (с учетом уже полученных до этого данных проведенного корреляционного анализа). Отбор признаков производился в соответствии с требованиями к данным для проведения процедуры кластерного анализа (на основании рассчитанных значений корреляции Пирсона (матриц парных корреляций)). В качестве метода проведения кластерного анализа был выбран метод общей полной связи признаков, используемых для проведения кластеризации. В качестве метрики был выбран коэффициент корреляции Пирсона. Кластерный анализ был проведен для 6 групп (выборок) данных: девочки/мальчики - I группа дети от 7 до 9 лет, девочки/мальчики - II группа - от 10 до 14 лет, девочки/мальчики - II группа - от 15 до 17 лет, построены дендрограммы распределения признаков.

На основании кластерного распределения нами выделены типы распределения показателей: 1 тип с недостатком составляющих ЖМТ, БЖМТ, ОВ; 2 тип с дисбалансом показателей липидограммы ОХ, ЛПНП, ТГ у девочек во II и III группах, у мальчиков в возрасте 7- 9 лет (I группы); 3 тип детей с нормальным физическим развитием и дисбалансом ДАКМ. Способы оценки результатов исследования ФР, структурно-телесных компонентов организма и липидного спектра у детей и подростков представлены рационализаторскими предложениями [13-15] и позволит при профилактике и реабилитации детей в амбулаторно - поликлинических условиях оценить дисбаланс исходного статуса и динамику состояния здоровья ребенка.

Выводы. Физическое развитие является одним из критериев эффективности профилактики и реабилитации, так как между периодами лечения, медицинской реабилитации (восстановительного лечения) и профилактикой нет четкой границы. Восстановительное лечение продолжается до тех пор, пока здоровье ребенка не достигнет соответствующему возрасту уровню и одним из мало затратных методов контроля эффективности проводимых мероприятий является метод БИМ. Выявленные типы (особенности) распределения ФР, структурно-телесных компонентов организма и липидного спектра у детей и подростков у здоровых детей I и II группы здоровья расценены нами как группа детей с повышенным риском нарушения здоровья, нуждающиеся в проведении реабилитационных мероприятий на амбулаторном участке и персонифицированным подходом к коррекции дисбаланса ФР на основе изменений структурных компонентов тела и липидограммы. Кроме того, нами выявлено, что из всех показателей наименьшее влияние на распределение показателей ФР, структурных компонентов тела и показателей липидограммы оказывают признаки САД, ДАД, ОГ, ОЗ, ИМТ, ВКЖ, ВНКЖ, АКМ, ЛПВП, а наиболее сильно подвержены изменениям факторы: возраст, пол, МТ, ДТ, ОТ, ЖМТ, БЖМТ, ДАКМ, ОВ, ХС, ЛПНП, ТГ, последние так же нуждаются в контроле при реабилитации.

$$
* * *
$$

1. Баранов А.А., Кучма В.Р., Скоблина Н.А., Сухарева Л.М., Милушкина О.Ю., Бокарева Н.А. Лонгитудинальные исследования физического развития школьников г. Москвы (1960-е, 1980-е, 2000-е гг.) // Физическое развитие детей и подростков. Выпуск VI. под ред. Баранов А.А., Кучма В.Р.- ПедиатрЂ. - 2013 .- С. 33-43. 
2. Бочарова О.В. Особенности состояния здоровья детей в зависимости от физического развития на педиатрическом участке // Вестник современных ис-следований. - 2018. - № 4.2 (19). - С. 37 - 39.

3. Арустамян М.А. Мониторинг физического развития детей до года г. Еревана // Евразийский союз ученых. - 2019. - № 12-2 (69).- С. 44-48.

4. Гаджикеримов Г.Э., Аль - Зрер К.М. Основные тенденции заболеваемо-сти детей от рождения до 14 лет в Российской Федерации // Российский педиат-рический журнал. - 2020, т: 23. - № 6. - С. 396.

5. Давыдова А.В., Логачев М.Ф. Актуальные проблемы развития повы-шенной массы тела и ожирения у детей и подростков // Детская больница. - 2014. - № 1.- С. 31 - 36.

6. Матосян К.А., Оранская А.Н., Пустовалов Д.А., Черепкова Е.В., Скот-никова Ю.В., Бурдюкова Е.В., Анищенко А.П., Гуревич К.Г., Ханферьян Р.А. Особенности качественного состава жировой ткани в организме в пубертатном и постпубертатном возрасте с учетом возраста, пола, уровня физической активно-сти и характера питания // Вопросы питания. - 2015. - № 5.- С. 88 - 94.

7. Романцова Т.И. Молекулярные механизмы регуляции массы тела как мишени патогенетической терапии ожирения // Терапия. - 2015. - № 4 (4). - С. 71-78.

8. Ненашева А.В., Аминов А.С. Физическое развитие и физическая подго-товленность детей 6-14 лет из социально неблагополучных семей, эффектив-ность системы реабилитации // Теория и практика физической культуры. - 2015. - № 4. - С. 59-61.

9. Шевцов А.В. Современные образовательные возможности для развития физической реабилитации в направлении «адаптивная физическая культура» // Адаптивная физическая культура. - 2020. - т. 82. - № 2. - С. 6 - 9 .

10. Пичугина Е.В. Развитие направления физической реабилитации лиц молодого и старшего возраста средствами адаптивной физической культуры в физкультурно - оздоровительном учреждении // MODERN SCIENCE. - 2019. - № 6-1. - C. 49-56.

11. Маскова Г.С. Прогноз эффективности реабилитационного лечения де-тей с ожирением в поликлинике // Практическая медицина. - 2020. - Т.18. - № 6. - С. 170 - 175.

12. Черных С.П., Руднев С.Г., Николаев Д.В., Старунова О.А. Физическое развитие и состав тела российских детей по данным биоимпедансного обследо-вания в центрах здоровья // Вопросы питания. - 2014. - т. 83. - № S3. - C. 46.

13. Paul Simmet, K George Mm Alberti, Francine Kaufman, Naoko Tajima, Martin Silink, Silva Arslanian, Gary Wong, Peter Bennett, Jonathan Shaw, Sonya Caprio. The metabolic syndrome in children and adolescents - an IDF consensus re-port // Pediatr Diabetes. - 2007. - № 8.- P. 299 - 306.

14. Кузнецова Н.С., Бондарь Г.Н., Крукович Е.В. Способ диагностики степеней риска развития метаболических нарушений у детей и подростков на этапах их онтогенеза: рац. предложение; Тихоок. гос. мед. ун-т. - Владивосток, 2013. - 11 с. (заявл. 5.11.2013; выд. удостоверение № 2817 2.12.2013).

15. Кузнецова Н.С., Бондарь Г.Н., Крукович Е.В., Хмельницкая Е.А. Спо-соб дифференцированной физической нагрузки в зависимости от величины ин-декса массы тела (ИМТ) у детей и подростков. рац. предложение; Тихоок. гос. мед. ун-т. - Владивосток, 2013. - 14 с. (заявл. 25.12.2013; выд. удостоверение № 2821 10.01.2014).

16. Кузнецова Н.С., Крукович Е.В., Бондарь Г.Н. Способ оценки результа-тов исследования структурно-телесных компонентов организма и липидного спектра у детей и подростков: рац. предложение; Тихоок. гос. мед. ун-т. - Вла-дивосток, 2013. - 12 с. (Заявл. 14.08.2013; выд. удостоверение № 28162.12 .2013$)$.

\section{Кязимова В.А., Гахраманова С.М., Бахшалиев А.Б. Показатели липидного профиля крови у больных с артериальной гипертензией в зависимости от уровня витамина D}

Азербайджанский Медицинский Университет Министерства Здравоохранения Азербайджанской Республики (Азербайджан, Баку)

doi 10.18411/gq-15-10-2021-02

Как известно, эссенциальная артериальная гипертензия (АГ) является полиморбидным заболеванием, к факторам риска развития которой относятся как наследственная предрасположенность, так и нарушения липидного, минерального обмена, гормонального статуса [1-3]. Исследования последних лет подчеркивают важность увеличения плазменного уровня витамина D для уменьшения риска различных дислипидемий, ассоциированных с такими кардиоваскулярными 
заболеваниями, как АГ, инсульт, инфаркт миокарда [4-8]. Регулярное поддержание нормального уровня витамина $\mathrm{D}$ способствует двукратному уменьшению риска развития атеросклероза, что имеет важное значение в профилактике СС3.

Цель исследования - изучение особенностей изменения параметров липидного спектра крови у больных с артериальной гипертензией в зависимости от концентрации витамина D.

\section{Материал и методы}

Одномоментное клиническое исследование проводилось сотрудниками кафедры Клинической фармакологии на базе Кардиологического Отделения Терапевтической Клиники Азербайджанского Медицинского Университета в период с сентября 2018 по январь 2020 года.

В исследование вошли 34 больных с установленным ранее диагнозом: артериальная гипертония (АГ) 1-2 степени по классификации Европейского Общества Кардиологов и Европейского Общества по Гипертонии 2018 года (2018 ESC/ESH

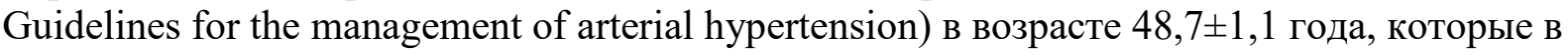
зависимости от уровня витамина D были разделены на 2 группы. В первую группу (группа I) вошли 19 больных (8 мужчин и 11 женщин) с низкими значениями уровня витамина D (0-30 нг/мл), а во вторую (группа II) - 15 пациентов (6 мужчин и 9 женщин) с оптимальными значениями уровня витамина D (30-60 нг/мл) согласно клиническим рекомендациям Российской ассоциации эндокринологов по диагностике, лечению и профилактике дефицита витамина D у взрослых 2016 года. Пациенты не принимали холестерин снижающих препаратов и постоянную гипотензивную терапию. Контрольную группу сравнения составили 17 практически здоровых добровольцев (7 мужчин и 10 женщин) без артериальной гипертензии с оптимальными значениями уровня витамина D (30-60 нг/мл) в среднем возрасте $43,4 \pm 0,9$ года.

Содержание витамина D в организме больных с АГ и здоровых добровольцев определялось путем определения гидроксивитамина D $(25(\mathrm{OH}) \mathrm{D})$ в плазме крови иммуноферментным методом. Показатели липидного спектра крови изучали на основании анализа содержания общего холестерина (OХC), липопротеидов низкой и очень низкой плотности (ЛПНП, ЛПОНП), липопротеидов высокой плотности (ЛПВП), триглицеридов (ТГ) иммуноферментным методом.

В исследование не включались пациенты с АГ 3-степени, симптоматическими АГ, гипертоническими кризами, ишемической болезнью сердца (ИБС) III-IV ФК, хронической сердечной недостаточностью (XCH) III-IV ФК, сахарным диабетом (СД) 1 и 2 типа, хронической почечной недостаточностью 3-5 стадии, тяжелой печеночной недостаточностью, заболеваниями щитовидной железы, надпочечников, онкологическими заболеваниями.

При статистической обработке результатов исследования использовался пакет прикладных программ Statistica 10,0 фирмы StatSoft.Inc (США). Данные представлялись в виде числа наблюдений (п), среднего значения признака (M), стандартного отклонения (SD). В виду асимметричности распределения проверка нулевой гипотезы проводилась с использованием непараметрического критерия U (Вилкоксона-Манна-Уитни). В качестве порогового уровня статистической значимости принималось значение $\mathrm{p}<0,05$.

\section{Результаты и обсуждение}

Большинство исследований последних лет доказывают благоприятное влияние оптимального уровня витамина D на поддержание нормального баланса липидного спектра крови [4;5;7]. Анализируя результаты 10 плацебо-контролируемых двойных слепых исследований с витамином D, Jorde R. с соавторами в 2011 году показали положительную связь сывороточного витамина D c антиатерогенными липопротедами высокой плотности и отрицательную с атерогенными липопротеидами низкой плотности [4]. Корейские ученые в 2019 году изучили взаимосвязь между уровнем 
витамина D и липидным профилем у 243 здоровых детей, не страдающих ожирением [5]. Исследованные были разделены на 2 группы: на группу с дефицитом витамина D $(<20$ нг/мл) и на группу с нормальным содержанием витамина D (>20 нг/мл). Группа с дефицитом данного витамина показала более высокий уровень триглицеридов $(90,27$ против 74,74 ммоль). Исследователи пришли к выводу, что уровень витамина D, по видимому, влияет на липидный профиль даже не страдающих ожирением детей. B другое исследование вошли больные с ранней диабетической нефропатией и с дефицитом витамина $\mathrm{D}$, которые ежемесячно получали $50000 \mathrm{ME}$ витамина D внутримышечно в течение 6 месяцев. В результате терапии витамином D значительно снизились величины ДАД, общего холестерина, атерогенных липопротеидов низкой плотности [7].

У исследованных нами больных с АГ при низких значениях содержания витамина D в крови ( $<30$ нг/мл) наблюдаются более высокие концентрации атерогенных и низкие концентрации антиатерогенных липопротеидов, по сравнению с пациентами с оптимальным уровнем витамина D и здоровыми добровольцами. Так, уровень атерогенных ЛПНП и ЛПОНП у больных I группы, был, соответственно, на $20,9 \%, p<0,05$ и на 50,2\%, p<0,001выше, чем у пациентов II группы, и на 29,9\%, p<0,01 и на $57,6 \%, \mathrm{p}<0,001$ больше, чем в группе контроля. Кроме того, в 1-ой группе наблюдались более высокие концентрации ТГ - соответственно, на 32,4\% и на 34,1\%, $\mathrm{p}<0,01$, по сравнению с больными с оптимальным уровнем витамина $\mathrm{D}$ и здоровыми добровольцами. В величинах уровня антиатерогенных ЛПВП существенной достоверной разницы между больными 1-ой и 2-ой групп не было обнаружено. Лишь у больных с низким уровнем витамина D значения ЛПВП были 21,7\%, p $<0,05$ ниже, чем в контрольной группе. В результате вышеописанных изменений уровень ОХС у пациентов с низким уровнем витамина D оказался достоверно выше, чем в других сравниваемых группах $(\mathrm{P}<0,05)$. Аналогичные данные получены в исследованиях других авторов, среди которых особое внимание привлекает проведенное в 2019 году исследование по влиянию витамина D на показатели липидного спектра крови [6], в котором величины ЛПНП и ТГ при недостаточности данного витамина были выше на $61,4 \%$ и на 45,9\%, а уровень ЛПВП был ниже на 27,0\%, по сравнению с пациентами с нормальными значениями витамина D. Авторы приходят к выводу, что дислипидемия может быть результатом недостаточности или дефицита витамина D. Другие авторы отмечают, что дефицит витамина D является независимым предиктором повышения уровня триглицеридов [8]. Исходя из полученных данных можно предположить, что витамин D вносит свой вклад в поддержание антиатерогенного потенциала плазмы у больных с АГ за счет регулирования иммунной воспалительной реакции в интиме сосудов и ингибирования пролиферации гладкомышечных клеток сосудов.

Заключение. Таким образом, низкий уровень витамина D у больных с АГ ассоциируется с усилением процессов атерогенеза.

$$
\text { *** }
$$

1. Skaaby T, Thuesen BH, Linneberg A. Vitamin D, Cardiovascular Disease and Risk Factors. Adv Exp Med Biol. 2017; 996: 221-230. https://doi.org/ 10.1007/978-3-319-56017-5_18

2. Alkippi N, Marina T, Nikolaos M, Anargyros M, Anastassios P, and Michael K. Vitamin D in cardiovascular disease, In Vivo September-October 2018 vol. 32 no. 5 977-981. https://doi.org/ 10.21873/invivo. 11338

3. Antonio JL, Jamerson RC, Maria LGR, Diego BCB. Vitamin D Deficiency and Cardiovascular Diseases, Int. J. Cardiovasc. Sci. vol.31 no.4 Rio de Janeiro July/Aug. 2018 Epub May 21, 2018, http://dx.doi.org/10.5935/2359-4802.20180025

4. Jorde R, Grimnes G. Vitamin D and metabolic health with special reference to the effect of vitamin D on serum lipids. Prog Lipid Res. 2011; 50(4): 303-312. https://doi.org/ 10.1016/j.plipres.2011.05.001. [PubMed] [Cross Ref]

5. Mi Ra Kim and Su Jin Jeong *.Relationship between Vitamin D Level and Lipid Profile in Non-Obese Children. Metabolites 2019, 9, 125; https://doi.org/ 10.3390/metabo9070125 
6. Nabil Ahmad Bashir1, Adnan Ahmad Mohammad Bashir, Hani Adnan Bashir Effect of Vitamin D deficiency on Lipid Profile. American Journal of Laboratory Medicine 2019; 4(1): 11-18 https://doi.org/ 10.11648/j.ajlm.20190401.12

7. Liyanage GC1, Lekamwasam S2, Weerarathna TP2, Liyanage CE3 Effects of high-dose parenteral vitamin D therapy on lipid profile and blood pressure in patients with diabetic nephropathy: A randomized double-blind clinical trial. Diabetes Metab Syndr. 2017 Dec; 11 Suppl 2: S767-S770. https://doi.org/ 10.1016/j.dsx.2017.05.013. Epub 2017 Jun 3.

8. Rodriguez-Rodriguez E., Ortega R.M., Gonzalez-Rodriguez L.G., Lopez-Sobaler A.M. for UCM Research Group VALORNUT. Vitamin D deficiency is an independent predictor of elevated triglycerides in Spanish school children. Eur J Nutr 2011; 50(5):373-8. https://doi.org/ 10.1007/s00394-010-0145-4 


\title{
SECTION II. PEDAGOGY
}

\author{
Белисова А.А. \\ Коррекционно-педагогические приемы и средства по формированию \\ познавательной активности у детей младшего школьного возраста с ЗПР
}

doi $10.18411 / g q-15-10-2021-03$

\section{Аннотация}

В данной статье рассмотрено понятие познавательной активности, отражены особенности построения образовательных программ для детей младшего школьного возраста с задержкой психического развития, показаны основные коррекционнопедагогические приемы и средства, которые можно использовать в работе со школьниками с задержкой психического развития.

Ключевые слова: познавательная активность, задержка психического развития, коррекционно-педагогические приемы, коррекционно-педагогические средства, школьники с ЗПР.

\section{Abstract}

This article discusses the concept of cognitive activity, reflects the features of building educational programs for primary school children with mental retardation, shows the main correctional and pedagogical techniques and tools that can be used in working with schoolchildren with mental retardation.

Keywords: cognitive activity, mental retardation, correctional and pedagogical techniques, correctional and pedagogical means, schoolchildren with ZPR.

Активность - это особый вид деятельности, характеризующийся усилением основных своих характеристик (целенаправленности, мотивации, осознанности, владения способами и приёмами действий, эмоциональности). Познавательная активность является одним из видов активности личности. Развитие этой деятельности влияет на формирование отношения к действию, постоянное состояние готовности к нему, усвоение социального опыта, накопление знания, способов действия, навыков и умений, уже ранее приобретённых человечеством. Это то, без чего действие не будет успешным. Без определенного уровня развития познавательной активности ребенок младшего школьного возраста не сможет освоить многие предметы, что отрицательно скажется не только на успеваемость в школе, но и на его личности.

Для успешной реализации образовательных и педагогических задач и, в частности, для формирования познавательной активности у детей младшего школьного возраста с задержкой психического развития важнейшее значение имеют два элемента, от качества разработки которых напрямую зависит эффективность образовательного процесса: образовательная программа и непосредственно методические приемы и средства, применяемые педагогами на занятиях.

В силу особенностей развития детей с задержкой психического развития (нарушение нормального темпа психического развития, проявляющееся, прежде всего, в медленном формировании отдельных психических функций), специфика обучения данных школьников в общеобразовательных учреждениях должна обеспечиваться реализацией адаптированной индивидуальной образовательной программы, которая разрабатывается с учетом физических, психических, личностных и иных особенностей учащегося. Обязательным компонентом этой программы является т.н. «коррекционный компонент», представляющий собой коррекционную и развивающую работу, 
направленную на формирование познавательной активности. Именно развитие и коррекция познавательных процессов является необходимым условием преодоления трудностей, возникающих в учебном процессе, и устранения недостатков в психическом развитии детей с задержкой психического развития (Золоткова Е.В.) [1].

Соответствующая вышеперечисленным требованиям программа должна предусматривать воплощение следующих направлений:

способствование формированию психологических предпосылок овладения учебной деятельностью, то есть таким психологическим умениям и качествам, без которых эффективная учебная деятельность не может проходить (умение слушать и слышать учителя; умение копировать образец, заданный как в наглядной, так и в словесной формах; умение учитывать в своей работе заданную систему условий и так далее);

- развитие познавательной активности;

способствование формированию психологических новообразований младшего школьного возраста (произвольности в управлении не только двигательными, но и, прежде всего, интеллектуальными процессами - вниманием, восприятием, научиться произвольно запоминать, умение выполнять задания в интеллектуальном плане без опоры и реального манипулирования объектами).

Программа должна содержать три основополагающих компонента: диагностический, коррекционный и рефлексивный. Цель диагностического компонента - исследование уровня сформированности познавательных процессов учащегося (мышление, память, внимание), общего вектора психологической коррекции (выявление индивидуально-типологических проявлений нарушений). Коррекционный компонент обеспечивает использование совокупности средств и условий, предназначенных для устранения недостатков в познавательной сфере у детей младшего школьного возраста с задержкой психического развития и осуществления полноценного и своевременного личностного развития, обеспечения эмоционального благополучия при помощи интеграции содержания образования и организации взаимодействия его субъектов, а также для предупреждения потенциальных трудностей усвоения программы классической школы, обусловленных недоразвитием познавательной сферы младших школьников. Рефлексивный компонент служит для определения уровня эффективности коррекционно-педагогического воздействия и должен быть нацелен на измерение динамики развития учащегося.

Коррекционно-педагогическая работа по формированию познавательной активности у детей младшего школьного возраста с задержкой психического развития может быть организована и включена в контекст основной программы.

Немаловажным аспектом формирования познавательной активности у детей младшего школьного возраста с задержкой психического развития являются непосредственно методические приемы и средства, используемые на уроках. Специалисты выделяют следующие методические приемы и средства.

1) Средства изобразительной деятельности. Цель занятий с использованием рисования: формирование самостоятельности, познавательной активности, инициативности, развитие творческих способностей учащихся. В процессе рисования учащиеся знакомятся с проявлениями человеческих чувств, знаково-символической системой координат. Грамотно организованная изобразительная деятельность влияет на формирование эмоционального компонента познавательной активности, становление социальной компетентности и личностных качеств. 
2) Дидактическая игра - является активной формой учебной деятельности, направленной на имитационное моделирование изучаемых явлений, систем, процессов. Дидактические игры используются в обучающих целях. Этой формой учебной деятельности возможно добиться более осознанных и прочных умений, навыков и знаний. Отличительная черта дидактических игр - наличие игровой ситуации, которая используется в качестве базы метода. Деятельность участников в игре регламентирована: строгая система оценивания, имеются правила и порядок действий.

3) Рекомендуется активно в совместной работе с детьми использовать мультимедийные презентации и компьютерные игры, которые позволяют создать проблемную ситуацию к последующему рассмотрению дальнейших путей познания того или иного объекта и установлению причинно-следственных связей. Например, предложить детям посмотреть видео, в котором ребенок ест снег, и порассуждать, к чему это может привести и как следует в дальнейшем поступить ребенку.

4) Создание и наполнение в классе мини-библиотеки - детские книги, которые ребята могут приносить из дома. Школьники могут читать и комментировать произведения. Это хороший метод познавательного и речевого развития детей с ЗПР.

5) В развитии мышления, речевого высказывания рекомендуется использовать метод дидактического синквейна, который предполагает создание условий для развития личности, способной критически мыслить, т.е. исключать лишнее и выделять главное, обобщать, классифицировать, составлять речевое высказывание по плану. Следует учить составлять школьников дидактические синквейны в форме игры. Данный прием не требует особых условий для применения и органично вписывается в работу по развитию речи.

6) Работа с родителями является одним из основополагающих факторов комплексного подхода к образовательно-коррекционному процессу. Эффективность данной работы основана на индивидуальном, личностно-ориентированном подходе при обязательном учете индивидуальных запросов семьи и проблем обучения и развития учащегося (Тельнова Ж.Н.) [2].

Таким образом, можно сказать, что учебно-коррекционная программа для детей младшего школьного возраста с задержкой психического развития должна быть составлена в соответствии с современным уровнем развития психолого-педагогической науки с учетом практического опыта педагогов-практиков и должна содержать три компонента: диагностический, коррекционный, рефлексивный. Основываясь на работах исследователей и практическом опыте практиков, можно определить основные методические приемы и средства для формирования познавательной активности у детей младшего школьного возраста с задержкой психического развития: дидактическая игра, средства изобразительной деятельности, мультимедийные презентации и компьютерные игры, создание мини-библиотек, использование синквейнов, работа с родителями.

1. Золоткова, Е. В. Особенности развития познавательных процессов у младших школьников с ЗПР / Е. В. Золоткова, Е. В. Тюрина // Современный взгляд на будущее науки: сборник статей по итогам Международной научно-практической конференции; под ред. Р. Г. Юсупова, А. С. Ванесян, С. А. Калужина [и др.]. - Стерлитамак: АМИ, 2017. - 175 с.

2. Тельнова Ж. Н. Развитие познавательной активности детей старшего дошкольного и младшего школьного возраста в разных формах и методах обучения. Дисс. канд. пед. наук. — Омск, 1997. 
Дудар Т.Е., Уляшева Л.Г.

Личность как результат образовательного процесса: действующие парадигмы и вектор их развития

ФГБОУ ВО «СГУ им. Питирима Сорокина»

(Россия, Ськтывкар)

doi 10.18411/gq-15-10-2021-04

\section{Аннотация}

Современные условия жизни и динамично меняющаяся действительность окружающего мира вносят коррективы в требования общества к системе образования, которая издавна занимается формированием личности человека. Однако в настоящее время основной характеристикой состояния теоретического знания об образовании является его полипарадигмальность. Поэтому в данной работе поставлена цель оценить действующую множественность парадигм на предмет востребованности каждой из них сложившимися реалиями человеческой жизни в 21 веке. Исследование было проведено с помощью анализа каждого концептуального подхода и обобщения его влияния на формируемый тип личности как результат образовательного процесса. Заключением исследования является вывод о том, что востребованная временем личность будет формироваться, если образовательный процесс построить на системе сильных сторон, заимствованных из всей совокупности имеющихся парадигм.

Ключевые слова: личность, парадигма, система образования, требования общества, результат образования.

\section{Abstract}

Modern living conditions and the dynamically changing reality of the world around them make adjustments to the requirements of society for the education system, which has long been involved in the formation of a person's personality. However, at present, the main characteristic of the state of theoretical knowledge about education is its polyparadigmality. Therefore, in this work, the goal is set - to assess the current multiplicity of paradigms for the relevance of each of them by the prevailing realities of human life in the XXI century. The study was carried out by analyzing each conceptual approach and generalizing its influence on the formed personality type as a result of the educational process. The conclusion of the study is the inference that a personality demanded by time will be formed if the educational process is built on a system of strengths borrowed from the entire set of existing paradigms.

Keywords: personality, paradigm, education system, society requirements, education result.

Современный динамично меняющийся мир характеризуется значительным увеличением информационного потока, усложнением и необходимостью совершенствования социальных и экономических отношений, внедрением во все сферы взаимодействия бизнеса, социума и природы результатов научно - технического прогресса. Указанные условия меняют требования общества к системе образования, назначение которой всегда заключалось в формировании востребованной временем личности человека. Поэтому для выбора вектора ее развития усилия многих исследователей направлены в настоящий период на выявление того идеального образа индивида, который бы соответствовал заявляемым ожиданиям.

По мнению Е.М. Ибрагимовой и Т.М. Андриановой, «основополагающим требованием общества к современной системе образования является формирование личности, которая умела бы самостоятельно творчески решать научные, производственные, общественные задачи, критически мыслить, вырабатывать и защищать свою точку зрения, свои убеждения, систематически и непрерывно 
пополнять и обновлять свои знания путем самообразования, совершенствовать умения, творчески применять их в действительности» [4].

Н.В. Костромина указывает, что вызовы социального, культурного и экономического развития РФ на современном этапе «обуславливают возрастание требований к профессиональной подготовке будущих специалистов» [6].

Т.Г. Белобородова считает, что «одной из важнейших задач современного высшего образования является формирование творческой личности специалиста, способного к саморазвитию, самообразованию, инновационной деятельности в условиях быстрого изменения многих сторон общественной жизни», который в достаточной степени владеет информационно-коммуникационными технологиями и способен критически мыслить [2].

Приведенные высказывания позволяют сделать вывод, что трансляция общественных запросов происходит на все уровни образования. В связи с этим особую актуальность приобретает вопрос обновления и разработки основы современного концептуального подхода к организации целостного педагогического процесса как ответа на предъявляемые вызовы изменившейся действительности.

Следует отметить, что проблемы определения, обоснования и утверждения новой парадигмы образования являются весьма обсуждаемыми в российском педагогическом сообществе уже достаточно продолжительное время. В научных публикациях многими авторами предпринимаются попытки оценить имеющийся для удовлетворения современных запросов общества потенциал разработанных концептуальных взглядов, а также выяснить направление дальнейшего развития и представить основу для оформления его оптимального решения. Анализ проводимых в этой области исследований показывает, что в круге обсуждаемых вопросов оказываются как отдельные парадигмальные установки, так и некоторая их совокупность в сравнении друг с другом. Авторы единодушны в признании полипарадигмальности современного состояния теоретического знания об образовании, а также необходимости переосмысления имеющихся разработок и выработки единой парадигмы, отвечающей новым социально-экономическим вызовам. В связи с обозначенной актуальностью исследуемой темы в данной работе была поставлена цель - оценить действующую множественность парадигм на предмет востребованности каждой из них сложившимися реалиями человеческой жизни в 21 веке, чтобы на основе выявленной полезности их сущностных установок определить направление перспективного движения для формирования необходимого типа личности как конечного результата образования.

В первую очередь следует отметить, что в работах различных авторов присутствует различное представление о количестве и названиях исходных парадигм:

1. «знаниевая» и компетентностная парадигмы [7];

2. «знаниево - ориентированная» и «личностно - ориентированная» парадигмы, наиболее действенный вариант которых представляет собой «компетентностно-ориентированное» образование [1];

3. «три основных способа бытия в реалиях обучения - воспитания: научно - технократическая парадигма, гуманитарная и эзотерическая» $[5$, c. 15$]$;

4. традиционалистско-консервативная,

гуманистическая, бихевиористско-рационалистическая, эзотерическая, сциентистская, личностная, культурологическая и компетентностная парадигмы [10].

Второй выявленной тенденцией можно считать отсутствие единого мнения у исследователей относительно основы новой требуемой временем парадигмы: некоторые считают, что это должен быть компетентностный [5], [8] или личностно ориентированный [1], [9] подход, другие обосновывают необходимость создания новейших совершенно инновационных подходов, основанных на изменении картины 
мира [7]. При этом если одними исследователями допускается парадигмальная преемственность и взаимное соприкосновение [7], [10], то, по мнению других, выход из кризиса на основе компромисса невозможен [3].

Со своей стороны считаем, что для обозначения дальнейших ориентиров целесообразно опираться на исторически наработанный полезный опыт и на его основе определить, какие сильные стороны разработанных концептуальных идей смогли бы выступить базой для создания необходимой парадигмы образования.

Проведенный анализ показал, что достоинством «знаниевой» парадигмы, безусловно востребованной в условиях современности, является создание базиса для любого обучения, в том числе и для дальнейшей профессиональной подготовки. Преимуществом компетентностной парадигмы служит практикоориентированность образования, усиление его связи с реальными условиями жизни и профессиональной деятельности, раскрытие творческих способностей личности, то есть формирование у обучающегося опыта самостоятельного решения различных проблем. Плюсом гуманистической парадигмы общепризнанно считается ориентация на индивидуальность обучающегося, учет его внутреннего мира и обмен духовными ценностями, позволяющими организовать безопасное взаимодействие в жизненной среде. Положительным моментом рационалистической парадигмы считается прагматизм и запрограммированность действий для приспособления и выживания в постоянно меняющихся условиях. Достоинством эзотерической парадигмы следует считать развитие духовных сил. Сильной стороной сциентистской парадигмы, существенно дополняющей «знаниевую», можно признать передачу для освоения лишь точного, выверенного наукой знания. Большим преимуществом личностной парадигмы является эмоциональное и социальное развитие обучающегося. Ценностью культурологической парадигмы можно считать ее непротиворечивость со «знаниевой» парадигмой в создании целостного восприятия окружающего мира.

Полагаем, что результатом образовательного процесса, построенного в будущем на системе сильных сторон, заимствованных из всей совокупности имеющихся парадигм, будет получаться именно такой тип личности, который наиболее полно отвечает современным экологическим, информационным, социальным и экономическим вызовам динамично меняющейся реальности. Он будет обладать некоторой базой научных знаний, уметь их применить на практике безопасно для всего окружающего либо с помощью какого-то приобретенного алгоритма действий, либо с помощью проекта, выстроенного на основе своих развитых творческих способностей. Если собственного «багажа» будет недостаточно, то такая личность, обученная и воспитанная с помощью новой парадигмы, будет способна найти информацию, воспринять ее и использовать ее нравственным способом. А для этого сформированная по новой парадигме личность должна являть собой эмоционально целостный и духовно-богатый индивид, получивший полноценное экологическое и валеологическое воспитание.

$$
* * *
$$

1. Арасланова А.А. Кризис классического образования в эпоху смены педагогических парадигм // Вестник Челябинского государственного педагогического университета. 2010. № 3. С. 14 - 23.

2. Белобородова Т.Г. Организация самостоятельной работы студентов с использованием дистанционных образовательных технологий // Новые образовательные технологии в вузе. Сборник тезисов докладов участников конференции. 2014. С. 138 - 147.

3. Герасимов Г.И. Парадигмальный плюрализм как проявление кризиса образования // Теория и практика общественного развития. 2009. № 3 - 4. С. 7 - 21.

4. Ибрагимова Е.М., Андрианова Т.М. К вопросу о сущности понятия «Самостоятельная работа» // Казанский педагогический журнал. 2013. № 5 (100). С. 54 - 58.

5. Коваль Н.А., Солянкина Л.Е. Компетентностный подход как методологическая основа новой парадигмы образования в России //Вестник Воронежского государственного технического университета. 2013. Т.9. № 3 - 2. С. $157-159$. 
6. Костромина Н.В. Педагогические технологии обучения: сущность, их характеристики и эффективность // Сибирский педагогический журнал. 2007. № 12. С. 105 - 111.

7. Крежевских О.В. Компетентность или мировоззрение: к вопросу о парадигме современного образования // Вестник Шадринского государственного педагогического университета. 2015. № 3 (27). C. $23-27$.

8. Налиткина О.В. Компетентностный подход как основа новой парадигмы образования // Известия Российского государственного педагогического университета им. А.И. Герцена. 2009. № 94. С. 170 $-174$.

9. Смолеусова Т.В. Концепция личностно - ориентированного образования на основе проявления личности // Вестник Новосибирского государственного педагогического университета. 2016. № 6 (34). C. $7-16$.

10. Яцык В.З., Чернышенко Ю.К., Писарева О.В. Парадигмы современного образования // Физическая культура, спорт - наука и практика. 2008. № 2. С. $47-51$.

\section{Егошина Н.Г. \\ Роль этнокультурных ценностей в жизни современных студентов}

ФГ БОУ ВО «Поволжский государственный технологический университет» (Россия, Йошкар-Ола)

doi $10.18411 / g q-15-10-2021-05$

\section{Аннотация}

В статье рассматриваются этнокультурные ценности

как явления традиционно-бытовой культуры, служащие для сплочения этноса и представленные либо в виде предметных ценностей, либо как ценности национального сознания. В статье приводятся этапы исследования по выявлению уровня этнической самоидентичности студентов и степени их приобщенности к этнокультурному наследию своего народа. Автором приведены данные диагностики студентов, которые выявляют отношение молодежи к основным компонентам этнокультуры, а также степень реализации этнокультурных традиций в повседневной жизни.

Ключевые слова: ценность, этнос, этническая самоидентификация, этнокультура, этнокультурная ценность, культурное наследие, образование.

В современном мире, подверженном многочисленным вызовам и рискам, актуализируется проблема развития профессиональной компетенции будущих специалистов в контексте реализации ценностного подхода и на его основе воспитания позитивных ценностных установок студентов. Совершенно очевидно, что человечество сможет выжить, лишь поставив в центр своего существования высшие или абсолютные ценности. Именно сегодняшние студенты будут определять, какие ценностные ориентиры будут положены в основу осмысления будущего России. Поэтому, по мнению многих авторов, «аксиологический подход оформился как ведущий методологический подход в педагогической науке» [7, с. 28]. Следует подчеркнуть, что образование - основной канал целенаправленного внесения в сознание главных ценностей. Согласимся с мнением, что образование в перспективе должно отобрать у конкурирующих политических партий функцию приобщения ребенка к общечеловеческим ценностям, аксиологическую ценностную функцию в обществе [4, с. 93].

В своем исследовании мы остановились на роли этнокультурных ценностей в жизни современного студенчества. В анкетировании участвовали 54 человека студентов возрасте 19-22 лет технических направлений подготовки ФГБОУ ВО «Поволжский государственный технологический университет». Исследование восприятия этнической культуры мы начали с методики «Недописанный тезис», предложив студентам ответить, к какому этносу они себя относят [Таблица 1], а также определить, что такое этнос как таковой и каковы его структурные составляющие [Таблица 2]. 
Таблииа 1

Этническая самоидентификачия

\begin{tabular}{|c|c|c|}
\hline Название этноса & Количество, чел. & Количество, $\%$ \\
\hline 1. Русский & 23 & 43,3 \\
\hline 2. Мари & 15 & 28,3 \\
\hline 3. Татарский & 1 & 1,9 \\
\hline 4. Чуватский & 1 & 1,9 \\
\hline 5. Таджсикский & 2 & 3,8 \\
\hline 6. Кыргызский & 2 & 3,8 \\
\hline 7. Узбекский & 3 & 5,6 \\
\hline 9. Азербайджанский & 1 & 1.9 \\
\hline 10. Сметанный (назвали два и более сразу) & 4 & 7,6 \\
\hline 11. Не смогли отнести себл ни к какому этносу & 1 & 1,9 \\
\hline Всего & 54 & 100 \\
\hline
\end{tabular}

При анализе данных мы исходили из классического определения этноса, которое было дано в трудах Ю.В. Бромлея. Этнос может быть определен «как исторически сложившаяся на определенной территории устойчивая совокупность людей, обладающих общими относительно стабильными особенностями языка и культуры, а также сознанием своего единства и отличия от других подобных образований (самосознанием), фиксированным в само названии (этнониме)» [10, с. 7].

Таблица 2

Структурные составляющие понятия «Этнос»

\begin{tabular}{|c|c|}
\hline Название составляющей & $\begin{array}{c}\text { Количество студентов, отметивиихх } \\
\text { данный признак, \% }\end{array}$ \\
\hline 1. Общность территории & 100 \\
\hline 2. Общий язык & 98,1 \\
\hline 3. Общая культура & 100 \\
\hline 4. Самосознание & 15 \\
\hline
\end{tabular}

Первый элемент понятия «этнос» - общность территории - был отмечен всеми студентами (100\% респондентов), но лексически эта мысль была выражена поразному: «общее место проживания», «одна Родина», «один родной край» и пр. Хотя многие исследователи отмечают, что образ малой Родины стирается из сознания молодых людей, особенно городских жителей и студенческой молодежи угрожает кризис идентичности, который проявляется в «нивелировании значимости национальной и региональной идентичности» [7, с. 115], мы видим, что это, к счастью, не всегда так. Читая творческие работы - сочинения «Какие ассоциации вызывает у Вас словосочетание «Родная земля», мы с радостью отметили, что многие респонденты дали очень проникновенные, эмоционально-наполненные ответы: «любимые родители», «отчий дом», «очень теплые ощущения», «большие просторы», «это родина, где я родился, вырос», «это родина, которая дала мне мирное небо над головой», «это знакомые улицы, районы, где мы выросли, играли с друзьями». Особенно часто такие эмоционально-окрашенные ответы встречались у студентовиностранцев (студентов из ближнего и дальнего зарубежья), которые очевидно сильно скучают по своей Родине.

Второй структурный признак - общий язык или нащиональный язык - тоже выделили практически все студенты (98,1\% участвовавших в опросе). Выяснилось, что говоря о языке своего этноса, 36 человек $(67,9 \%)$ знают родной язык (для сравнения: все студенты-иностранцы знают родной язык и говорят на нем), 14 человек $(26,4 \%)$ сказали, что не знают родного языка. Из числа последних 10 человек $(71,4 \%$ респондентов) заявили, что не знают родного языка и не нуждаются в нем, не хотят на нем разговаривать. Лишь 4 человека $(28,6 \%)$ пожалели, что не знают родного языка и изъявили желание его выучить. Очевидно, это связано с тем, что, несмотря на тот факт, 
что марийский язык является государственным языком республики Марий Эл, в городе студенты чаще сталкиваются с русскоговорящей средой в повседневной жизни. Всего 8 студентов (15\%), давая определение этноса, вспомнили о национальном или этническом самосознании, подчеркнули необходимость единения, чувства солидарности, осознании своей уникальности, отличия от других этносов.

Остановимся более подробно на таком признаке этноса, как этнокультура, который тоже указали 100\% респондентов. Как любая культура, этнокультура включает в себя ценности, нормы поведения и язык как форму их передачи, конкретные артефакты (предметы материальной культуры). Ценности и нормы выражаются в традициях, обрядах, ритуалах, устном народном творчестве, в религиозных верованиях, этикете. Ряд исследователей полагает, что именно ценности являются основным компонентом культуры [8]. Они вводят понятие «этнокультурные ценности».

Некоторые исследователи проводят отличие между этнической культурой и культурой этноса. Под культурой этноса понимается вся «совокупность культурного достояния, присущая данному этносу, в лице его отдельных представителей, локальных групп и т.п., независимо от того, имеют ли различные элементы и структуры этого достояния специфическую этническую окраску или же являются этнически нейтральными» [1]. Под этнической культурой понимается «совокупность лишь тех культур, элементов и структур, которые обладают этнической спецификой», иными словами выполняют этнодифференцирующую функцию в рамках оппозиции «мы - не мы» [2, с. 31]. Оговоримся, что в нашем исследовании у студентов смешались эти понятия, т.е. они оба вошли в структуру этнокультуры [Таблица 3].

Таблица 3

Компоненты этнической культуры

\begin{tabular}{|c|c|c|}
\hline Название компонента & $\begin{array}{l}\text { Количество респондентов, } \\
\text { указавших данный признак } \\
\text { (чел.) }\end{array}$ & $\begin{array}{c}\text { Количество респондентов, } \\
\text { указавших данныій признак } \\
(\%)\end{array}$ \\
\hline \multicolumn{3}{|l|}{ Духовная культура: } \\
\hline 1. Начиональные праздники & 44 & 83 \\
\hline 2. Традичии, обряды, обычаи & 28 & 52,8 \\
\hline 3. Религиозные верования & 23 & 43,4 \\
\hline 4. Народные игры & 22 & 41,5 \\
\hline 5. Устное литературное творчество & 17 & 32 \\
\hline 6. Народные песни & 13 & 24,5 \\
\hline 7. Этикет, нормы поведения & 11 & 20,7 \\
\hline 8. Народные танцы & 9 & 16,9 \\
\hline \multicolumn{3}{|l|}{ Материальная культура: } \\
\hline 1. Национальная еда & 47 & 88,7 \\
\hline 2. Одежда, национальный костюм & 28 & 52,8 \\
\hline 3. Факты из истории & 21 & 39,6 \\
\hline 4. Природные объекты & 19 & 38,2 \\
\hline 5. Ремесла, промысльь & 16 & 30,2 \\
\hline $\begin{array}{c}\text { 6. Памятники, архитектурные } \\
\text { сооружения }\end{array}$ & 13 & 24,5 \\
\hline 7. Орудия труда & 1 & 1,9 \\
\hline \multicolumn{3}{|l|}{ Люди - символы культуры: } \\
\hline 1. Писатели, поэты & 35 & 66 \\
\hline 2. Герои войн, исторические личности & 24 & 45,3 \\
\hline 3. Литературные герои & 21 & 39,6 \\
\hline 4. Музыканты, певиы, композиторы & 20 & 37,7 \\
\hline 5. Актеры театра и кино & 9 & 16,9 \\
\hline 6. Государственные деятели & 5 & 9,4 \\
\hline 7. Ученые & 4 & 7,6 \\
\hline 8. Спортсмены & 1 & 1,9 \\
\hline
\end{tabular}


Исходя из таблицы видно, что студенты достаточно полно воспроизвели понятие этнокультуры и ее составляющих, отразив материальную, духовную культуру, а так же людей как творцов или трансляторов этнической культуры. Очевидно, что «представители этноса ориентируются на характерные, устоявшиеся для их общности этнокультурные ценности, определяют цели, смысл своего существования, соотносят с ними свои действия, согласуют формы поведения, осуществляют выбор жизненной стратегии» [3, с. 43]. Поэтому следующим этапом нашего исследования стала задача определить отношение студентов к выделенным компонентам этнокультуры как к смыслообразующим и жизненно важным понятиям. С этой целью студентам предлагалось ответить на ряд вопросов. Приведем некоторые из них в качестве иллюстрации [Таблица 4].

Таблицุа 4

Отночение к некоторым элементам этнокультуры

\begin{tabular}{|c|c|c|c|}
\hline \multicolumn{4}{|c|}{ 1. Нужно ли отмечать свои национальные праздники? (\%) } \\
\hline Да, это важно & Да, для оригинальности & $\mathrm{Hem}$ & Затрудняюсь ответить \\
\hline 32,7 & 16,9 & 39,6 & 11,3 \\
\hline \multicolumn{4}{|c|}{ 2. Нужнно ли соблюдать традичионные обряды своего народа в семье? } \\
\hline 13,2 & 9,4 & 62,3 & 15,1 \\
\hline \multicolumn{4}{|c|}{ 3. Нужно ли носить национальную одежду? } \\
\hline 0 & 11,4 & 79,2 & 9,4 \\
\hline \multicolumn{4}{|c|}{ 4. Нужнно ли готовить / покупать блюда национальной кухни? } \\
\hline 16,9 & 37,7 & 37,7 & 7,7 \\
\hline \multicolumn{4}{|c|}{ 5. Нужно ли знать и петь песни своего народа? } \\
\hline 9,4 & 30,3 & 50,9 & 9,4 \\
\hline
\end{tabular}

Как видно из приведенных данных, большинство студентов отвергают необходимость соблюдения этнокультурных традиций в быту. По всей видимости, это объясняется укладом жизни современной семьи, где дети не видят представителей старшего поколения в национальной одежде, родителям некогда заниматься приготовлением национальной еды, а народные песни и танцы являются атрибутами праздников только в глубинке. Иное отношение к праздникам, так как они дают возможность отдыха и веселого времяпрепровождения. Обнаружив такое негативное отношение к указанным компонентам этнокультуры, мы уже заранее могли предположить результаты последней стадии исследования, где мы хотели узнать, соблюдают ли студенты в своей семье в практике повседневной жизни традиции своего народа. Оказалось, что наши предположения были верными [Таблица 5].

Таблииа 5

Реализация этнокультурных традищий на практике

\begin{tabular}{|c|c|c|c|}
\hline \multicolumn{4}{|c|}{ 1.Отмечаете ли Вы национальные праздники своего народа? (\%) } \\
\hline Да, это важно & Да, для оригинальности & Нет & Затрудняюсь ответить \\
\hline 22,6 & 58,5 & 18,9 & 0 \\
\hline \multicolumn{4}{|c|}{ 2. Соблюдаете ли Вы традичионные обряды своего народа в семье? } \\
\hline 11,1 & 41,4 & 32,6 & 15 \\
\hline \multicolumn{4}{|c|}{ 3. Поете ли Вы песни своего народа в семье? } \\
\hline 11,1 & 41,4 & 32,6 & 15 \\
\hline \multicolumn{4}{|c|}{ 4. Играете ли Вы в народные игры в семье? } \\
\hline 0 & 11,3 & 86,7 & 3,8 \\
\hline \multicolumn{4}{|c|}{ 5.Занимаетесь ли Вы (или кто-то в семье) народными ремеслами? } \\
\hline 3,8 & 16,9 & 75,5 & 3,8 \\
\hline
\end{tabular}

Опрос подтвердил, что около половины респондентов лишь иногда на практике выполняют действия, так или иначе связанные с этнокультурными традициями, в основном это связано с национальными праздниками. Очень большая доля студентов (более $70 \%$ ) никогда в семье не поют народные песни, не играют в народные игры, не пробовали свои силы в народных ремеслах, декоративно-прикладном искусстве. 
Опираясь на данные, полученные в ходе исследования, можно утверждать, что современная молодежь хорошо информирована, обладает довольно обширными знаниями о содержании культуры своего этноса, однако гуманистический потенциал этнокультуры остается нереализованным в практике повседневной жизни. Это должно хоть в какой-то степени быть восполнено возможностями современного образовательного процесса в школе и вузе [5, 6]. На наш взгляд, необходим поиск таких решений в сфере образования, которые позволили бы обеспечить сохранность культурных ценностей каждого этноса, так как именно этнокультурное наследие - это то, что позволяет сохранить принадлежность человека к определенному социокультурному пространству и обеспечивает чувство малой Родины.

$$
* * *
$$

1. Арутюнов, С.А. Культурная антропология. - М., 2004. - 216 с.

2. Арутюнов, С.А. Инновации в культуре этноса и их социально-экономическая обусловленность // Этнографические исследования развития культуры. - М.: Наука, 1985. - С.31 - 49.

3. Богдасарова, А.Б. Инкорпорация этнокультурных ценностей в контекст современного образовательного процесса // Социально-гуманитарные знания. - 2007. - № 6. - С. 42 - 51 .

4. Вязникова, Л.Ф. Ценности в образовании: выбор пути развития // Психологическая наука и образование. - 2002. - № 4. - С. 88-98.

5. Егошина Н. Г. Этнокультурные ценности как основа аксиологизации современного образования // Научное мнение: научный журнал / Санкт-Петербургский университетский кон $\neg$ сорциум. — СПб., 2020. 一 № 6. - С. 47 - 51.

6. Егошина, Н.Г. Этнокультурное образование в Республике Марий Эл: опыт, сложности, перспективы// Языки и литературы в поликультурном пространстве: современное состояние и перспективы развития: сборник материалов Международной научно-практической конференции. Уфа: РИЦ БашГУ, 2020. - С.159 - 166.

7. Кирьякова, А.В. Ценностные ориентиры университетского образования/ А.В. Кирьякова// Вестник ОГУ. - 2011. - №2 (121). - С. 27 - 33.

8. Магранов, А.С., Деточенко, Л.С. Граждансая идентичность современной студенческой молодежи: особенности и факторы трансформации// Социологичсекие исследования. - 2018. - №8. - С. 108 106.

9. Першиц, А.И. Возможен ли информационный подход к социальным ценностям этнической культуры? // Этнографические исследования развития культуры. - М.: Наука, 1985. - С. 50 - 63.

10. Этнические процессы в современном мире /под ред Ю.В. Бромлей. - М.: Наука, 1987. - 445 с.

\section{Захарова Т.В., Шабунова А.А. \\ Особенности исследования социального здоровья у детей младшего школьного возраста с ограниченными возможностями здоровья}

ФГБОУ ВО «Череповеиякий государственный университет»

doi 10.18411/gq-15-10-2021-06

(Россия, Череповеи)

\section{Аннотация}

В статье обращается внимание на важность формирования социального здоровья детей. Авторы обозначают, что проблемой является подбор инструментария, позволяющего на ранних этапах выявить факторы, снижающие социальное здоровье и благополучие младших школьников с ограниченными возможностями здоровья. В статье представлены основные результаты проведенного исследования социального здоровья младших школьников с ограниченными возможностями здоровья и детей с нормотипичным развитием.

Ключевые слова: социальное здоровье, дети с ограниченными возможностями здоровья, инструментарий.

\section{Abstract}

The article draws attention to the importance of developing the social health of children. The authors point out that the challenge is to find tools that allow early identification 
of factors that reduce the social health and well-being of young schoolchildren with disabilities. The article presents the main results of the social health research carried out on children with special needs and children with normal development.

Keywords: social health, children with special needs, tool.

Гармоничное существование детей в социальной среде возможно лишь при условии взаимопроникновения ребенка и социума. Для этого необходима интеграция личности в общество, а также удовлетворенность общества поведением и ценностями ребенка [3]. Условия среды воспитания во многом обусловливают социальное развитие детей и возможности укрепления их физического и социального здоровья. Л.С. Выготский [1] подчеркивает, что наличие дефекта в развитии у детей с ограниченными возможностями здоровья (OB3) не влияет на их социальное развитие, а воздействует на различные компоненты психического и социального развития через возникновение «социального вывиха». Н.В. Голицина считает, что у детей с ОВЗ возникают проблемы с психосоциальной адаптацией, а также с формированием основных механизмов социализации, следовательно, и с социальным здоровьем в целом [2]. Поэтому коррекционная педагогика и специальная психология должны быть направлены на профилактику нарушений социального здоровья детей с OB3, на обеспечение адаптации и социализации их к обществу. Это особенно важно в период адаптации к школьному обучению.

Для своевременного и грамотного вмешательства как коррекционным педагогам, так и учителям младших классов важно иметь достоверную информацию о возможных рисках, влияющих на формирование социального здоровья.

\section{Литературный обзор}

Проблеме выявления особенностей и рисков формирования социального здоровья детей младшего школьного возраста с ОВ3 посвящены многие исследования. Так Р.О. Дружинин, подчеркивая важность формирования социального здоровья, использует междисциплинарный подход и выделяет группы технологий социальной работы, способствующие сохранению социального здоровья детей. Среди них особую важность имеют диагностические (включая экспертизу, мониторинг социального положения детей), управленческие (воздействие на среду и личность), профилактические (в том числе, здоровьесберегающие технологии) [5].

Европейские исследователи особое внимание в формировании социального здоровья детей с ОВ3 придают инклюзивному образованию. При этом отмечают, что очень важно, чтобы учителя повышали свою квалификацию в отношении научно обоснованной практики инклюзивного образования, которая привела бы к успешному опыту учителей. А также необходима смена ценностных ориентиров в обществе на толерантное отношение к детям с особыми образовательными потребностями (важно для всех социальных групп: администрации, педагогов, родителей и детей) $[8,12,13$, $14]$.

Некоторые авторы для оценки социального здоровья использовали концепции оценки социальной интеграции. Камбра и Сильвестр (2003) полагались на "социализацию в группе сверстников" для измерения социальной интеграции детей (оценка социальных предпочтений и социального отвержения). Тейлор и Хоутон [15] использовали анализ дружеских отношений, чтобы оценить их уровень социальной интеграции. По мнению этих авторов, ребенок считается полностью социально интегрированным только в том случае, если у него есть три или более постоянных пар дружбы со сверстниками. Другие авторы (Флем, Келлер, Дюкетт) при обсуждении социальной интеграции и социального здоровья опираются на следующие индикаторы: 
дружеские отношения; самовосприятие учащихся, чувство принадлежности к школе, восприятие себя в школе, чувство одиночества; принятие сверстниками, восприятие сверстников, например, социальная поддержка, издевательства; и социальные взаимодействия со сверстниками и учителями, например, свободное время, совместные задания, участие в групповых / школьных мероприятиях и социальная изоляция $[9,10$, 11].

Многие исследователи (О.А. Денисова, О.Л. Леханова и др.) обращают внимание на важную роль семьи в социализации и формировании социального здоровья детей с ОВ3. В работах показано, что в семьях, воспитывающих детей с ОВ3 более низкий уровень общения, часто родители стесняются своих детей и не желают, чтобы в обществе знали о проблемах ребенка, либо чрезмерно опекают ребенка, сужая круг его общения и ограждая от посильной работы. Авторы подчеркивают, что неумение примириться с ситуацией и принять ребенка, неготовность к преодолению трудностей приводят к десоциализации не только детей с ОВ3, но и их родителей [4].

\section{Материалы и методы}

Цель исследования - выявление особенностей социального здоровья детей младшего школьного возраста с ограниченными возможностями здоровья в сравнении с нормотипично развивающимися детьми того же возраста.

Для достижения цели была разработана анкета, состоящая из двух блоков. Первый блок направлен на выявление социального неблагополучия путем сплошного анкетирования школьников и выявления групп риска. Второй блок - предполагает изучение уровня школьной мотивации.

Опрос проводился на базе БУ ВО «Областной центр ППМСП». Опрошено было 30 детей с ОВ3 и 31 нормотипично развивающийся ребенок. Результаты опроса обработаны с помощью статистического пакета SPSS Statistic.

\section{Результаты исследования}

Для выявления социального неблагополучия детей младшего школьного возраста в I блоке анкеты изучалось: материальное благополучие, состояние здоровья и защищенность, образование, отношение в семье и со сверстниками, поведенческие и средовые риски и самооценка детьми уровня своего благополучия.

Материальное благополучие.

Важным факторами формирования материального благополучия любой семьи выступают: трудовая занятость родителей, характеристика семьи (полная, неполная), число детей в семье, также влияет и совместное проживание с прародителями.

У всех детей, участвующих в исследовании, родители работали. Исследование выявило более высокие риски материального неблагополучия в семьях с детьми с ОВЗ. Так, например, среди детей с ОВ3 27,8\% воспитываются в неполных семьях (20,7\% нормотипичные дети). Кроме того, дети с ОВ3 чаще воспитываются в многодетных семьях (16,7\% у детей с ОВ3 в сравнении с $13,8 \%$ у контрольной группы). Несмотря на то, что большинство семей проживают отдельно от бабушек и дедушек $(74,5 \%)$, отметим, что семьи, воспитывающие детей с ОВ3, несколько реже проживают с прародителями.

Еще одним индикатором материального благополучия семьи, отражающемся как на развитии детей, так и на их школьных успехах, является наличие обустроенного места для занятий дома. Результаты опроса показали, что специальное место или стол для занятий есть у 77,8\% детей с ОВ3 (100\% нормотипичные дети); компьютер (ноутбук) для выполнения школьных заданий есть у 66,7\% детей с ограниченными возможностями здоровья (79,3\% нормотипичные дети); доступ в Интернет есть 83,3\% детей с ОВ3 (96,6\% нормотипичные дети, рис. 1). 


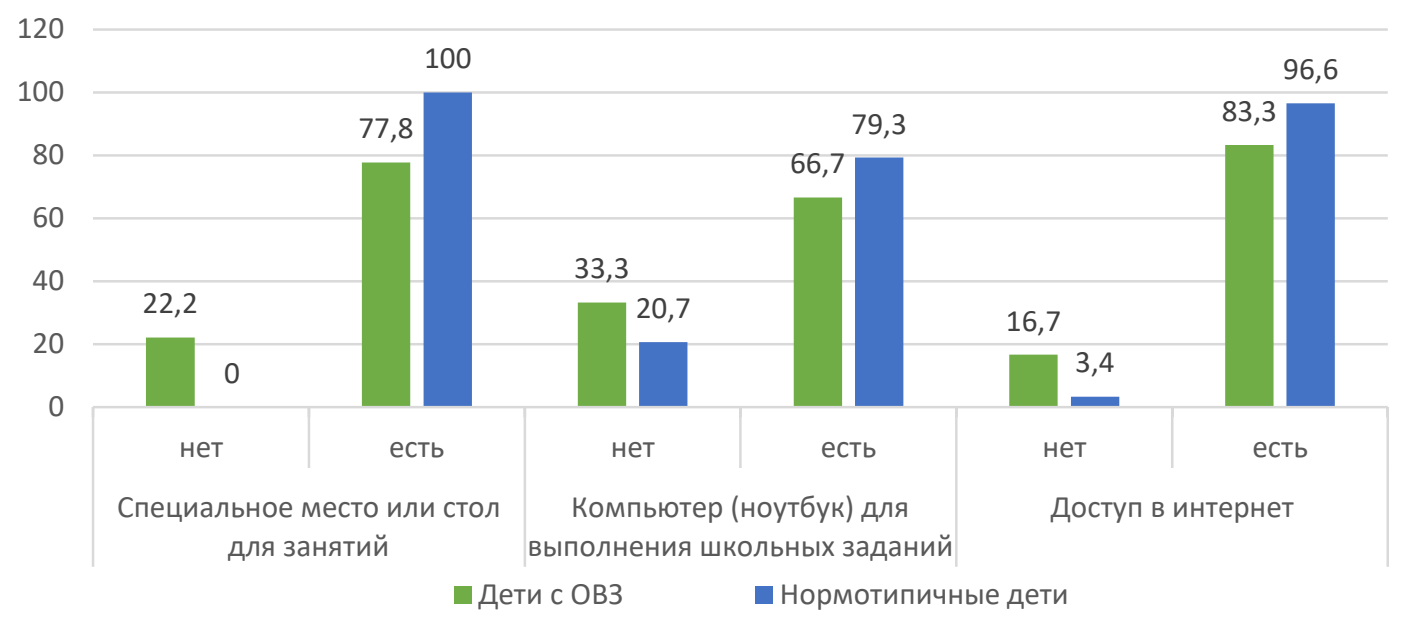

Рисунок 1. Обустройство места для занятий дома (в \% от числа опрошенньх)

\section{Состояние здоровья и защищщенность.}

Физическое здоровье является важным компонентом социального здоровья. В исследовании использовался метод самооценки. Дети оценивали свое здоровье по шкале от отличного до плохого. Анализ показал, что дети с OB3 чаще оценивают свое здоровье как хорошее $(61,1 \%)$, в то время как дети из контрольной группы оценивают свое здоровье как отличное $(51,7 \%)$. Также выявлено, что 5,6\% детей с ОВ3 оценили свое здоровье как плохое, в контрольной группе таких оценок нет.

Осознание важности заботы о здоровье и организация свободного времени для формирования здоровьесберегающих практик являются значимым компонентом в формировании социального здоровья. В семьях, воспитывающих детей с OB3, анализ выявил более низкий уровень здоровьесберегающих практик. Исследование показало, что дети с ОВ3 реже занимаются физкультурой и спортом $(61,1 \%)$, чем нормотипичные дети $(72,4 \%)$, а также реже соблюдают режим дня - 38,9\% (51,7\% нормотипичные дети, рис. 2). Оценивая свое питание нормотипичные дети в 1,7 раза чаще называют его правильным (27,8\% дети с ОВ3; 48,3\% нормотипичные дети). Важными моментами заботы о здоровье являются элементы самоконтроля, к которым можно отнести соблюдение режима работы на компьютере и умение справляться с плохим настроением. И если относительно настроения половина и более детей отметили, что умеют его контролировать, то при работе с компьютером только треть детей соблюдают режим, остальные находятся в группе риска по формированию социального здоровья.

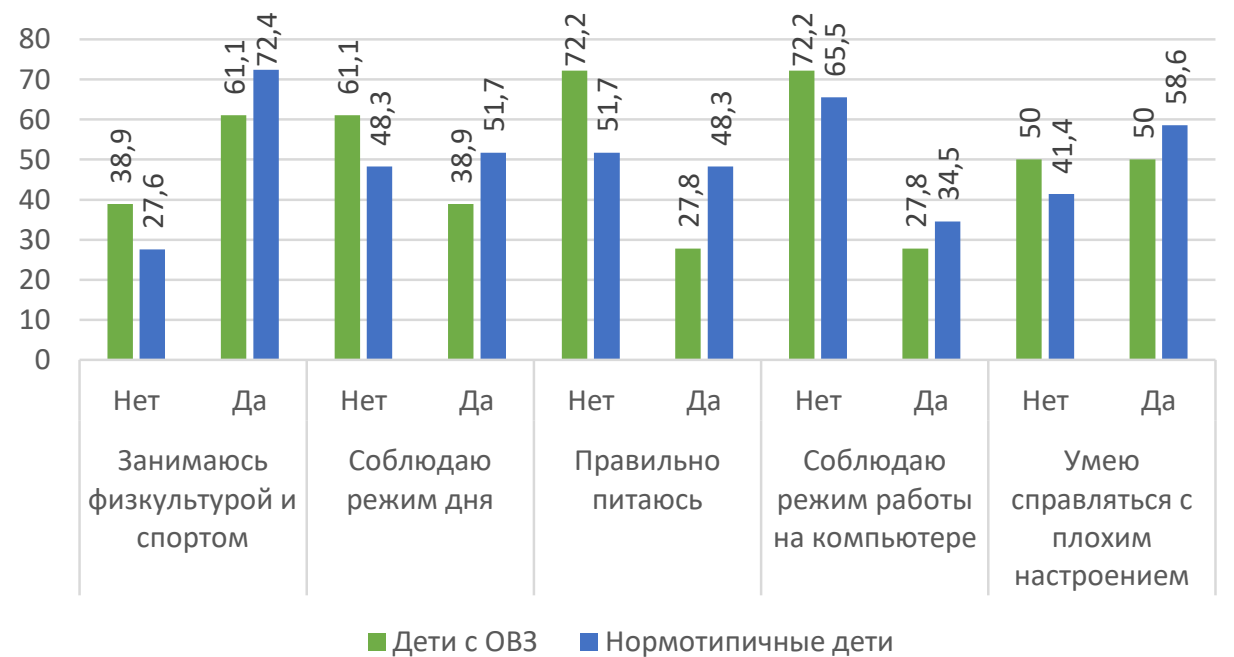

Рисунок 2. Что ты делаешь для того, чтобы быть здоровым (в \% от числа опрошенных) 


\section{Образование.}

Несмотря на заметное превалирование у детей с ОВ3 факторов риска социального здоровья, благодаря реализации адаптированных основных общеобразовательных программ в образовательных организациях успеваемость детей с OB3 сопоставима с успеваемостью детей, обучающихся по основным программам. В большинстве случаев дети оценивают свою успеваемость на «4» и «5».

Отночение в семье и со сверстниками.

Важным элементом социального здоровья является правильные взаимоотношения ребенка и родителя. Исследование показало, что дети с ОВ3 реже рассказывают родителям о своих успехах и трудностях реже $(61,1 \%)$, чем нормотипичные дети $(86,2 \%)$. Около $10 \%$ детей с ОВ3 не делятся с родителями своими переживаниями и радостями.

У абсолютного большинства детей есть друзья и нравится общение с одноклассниками. Также около $22 \%$ детей с ОВ3 отметили, что у них один друг и не очень нравятся взаимоотношения с одноклассниками, что создает предпосылки к социальной изоляции этих школьников.

\section{Поведенческие и средовые риски.}

К поведенческим и средовым рискам в своем исследовании мы отнесли отношение детей к курению, употреблению алкоголя и наркотиков. Анализ данных показал, что абсолютное большинство испытуемых (80,9\%) отрицательно относятся к употреблению наркотиков. Также большинство детей отрицательно относится к курению $(63,8 \%)$ и употреблению алкоголя $(76,6 \%)$. Однако стоит отметить, что 5,6\% детей с ОВ3 выявили положительное отношение к алкоголю $(0,0 \%$ нормотипичные дети) и $16,7 \%$ - к курению (10,3\% нормотипичные дети). И это может быть основой для формирования здоровьеразрушающих привычек в более старшем возрасте.

Самооценка детьми уровня своего благополучия.

Для самооценки детьми уровня своего благополучия была адаптирована методика «Лесенка» (В.Г. Щур) [7]. Детям предлагалось отметить ступеньку (цифру), которая лучше всего отражает их положение на этой лесенке. Где самая верхняя ступенька лестницы - это 10 баллов, т.е. живется очень хорошо, а нижняя ступенька это 0 , т.е. живется очень плохо.

При анализе данных разделили полученные ответы на три уровня по степени самооценки опираясь на основную методику. Завышенная самооценка (10, 9, 8 ступеньки) чаще всего характерна для детей младшего школьного возраста и является возрастной нормой. Это связано со слабо развитой рефлексией (способностью анализировать свою деятельность и соотносить мнения, переживания и действия с мнениями и оценками окружающих). Адекватная самооценка (7, 6, 5 ступеньки) - у ребенка сформировано положительное отношение к себе, он умеет оценивать себя и свою деятельность. Это нормальный вариант развития самооценки. Низкая и очень низкая самооценка $(4,3,2,1,0$ ступеньки) может формироваться по разным причинам. Иногда у ребенка самооценка занижается ситуативно (на момент опроса могло, что-то произойти, например, ссора с товарищем, неудача на уроке), в этом случае через несколько дней самооценка может выправиться и стать более высокой. Более серьезным является наличие стойких мотивированных ответов ребят с ощущением «я плохой». Опасность этой ситуации в том, что низкая самооценка может остаться на всю жизнь и не позволит раскрыться способностям и возможностям ребенка. Выбранные очень низкие позиции на «лесенке» ситуацию школьной дезадаптации, личностного и эмоционального неблагополучия.

Исследование показало, что у большинства детей завышенная и адекватная самооценка, что является нормой, также были выявлены единичные случаи низкой и очень низкой самооценки у детей (табл. 1). 
Таблица 1

Самооченка детьми уровня своего благополучия

\begin{tabular}{|c|c|c|c|}
\hline & Дети с ОВЗ, в \% & $\begin{array}{c}\text { Нормотипичные } \\
\text { дети, }, \%\end{array}$ & Всего, в \% \\
\hline Завыменная & 50,0 & 69,0 & 61,7 \\
\hline Адекватная & 44,4 & 27,6 & 34,0 \\
\hline Низкая и очень низкая & 5,6 & 3,4 & 4,3 \\
\hline Всего & 100,0 & 100,0 & 100,0 \\
\hline
\end{tabular}

Семьям, где выявлены 3 и более факторов риска социального неблагополучия (22,3\% детей с OB3; 6,8\% нормотипичных детей), необходима помощь со стороны социальных педагогов, учителей для смягчения или ликвидации факторов риска (табл. 2). Таким образом, проведенное исследование показало состоятельность методики по изучению и выявлению группы риска детей по социальному неблагополучию.

Таблийа 2

Число факторов риска

\begin{tabular}{|c|c|c|c|}
\hline Число факторов риска & Дети с ОВЗ, в\% & $\begin{array}{c}\text { Нормотипичные } \\
\text { дети, в } \%\end{array}$ & Всего, в \% \\
\hline 0 & 5,6 & 6,9 & 6,4 \\
\hline 1 & 44,4 & 51,7 & 48,9 \\
\hline 2 & 27,8 & 34,5 & 31,9 \\
\hline 3 & 5,6 & 3,4 & 4,3 \\
\hline 4 & 11,1 & 3,4 & 6,4 \\
\hline 5 & 5,6 & 0,0 & 2,1 \\
\hline Всего & 100,0 & 100,0 & 100,0 \\
\hline
\end{tabular}

Во II блоке оценивался уровень школьной мотивации по Н. Лускановой [6].

Исследование показало, что положительная школьная мотивация (хорошая школьная мотивация и положительное отношение к школе) у детей с ОВ3 составляет $44,5 \%$, что ниже в сравнении с нормотипично развивающимися детьми, у которых положительная мотивация составляет 65,5\%. Больше, чем у половины детей с OB3 $(55,6 \%)$ низкая школьная мотивация (низкая школьная мотивация и негативное отношение к школе), у контрольной группы этот показатель составляет $34,4 \%$ (табл. 3 ). Это свидетельствует о том, что дети с ОВЗ требуют большего внимания со стороны педагогов и семьи для снижения рисков социальной дезадаптации.

Таблица 3

Уровень школьной мотивачии

\begin{tabular}{|c|c|c|c|}
\hline & Дети с ОВЗ, в \% & $\begin{array}{c}\text { Нормотипичные } \\
\text { дети, в \% }\end{array}$ & Всего, в \% \\
\hline Хорошая школьная мотивация & 5,6 & 10,3 & 8,5 \\
\hline Положительное отношение к школе & 38,9 & 55,2 & 48,9 \\
\hline Низкая школьная мотивация & 50,0 & 31,0 & 38,3 \\
\hline Негативное отночение к школе & 5,6 & 3,4 & 4,3 \\
\hline Всего & 100,0 & 100,0 & 100,0 \\
\hline
\end{tabular}

Таким образом, в представленном материале показаны основные особенности компонентов социального здоровья детей с ОВЗ. Полученные данные могут быть использованы для определения направления психолого-педагогического воздействия коррекционными педагогами и учителями начальных классов при формировании социального здоровья детей младшего школьного возраста с ОВ3.

$* * *$

1. Выготский Л.С. Основы дефектологии / Л.С. Выготский. - СПб.: Лань, 2003. - 654 с.

2. Голицина Н.В. Профилактика нарушений социального здоровья как условие социализации детей с ОВ3 / Н.В. Голицина // Череповецкие научные чтения. - Череповец, 2014. - C. 42 - 45. 
3. Денисова О.А. Социальное развитие детей с ограниченными возможностями здоровья: угрозы и перспективы решения в региональном контексте / О.А. Денисова, О.Л. Леханова // Научный электронный архив. URL: http://econf.rae.ru/article/6388 (дата обращения: 14.09.2021)

4. Денисова О.А. Угрозы социального развития детей с ограниченными возможностями здоровья в семейной среде / О.А. Денисова, О.Л. Леханова, Р.А. Самофал, Н.В. Голицина // Вестник Череповецкого государственного университета. - 2013. - № 3 - 1 (49). - С. 105 - 108.

5. Дружинин Р.О. Социальное здоровье детей: сущность и технологии сохранения / Р.О. Дружинин // Социально-экономические явления и процессы - 2011. - № 9 (31). - С. 255 - 259.

6. Методика изучения уровня школьной мотивации H. Лускановой. URL: https://www.sites.google.com/site/psistd/diagnostika/2-1.

7. Щур, В.Г. Методика изучения представлений ребенка об отношениях к нему других людей / В.Г. Щур // Психология личности: теория и эксперимент: сб. науч. тр. - Москва: Изд-во АПН, 1982.

8. Ainscow, M. Developing Inclusive Education Systems: The Role of Organisational Cultures and Leadership. / M. Ainscow, A. Sandill // International Journal of Inclusive Education. - 2010. - № 14 (4). - P. 401 - 416. doi:10.1080/13603110802504903.

9. Duquette, C. Persistence in high school: Experiences of adolescents and young adults with fetal alcohol spectrum disorder / C. Duquette, E. Stodel, S. Fullarton, K. Hagglund // Journal of Intellectual \& Developmental Disability. - 2006. - № 31 (4). - P. 219 - 231.

10. Duquette, C. Secondary school experiences of individuals with foetal alcohol spectrum disorder: Perspectives of parents and their children / C. Duquette, E. Stodel, S. Fullarton, K. Hagglund // International Journal of Inclusive Education. - 2007. - № 11 (5-6). - P. 571 - 591.

11. Flem, A. Inclusion in Norway: A study of ideology in practice / A. Flem, C. Keller // European Journal of Special Needs Education. - 2000. - № 15 (2). - P. 188 - 205.

12. Grima-Farrell, C. R. Bridging the Research-to-practice gap: A Review of the Literature Focusing on Inclusive Education / C. R. Grima-Farrell, A. Bain, S. H. McDonagh // Australasian Journal of Special Education. - 2011. - № 35 (02). - P. 117 - 136. doi:10.1375/ajse.35.2.117.

13. Lindsay, G. Educational Psychology and the Effectiveness of Inclusive Education/Mainstreaming / G. Lindsay // British Journal of Educational Psychology. - 2007. - № 77 (1). - P. 1 - 24. doi:10.1348/000709906X156881.

14. Pijl, S. J. Students with Special Needs and the Composition of Their Peer Group / S. J. Pijl, E. M. Skaalvik, S. Skaalvik // Irish Educational Studies. - 2010. - № 29 (1). - P. 57 - 70. doi:10.1080/03323310903522693.

15. Taylor, M. Difficulties in initiating and sustaining peer friendships: Perspectives on students diagnosed with ADHD / M. Taylor, S. Houghton // British Journal of Special Education. - 2008. - № 35 (4). - P. $209-19$.

\section{Нестеренко В.Г., Матвиенко Л.М. Секрет успеха подготовки учителя в Финляндии}

Волгоградский государственный сочиально-педагогический университет (Россия, Волгоград)

doi 10.18411/gq-15-10-2021-07

\section{Аннотация}

Представлен анализ процесса организации педагогического образования в Финляндии. Уточнены особенности построения обучения с целью обеспечения высочайшего качества программ подготовки учителей; строжайшего отбора в педагогические вузы; организации педагогической практики студентов; многоуровневого оценивания качества готовности выпускников к работе в школе; политики государства в области постдипломного образования учителей. Предложено учесть финский опыт педагогического образования в России.

Ключевые слова: высококвалифицированный педагог, процесс отбора учителей, стратегии обучения и учебные планы, педагогическая практика, обучение в течение жизни.

\section{Abstract}

Presented analysis of the teacher's training process in Finland. Clarified the features of building education courses with the aim of ensuring the highest quality teacher's training programs, rigorous selection for entry to teacher education courses, practical experience 
structuring; multilevel assessment of graduates to ensure classroom readiness; state policy in the field of postgraduate teachers' education. Suggested to take into account the Finnish experience of pedagogical education in Russia.

Keywords: highly qualified teacher, teacher selection process, learning strategies and curricula, teaching practice, lifelong learning.

У молодых финнов профессия учителя неизменно является наиболее популярной профессией, что подтверждается регулярными опросами выпускников средних школ [1]. Чтобы стать учителем начальной школы в Финляндии, нужно выдержать серьезный конкурсный отбор. Только лучшие и самые талантливые финны способны отобраться в педагогические вузы. Каждую весну тысячи выпускников школ подают заявки на отделения педагогического образования в восьми финских университетах. Обычно недостаточно окончить среднюю школу и иметь хороший аттестат зрелости, кандидаты должны иметь самые высокие баллы и отличные коммуникативные навыки. Например, только один из десяти заявителей принимается для обучения. Ежегодно в стране приблизительно из 20000 абитуриентов студентами становятся только 5000.

Процесс отбора учителей начальной школы состоит из двух этапов: во-первых, отбирается группа кандидатов на основании результатов экзаменов на аттестат зрелости, аттестата о среднем образовании, выданного школой, и соответствующих достижениях вне школы. На втором этапе:

1. кандидаты завершают письменный экзамен на знание материалов определенной литературы по педагогике;

2. кандидаты участвуют в деятельности, воспроизводящей школьные ситуации, где должны продемонстрировать социальные и коммуникативные навыки;

3. лучшие кандидаты проходят собеседование, в процессе которого объясняют почему они решили выбрать педагогическую специальность.

Самые талантливые кандидаты обучаются по строго выстроенной программе подготовки учителей за счет государства [1].

До середины 1970-х годов учителя начальной школы обучались в педагогических колледжах. Учителя средних и старших классов учились на предметных факультетах финских университетов. К концу 1970-х годов все программы педагогического образования стали университетскими. В то же время научный контент и методология образовательных исследований начали обогащать учебную программу педагогического образования. Педагогическое образование теперь основано на результатах научных исследований, должно поддерживаться научными знаниями и фокусироваться на процессах мышления и когнитивных навыках, используемых в проведении научных исследований [2]. Требование для работы в качестве учителя во всех базовых и средних школах Финляндии сегодня является магистерская степень. Воспитатели и педагоги дошкольных учреждений должны иметь степень бакалавра.

Конечно, основным и самым важным видом деятельности финских учителей является непосредственно преподавание в школе, однако, немалую часть своего рабочего времени они уделяют внеклассной работе с детьми и коллегами. Формально рабочее время учителя в Финляндии состоит из обучения в классе, подготовки к уроку и двух часов в неделю для планирования работы совместно с коллективом школы. С международной точки зрения, финские учителя уделяют меньше времени преподаванию, чем учителя во многих других странах. Например, типичный учитель средней школы в Финляндии преподает менее 600 часов в год, что соответствует примерно четырем 45-минутным занятиям в день. А по данным ОЭСР 2008 года, в Соединенных Штатах, напротив, учитель того же уровня должен проводить 1080 часов 
в классе более 180 школьных дней, [3]. Это означает, что учитель средней школы в Соединенных Штатах в среднем уделяет в два раза больше времени преподаванию в классе по сравнению с его коллегой в Финляндии.

Это, однако, не означает, что учителя в Финляндии работают меньше, чем в других странах. Важная - и все же добровольная - часть работы финских преподавателей посвящена совершенствованию предметного содержания преподавания и педагогической деятельности школы в целом, включая участие в методических и научных мероприятиях и работе с родителями и другими сообществами. Поскольку финские преподаватели берут на себя основную ответственность за учебную программу и оценку, а также экспериментируют и совершенствуют методы преподавания, некоторые из наиболее важных аспектов их работы проводятся вне классных аудиторий.

Заработная плата не является основной причиной того, что молодые люди становятся учителями в Финляндии. Учителя получают среднюю заработную плату по стране, что соответствует приблизительно 38500 долларов США [3]. Более важными, чем заработная плата, являются такие факторы, как высокий социальный престиж, профессиональная автономия в школах и дух преподавания как услуги обществу и общественному благу. Таким образом, молодые финны рассматривают обучение как карьеру наравне с другими профессиями, где люди работают независимо и полагаются на научные знания и навыки, которые они получили благодаря университетским знаниям и научным исследованиям.

Все преподаватели имеют ученые степени. Учителя начальной школы имеют более всестороннее образование, в то время как преподаватели средней школы концентрируют свои исследования на определенном предмете, например, математике, а также дидактике, состоящей из педагогических знаний, характерных для этого предмета. В Финляндии нет альтернативных способов получить диплом учителя: университетская степень представляет собой лицензию на преподавание.

Судя по работам финских исследователей в области образования, подготовка будущих учителей направлена на сбалансированное развитие личных и профессиональных качеств учителя. Особое внимание уделено построению навыков педагогического мышления, которые позволяют учителям управлять учебным процессом в соответствии с современными знаниями и практикой [4].

Студенты - будущие учителя начальных классов изучают три основные области: (1) теория образования, (2) дисциплинарное содержание и (3) предметная дидактика или методика и практика. Каждый студент готовит и защищает магистерскую диссертацию.

В настоящее время финские университеты предлагают двухуровневую программу обучения. За обязательной трехлетней программой обучения на степень бакалавра следует двухгодичная магистерская программа. Для бакалавриата и магистратуры предусмотрены мультидисциплинарные программы, по крайней мере по двум предметам. Освоение дисциплин оценивается в кредитных единицах по Европейской системе перевода и накопления кредитов (ECTS), используемой в 46 европейских странах. ECTS основывается на предположении, что 60 кредитов измеряют рабочую нагрузку очного студента в течение одного учебного года, а каждый кредит ECTS составляет около 25-30 академических часов. Требования к педагогическому образованию - 180 кредитов ECTS для степени бакалавра и 120 кредитов ECTS для получения степени магистра. Из документов Министерства образования Финляндии, следует, что успешное завершение магистратуры в области образования (включая степень бакалавра) обычно занимает от пяти до семи с половиной лет [5].

Насыщенный учебный план обеспечивает студентов сбалансированными теоретическими знаниями и практическими навыками. Это также означает, что 
будущие преподаватели обладают глубоким профессиональным психологопедагогическим пониманием задач образования и обучения и имеют представление о сопутствующих педагогических вопросах - психологии, социологии, инклюзивного обучения, и т.д. Во всех восьми университетах Финляндии есть свои собственные стратегии обучения и учебные планы в области педагогического образования, которые координируются на национальном уровне для обеспечения согласованности, но создаются автономно, с тем чтобы наилучшим образом использовать ресурсы университета и других локальных институтах, связанных с образованием.

Как правило, подготовка учителей начальных школ включает 60 кредитов ECTS для предметно-педагогической подготовки, и как минимум 60 кредитов ECTS для других курсов в области педагогических наук. Магистерская диссертация требует самостоятельных исследований, участия в научных семинарах и подготовки презентации итогового научно-учебного исследования. Общий кредитный вес, связанный с этой исследовательской работой во всех университетах, составляет 40 кредитов ECTS. Знания, связанные с преподаванием школьных предметов, подкрепляются модулями педагогической практики, включенными в программу. Одна из целей - подчеркнуть взаимосвязь теории и практики путем установления связи между теоретическими занятиями в кампусе и практикой преподавания в школепартнере. Всего на педагогическую практику во время этих занятий выделяется 20 кредитных единиц. Модуль мультидисциплинарной педагогической практики уделяет особое внимание педагогическим знаниям, относящимся к различным видам воспитательно-педагогической деятельности непосредственно в классе. Студентыпрактиканты имеют возможность апробировать и улучшать свои навыки преподавания различных предметов на основе теоретических исследований, а также, поучаствовать в воспитательных мероприятиях в соответствии с образовательными целями начальной школы.

Обучение учителей - предметников осуществляется по тем же принципам, что и обучение учителей начальных классов, но организуется по-другому. Студенты различных факультетов, например, математики, музыки, истории, и др. проводят исследовательскую работу по своему первому предмету (90 кредитов ECTS) и второму предмету (60 кредитов ECTS). Как правило, Департамент педагогического образования Финляндии сотрудничает с факультетами, которым рекомендовано консультироваться по вопросам создания и наполнения учебных планов и модулей по тем или иным предметам. Практика составляет одну треть зачетных единиц педагогических подготовки. Во время практического обучения студентам оказывается всесторонняя поддержка. Кураторы педпрактики контролируют деятельность студентов, организуют обсуждения, где происходит детальный пошаговый разбор проведенных самостоятельно мероприятий. Это способствует глубокому анализу, рефлексии практикантов для улучшения их педагогической практики и дальнейшей педагогической деятельности [6]. На этом этапе очень важен контроль, и подготовленные наставники помогают студентам-практикантам осмыслить все аспекты их работы в качестве учителей. Практика преподавания интегрирована как в теоретические, так и в методологические исследования. В течение пятилетней программы студенты переходят от базовой практики к «продвинутой» (с применением передовых методик), а затем к итоговой практике (на определение профессиональной пригодности). Во время каждого из этих этапов студенты наблюдают за уроками опытных преподавателей, практикуют преподавание под наблюдением учителей наставников, и демонстрируют самостоятельные уроки для разных групп учащихся. Их оценивают учителя школ и преподаватели-кураторы педагогического факультета.

В рамках педагогических образовательных программ в Финляндии есть два основных вида практического опыта. Первая - небольшая часть клинического обучения - проводится на семинарах и занятиях в малых группах в Департаменте образования, 
где студенты практикуют базовые навыки преподавания перед своими однокурсниками. Вторая - основная практика преподавания - происходит в основном в специальных экспериментальных школах, которые управляются университетами и имеют аналогичные учебные планы, как и в обычных государственных школах. Будущие учителя начальных школ проводят около 15 процентов времени обучения (около 40 кредитов ECTS) на практике в школах. Для студентов - предметников это время составляет примерно одну треть учебного плана.

Правительство в лице Министерства образования всячески поощряют дальнейшее профессиональное совершенствование педагогов. Финские учителя со степенью магистра имеют право обучаться в докторантуре. Многие преподаватели пользуются возможностью освоить курс докторантуры в области образования, часто одновременно с преподаванием в школе.

Несмотря на то, что финское педагогическое образование было высоко оценено за его систематическую академическую структуру и высокое качество, правительство планирует существенное увеличение бюджетов профессионального развития и рассматривает пути обеспечения того, чтобы все учителя имели доступ к адекватной профессиональной подготовке, постдипломному образованию и курсам повышения квалификации, финансируемыми муниципалитетами. Государственный бюджет ежегодно выделяет около 30 миллионов долларов на профессиональное развитие учителей и директоров школ посредством различных форм повышения квалификации и непрерывного образования. Правительство определяет направленность обучения, основанное на текущих национальных потребностях в области развития образования, и обучение на контрактной основе предоставляется поставщикам услуг на конкурсной основе. Министерство образования совместно с Министерством финансов Финляндии в сотрудничестве с муниципалитетами планировало удвоить государственное финансирование профессионального развития учителей к 2020 году [7].

$$
* * *
$$

1. Helsingin Sanomat, 2004 Helsingin Sanomat (2004). Ykkössuosikki: Opettajan ammatti [Top favorite: Teaching profession]. February 11, 2004.

2. Jakku-Sihvonen \& Niemi, 2006 Jakku-Sihvonen, R. \& Niemi, H. (Eds.) (2006). Researchbased teacher education in Finland: Reflections by Finnish teacher educators. Research Report 25. Turku: Finnish Educational Research Association.

3. OECD (2008). Education at a glance. Education indicators. Paris: OECD

4. Westbury et al., 2005 Westbury, I., Hansen, S-E., Kansanen, P. \& Björkvist, O. (2005). Teacher education for research-based practice in expanded roles: Finland's experience. Scandinavian Journal of Educational Research, 49(5), 475-485.

5. Ministry of Education and Culture. [Электронный pecypc]. - Режим доступа: https://minedu.fi/koulutusselonteko/henkilosto

6. Rodgers C. Defining reflection: Another look at John Dewey and reflective thinking. Teachers College Record. 2002;104(4):842-856

7. Ministry of Finance. Europe 2020 Strategy - Finland's National Reform Programme; Spring 2017. Ministry of Finance publications - 18c/2017

\section{Шаповалов М.В. \\ Информационно-коммуникационные технологии в системе воспитательной работы учреждений общего образования}

РГБУ ДПО «Карачаево-Черкесский республиканский институт повышения квалификачии работников образования»

(Россия, Черкесск)

doi 10.18411/gq-15-10-2021-08

\section{Аннотация}

Интенсивное развитие процессов информатизации образования определяет возможности совершенствования воспитательной работы учреждений общего образования средствами ИКТ. В статье рассматриваются вопросы организации 
педагогической деятельности учителей в информационном формате урока. Предлагаются решения проблемы интеграции интеллектуального и физического труда, проблемы усиления воспитывающего потенциала аксиологического подхода к осуществлению образовательного процесса школы.

Ключевые слова: Информационно-коммуникационные технологии, воспитательная работа, развитие личности, интеграция интеллектуального и физического труда, урок, образование, учреждение общего образования.

\section{Abstract}

The intensive development of the processes of informatization of education determines the possibilities of improving the educational work of general education institutions by means of ICT. The article deals with the organization of pedagogical activity of teachers in the information flow of the lesson. The solutions to the problem of integration of intellectual and physical labor, the problem of strengthening the educational potential of the axiological approach to the implementation of the educational process of the school are proposed.

Keywords: Information and communication technologies, educational work, personal development, integration of intellectual and physical labor, lesson, education, general education institution.

Инновационные концепции преподавания школьных предметов, включенных в действующие Федеральные образовательные стандарты общего образования (начального общего образования - НОО, основного общего образования - ООО), ориентированы на создание условий для совершенствования методики их изучения. В эпоху цифровизации непрерывного образования совершенствование методик изучения школьных дисциплин предполагает обязательность разработки системы заданий по эффективному использованию информационно-коммуникационных технологий, оптимизирующих процессы достижения школьниками планируемых результатов учебной деятельности.

Анализ личностных достижений обучающихся, осуществляемый в контексте оценки качества и мониторинга результатов освоения программы ,позволяет согласиться с выводами о необходимости усилить внимание к изучению предметов, интегрирующих возможности гармоничного развития умственной и трудовой деятельности [7]. Таким предметом в условиях обучения школьников 1-4 классов, 5-9 классов является технология, теоретическое и практическое содержание которого связано с уникальным феноменом труд,а его функциональная природа формировалась и развивалась в условиях исторического процесса человека разумного. Классический путь динамических изменений этого явления - труд отражал сначала приоритет физического, затем - интеграцию физического и умственного (смешанный труд), впоследствии - приоритет умственного.

Уникальность нашего времени, по мнению ученых Э.Ф. Зеер, А.И. Кочетова, С.Н.Чистяковой, А.Д. Шатовой, М.П. Щетинина и др., во многом определяется реалиями происходящего антропологического кризиса, рисками недооценивания позитивного влияния труда, трудовой деятельности, трудового воспитания, физической нагрузки на развитие ребенка, взрослеющего человека.

В логике антропологического кризиса очевидна опасность негативной тенденции утраты традиционного отношения к труду как мощному, единственному потенциалу финансово-экономической устойчивости человека, его социального, финансового, духовно-нравственного благополучия. При этом, пишут М.К. Мамардашвили, А.Г. Асмолов, В.И. Слободчиков, В.И.Букреев и др., усиливаются деструктивные явления «расчеловечивания человека». Вопрос: что делать? объединяет ученых и практиков, признающих необходимость разработки методик психолого-педагогической поддержки укрепления мотивационного отношения детей к 
признанию труда не только как ценностно необходимой черты характера личности, но и как социально-ценностного качества человека, противостоящего опасности лени разрушительного порока человека. Базовые основания такой направленности в изучении школьных предметов прозрачно сформулированы в Законе об образовании в РФ, признающем приоритетность воспитания при трактовке феномена образование: «образование - единый целенаправленный процесс воспитания и обучения». (статья 2). Целью образования сегодня признано интеллектуальное, духовно-нравственное, творческое, физическое и (или) профессиональное развитие человека. Деятельностью, обеспечивающей такое многоплановое развитие личности (интеллектуальное, духовное, физическое, трудовое и т.д) становится воспитание. Следовательно, целостность образовательного пространства Российского государства (самого большого в мире по территории ) стратегически поддерживается ориентиром на процессуальность образования и деятельностную обеспеченность ресурсами интеллектуального, физического, духовно-нравственного воспитания. Итак, признание целевого предназначения трудового воспитания, наряду с воспитанием духовно-нравственным, очевидно. Это, с нашей точки зрения, укрепляет педагогические основания преподавания школьных дисциплин,процесс формирования средствами этих дисциплин условий для позитивной мотивации отношения обучающихся к труду, трудовой деятельности , но только не в ущерб овладения ими информационной грамотностью и информационной культурой. Анализ учебной деятельности школьников, как показывают данные нашего педагогического эксперимента (2016-2020), подтверждает выводы о том, что в детской среде значительно повышается интерес к использованию ИКТ, ориентированных на трудовую деятельность, связанную с конструированием и моделированием вещей, изготовление которых в материале производят сами обучающиеся.(7) В процессе интеграции трудовых процессов (интеллектуальных, физических) школьники испытывают радость творческих открытий, удовлетворение результатами своего труда (материализация замысла в своем авторском рукотворном изделии). В таких условиях вызревают реальные возможности для преодоления тенденциозного игнорирования физического труда, преодоления психологического барьера отрыва труда физического от интеллектуального.

В систему условий, важных для использования дидактических ресурсов ИКТ в работе по трудовому воспитанию, по совершенствованию методики преподавания школьных предметов, включается деятельность по формированию у обучающихся «практических умений и опыта, необходимого для организации собственной жизни» [2, c.2].

Знакомство с опытом использования ИКТ в работе по трудовому воспитанию в регионах РФ открывает особые достижения учреждений образования, например, Республики Татарстан(4;6).Адаптированный к условиям жизни других регионов,этот опыт значительно обогащает методики проведения уроков технологии в информационном формате. Так, разрабатываются задания на применение компьютерной графики при проектировании моделей с последующим их воплощением «в материале», что соответствует возможностям интеграции интеллектуального и физического труда, необходимым для освоения умений и навыков в сфере робототехники, конструирования в информационном потоке при оптимальном введении в урок процессов ручного труда. Практика показывает, что при этом открываются новые возможности профессиональной ориентации, поддерживающей престиж рабочих профессий, интерпретирующей изменения в системе среднего профессионального образования: подготовка специалистов по программе «Профессионалитет», на обучение по которой уже в 2022 году будет принято около 150000 человек для обучения в колледжах. 
Повышение плотности и эффективности информационного потока на уроках технологии предполагает освоение школьниками ключевых понятий, отражающих содержание этой дисциплины. При этом широко используются ресурсы интернета для актуализации средств национального корпуса русского языка, способов толкования лексического значения опорной лексики и фразеологии уроков технологии, для интерпретации синонимических рядов, включающих эти номинативные единицы. В экспериментальной работе в состав ключевых понятий уроков технологии включались такие языковые единицы, как: труд, безопасность жизнедеятельности, охрана здоровья, учебная деятельность, физический труд, умственный труд, конструирование, моделирование, профессиональная ориентация, информационная безопасность, виды трудовой деятельности, творческа деятельность, исследовательская деятельность, профессиональная подготовка, ручной труд, рынок труда, рукотворный мир, нерукотворный мир и т.д.

Деятельностно-системный, аксиологический подходы к организации применения интернета на уроках технологии создают условия для соединения физического и интелектуального труда, значительно снижают риски «непонимания детьми реальности» ( М.К. Мамардашвили), укрепляют образовательную среду школы продуктивной деятельностью по трудовому воспитанию обучающихся средствами информационно-коммуникационных технологий.

$$
* * *
$$

1. Аствацатуров Г.И. Технологии конструирования мультимедийного урока. - М., 2002. -26 c.

2. Глоба-Михайленко И.Д. Модель организации трудового воспитания в муниципальном бюджетном учреждении дополнительного образования «Эколого-биологический центр имени С.Ю. Соколова» г. Сочи. - Сочи: 2017. - 12 с.

3. Гузеев В.В. Образовательная технология XXI века: деятельность, ценности, успех. - М: Центр «Педагогический поиск», $2009-230$ с.

4. Инновационные педагогические технологии : Материалы II Международной научной конференции. - Казань: Бук, 2015. - 78 с.

5. Мамардашвили М.К. Философские чтения,.СПб: Азбука-классика, 2002.-822c.

6. Новые информационные технологии в образовании // Материалы международной научнопрактической конференции. - Екатеринбург: РГППУ, 2012. - 538 с.

7. Шаповалов М.В. Образовательный мониторинг в управлении качеством подготовки специалисто в учреждениях среднего профессионального образования. - Ставрополь : СКИПКРО, 2005. - 72 с.

8. Яковлев С.В. Воспитание ценностных оснований личности. - М.: Инфра , 2017. 147c. 


\section{SECTION III. MATHEMATICS}

\section{Kandalova M.A. \\ Mathematical methods and their application in the sectors of the national economy (case study of agribusiness)}

Moscow State University of Food Production

(Russia, Moscow)

doi $10.18411 / g q-15-10-2021-09$

\section{Abstract}

Agribusiness is one of the most important areas in the economic structure of the Russian Federation, and its research is significant because of the country's dependence on food supplies. At the same time, manufacturing is characterized by a rather complex technological cycle and has many economic entities involved in the sale of products. Under these conditions, the construction of an optimal management system of an agricultural enterprise cannot be carried out without formed practical analysis models that help to identify the patterns of their operation. At the same time, it is the agrarian sector that seems to be the standard for the application of mathematical methods, making it possible to account for the laws and trends that have formed during forecasting the development of this and other sectors. The mathematical analysis of statistical data in the agricultural sector is based on various models and methods, among which the preference is given to economic and mathematical or simulation modeling. Using traditional mathematical models during static observation, trends and forecasts of the development of the sector have been built, the study of which is the objective of this paper. trend.

Keywords: agricultural industry, trends, dynamics, growth, mathematical methods,

\section{Аннотация}

Агробизнес является одной из важнейших областей в экономической структуре Российской Федерации и значимость его исследования обусловлена зависимостью страны от продовольственных запасов. В тоже время промышленное производство характеризуется довольно сложным технологическим циклом и имеет множество субъектов экономики, участвующих в реализации продукции. В этих условиях построение оптимальной управленческой системы аграрного предприятия не может производиться без наличия сформированных практических моделей анализа, способствующих выявлению закономерностей их функционирования. В то же время именно аграрная сфера представляется эталонной для применения в ней математических методов, которые позволяют учитывать законы и сформировавшиеся тенденции при разработке прогнозов развития этой и других отраслей. Математический анализ статистических данных аграрной сферы строится на различных моделях и методах, среди которых преимущество отдается экономико-математическому или имитационному моделированию. Посредством традиционных математических моделей при проведении статического наблюдения строятся тренды и прогнозы развития отрасли, на изучение которых нацелена данная статья.

Ключевые слова: аграрная промышленность, тенденции, динамика, рост, математические методы, тренд.

Basic part.

Mathematical methods in the field of the agricultural sector are used quite often. In this case, the research database can be agribusiness enterprises of separate regions, 
municipalities, and the entire country. The analysis is carried out using the methods of absolute and relative differences, as well as by identifying the average annual growth rates of sectoral indicators and their growth [1]. The purpose of this analysis is to identify factors and trends that contribute to the development of management decisions aimed at improving the efficiency of the sector in the future. In this case, the series of dynamics of the number of employees in the sector compared to similar sectors, as well as the volume of industrial output, are the paramount parameters of assessment. Thus, Figure 1 shows the dynamics of the number of sector employees for the period of 2003-2020.

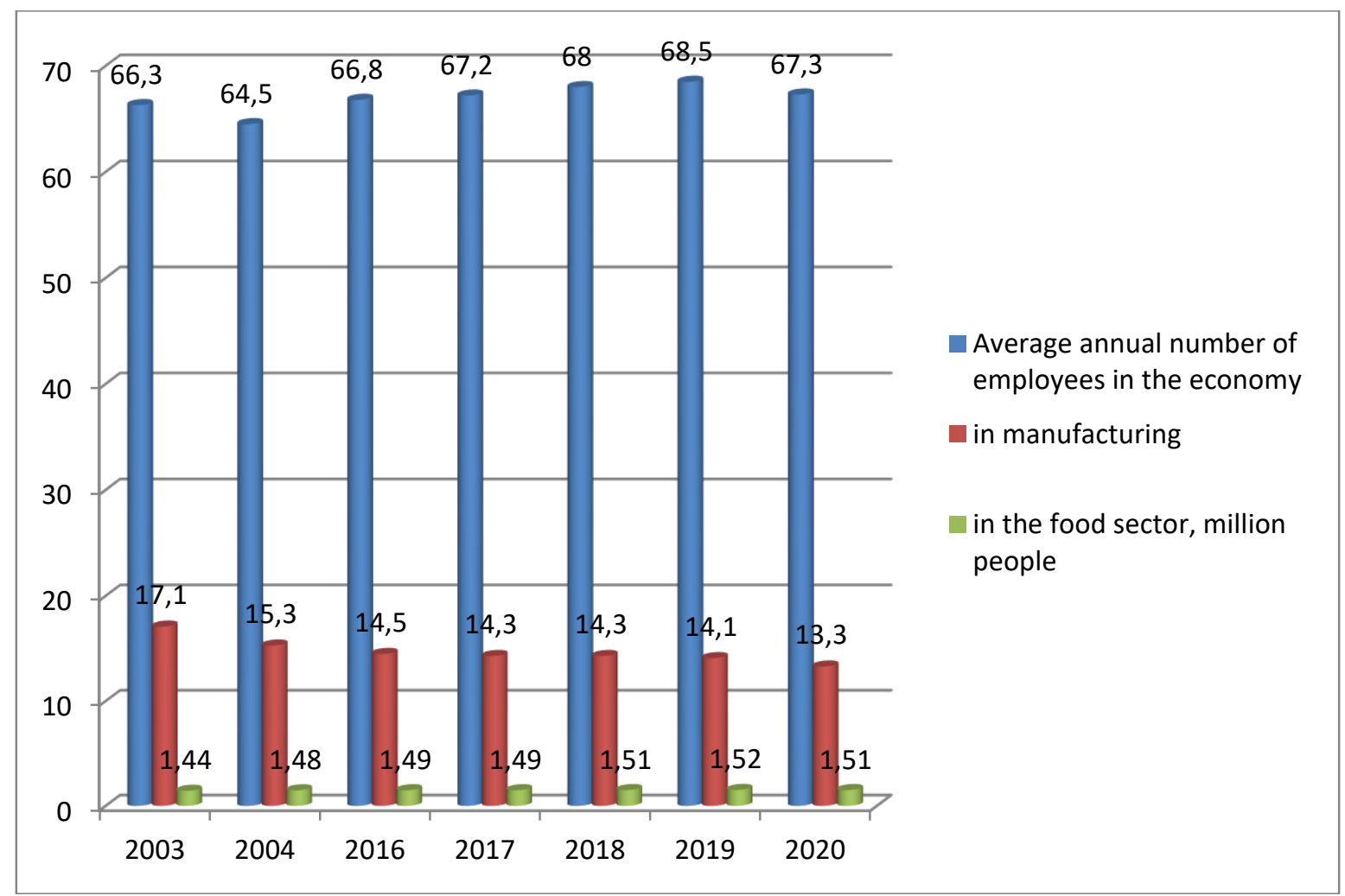

Figure 1. Dynamics of the number of employees in the industry for the period of 2003-2020, million people Source: compiled by the author based on [2]

Figure 1 shows that in 2020, due to the crisis, there was a decrease in the number of sector employees. In general, the number of employees in the sector during 2003-2019 steadily increased, despite the decline in other industries in some periods. However, 2020 negatively affected all industrial enterprises, which cut the number of employees, some of whom lost their jobs due to bankruptcy of companies or layoffs. The indicator of the share of the food sector employees in the total number of people employed in the economy and in manufacturing as a whole is of interest.

The share of employees in the food sector is about $10 \%$ of all employed in manufacturing, which indicates the importance of this sector. Gradually, there is a positive trend in the number of employees in the sector, which indicates the expansion of the food sector in Russia.

The share of people employed in the food sector has not significantly increased in relation to the entire economic structure of the country, while in manufacturing, there has been a rather tangible increase in this indicator, which allows concluding that the development of the sector is stable. Most of the staff cuts in 2020 affected manufacturing as a whole; in the food sector, they were not so significant.

Next, a comparative analysis of the number of enterprises in manufacturing general and in the food sector in particular has been made (Figure 2). 


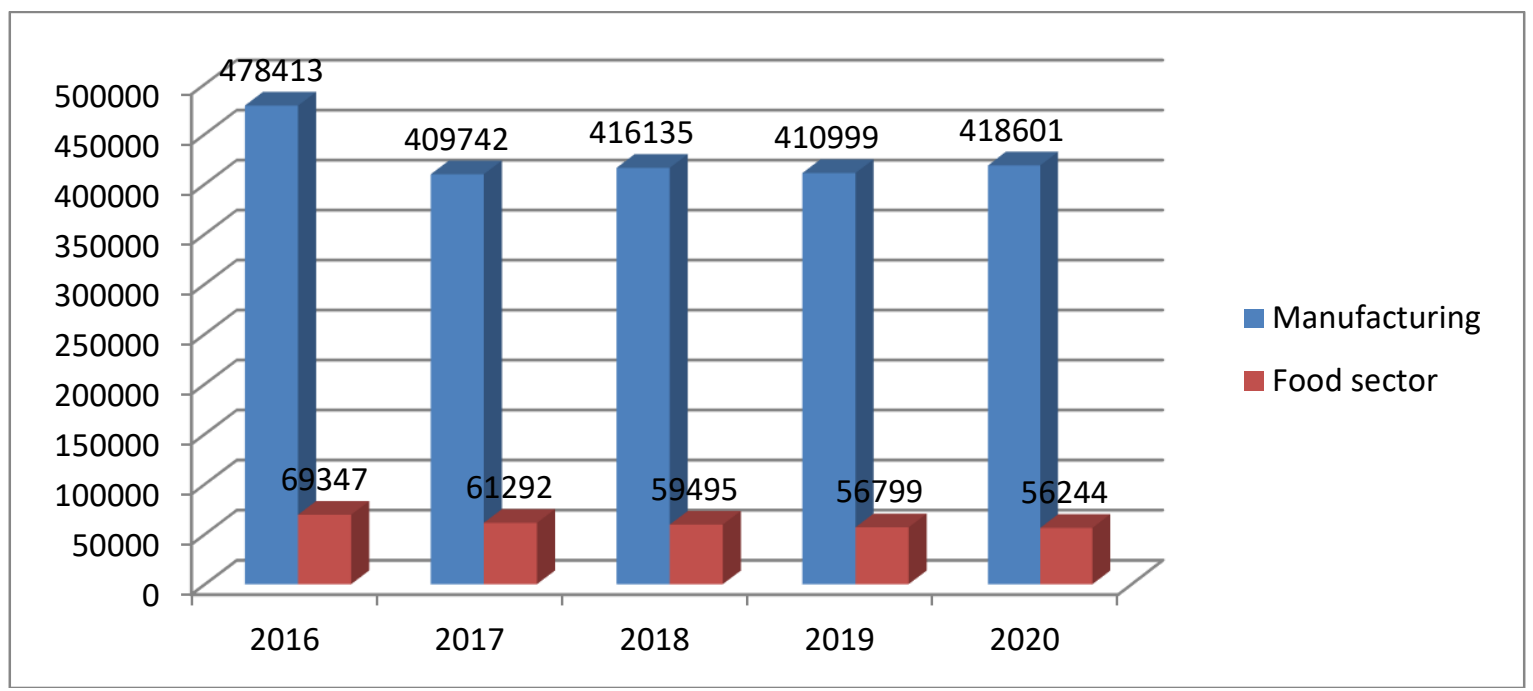

Figure 2. Dynamics of the number of enterprises in manufacturing as a whole and in the agricultural sector Source: compiled by the author based on [2]

Compared to 2016, the number of enterprises in manufacturing decreased, as well as in the food sector. However, this does not indicate a deterioration in the sectoral performance. These trends are associated with an increase in the integration movements towards mergers of small companies into large holdings, since it is becoming more and more difficult for small businesses to withstand difficult market conditions.

An important indicator in statistical analysis, which makes it possible to identify sectoral trends more clearly, is the dynamics of the production output in physical and value terms.

Next, it is necessary to compare the dynamics of industrial and food production in comparison by types of products (Figure 3 ).

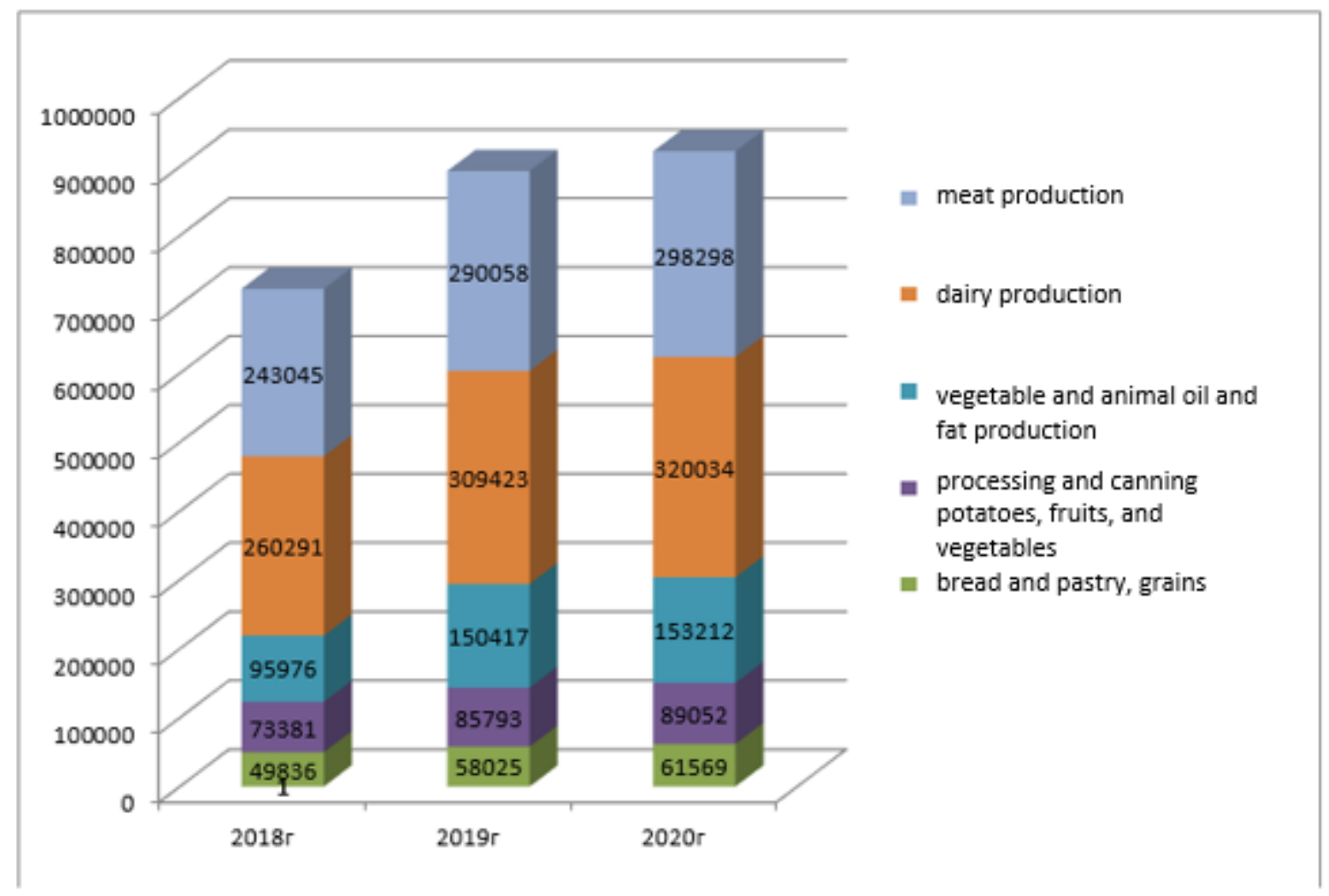

Figure 3. Dynamics of production of the entire manufacturing industry and the agricultural sector in comparison by types of products, million rubles Source: compiled by the author based on [2] 
Figure 3 shows that, despite the crisis, in 2020 there was an increase in the total volume of food production. This is due to the increase in food prices, which was observed in 2020, as well as in the demand for food in view of the economic crisis. Most of the sales are dairy products and meat. The share of vegetable fats and oils is also high.

Next, an analysis of the ratio of the growth rates of the volume of production in the entire manufacturing industry and in the food sector should be carried out. The data for analysis are shown in Figure 4.

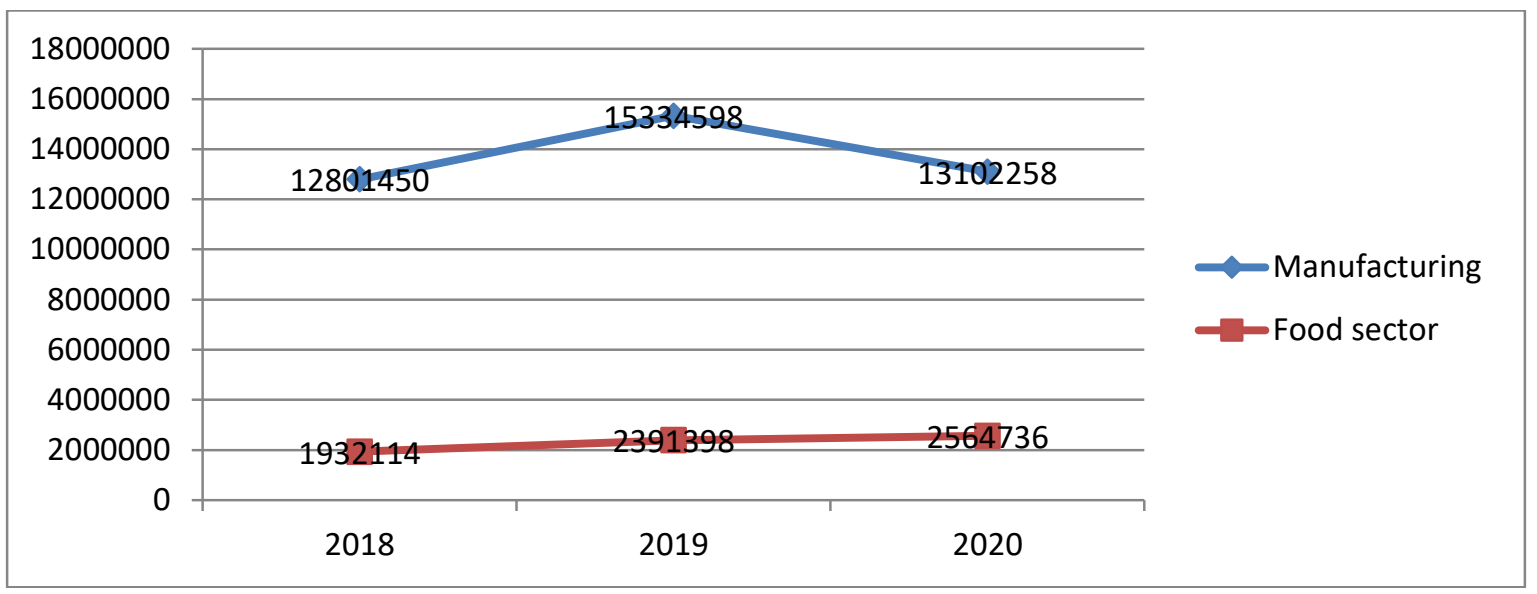

Figure 4. Ratio of output growth rates in manufacturing and the agricultural sector, million rubles Source: compiled by the author based on [2]

This graph proves the above conclusion that despite the economic crisis in 2020, the food sector has developed quite steadily. There was an increase in the volume of production output, despite the fact that there was a significant decline in manufacturing.

In conclusion, it is logical to present the dynamics of financial results obtained in the entire manufacturing and the food sector in particular, which is shown in Figure 5.

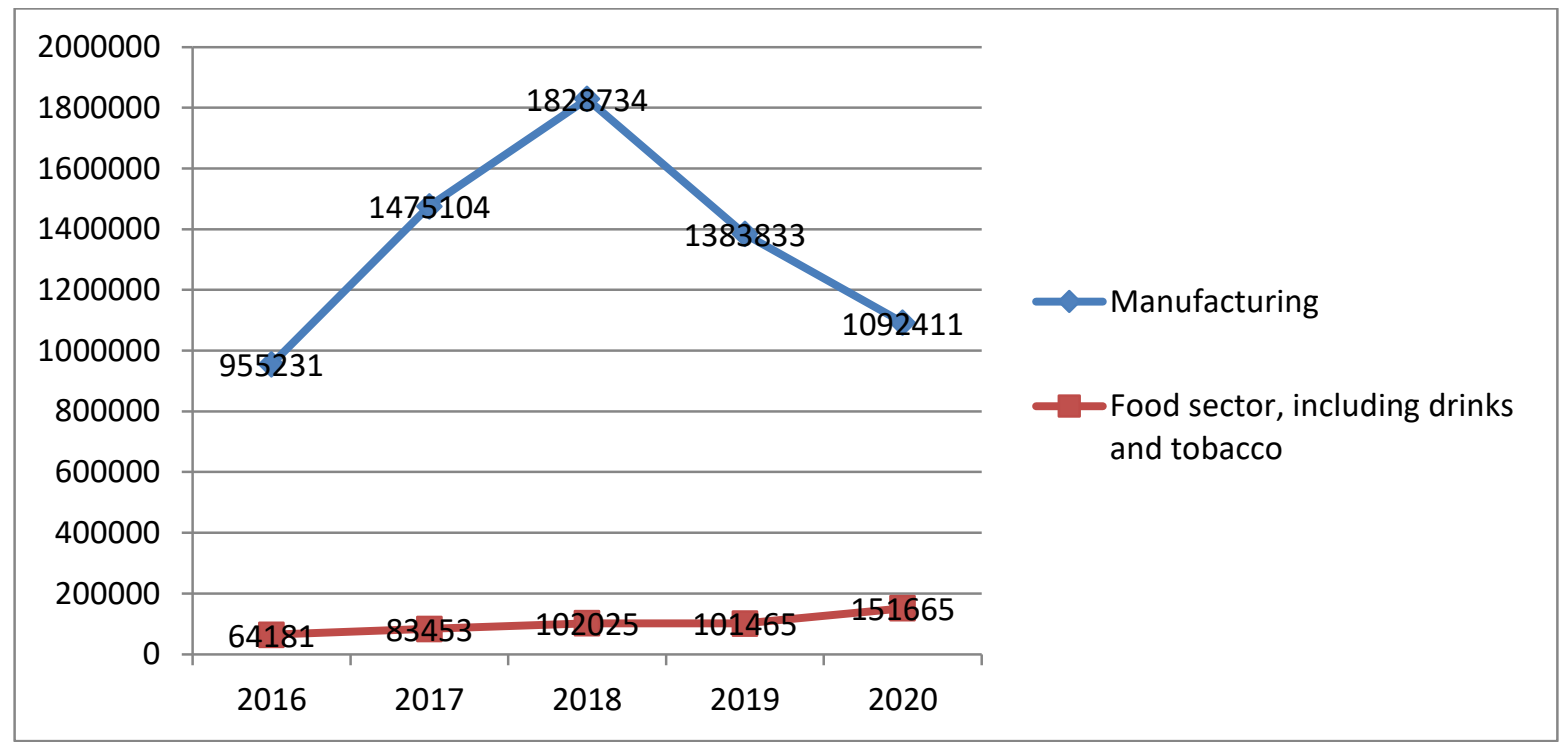

Figure 5. Ratio of growth rates in financial performance in manufacturing and agribusiness, million rubles Source: compiled by the author based on [2]

It can be concluded that, despite the general decline in profits due to the crisis in the economy, there is a slight increase in the financial performance of the food sector. To confirm the indicated data, it is worth presenting an analysis of the indicators of the profitability of enterprises. 
The main indicator of corporate efficiency is profitability, the analysis of which is shown in Figure 6.

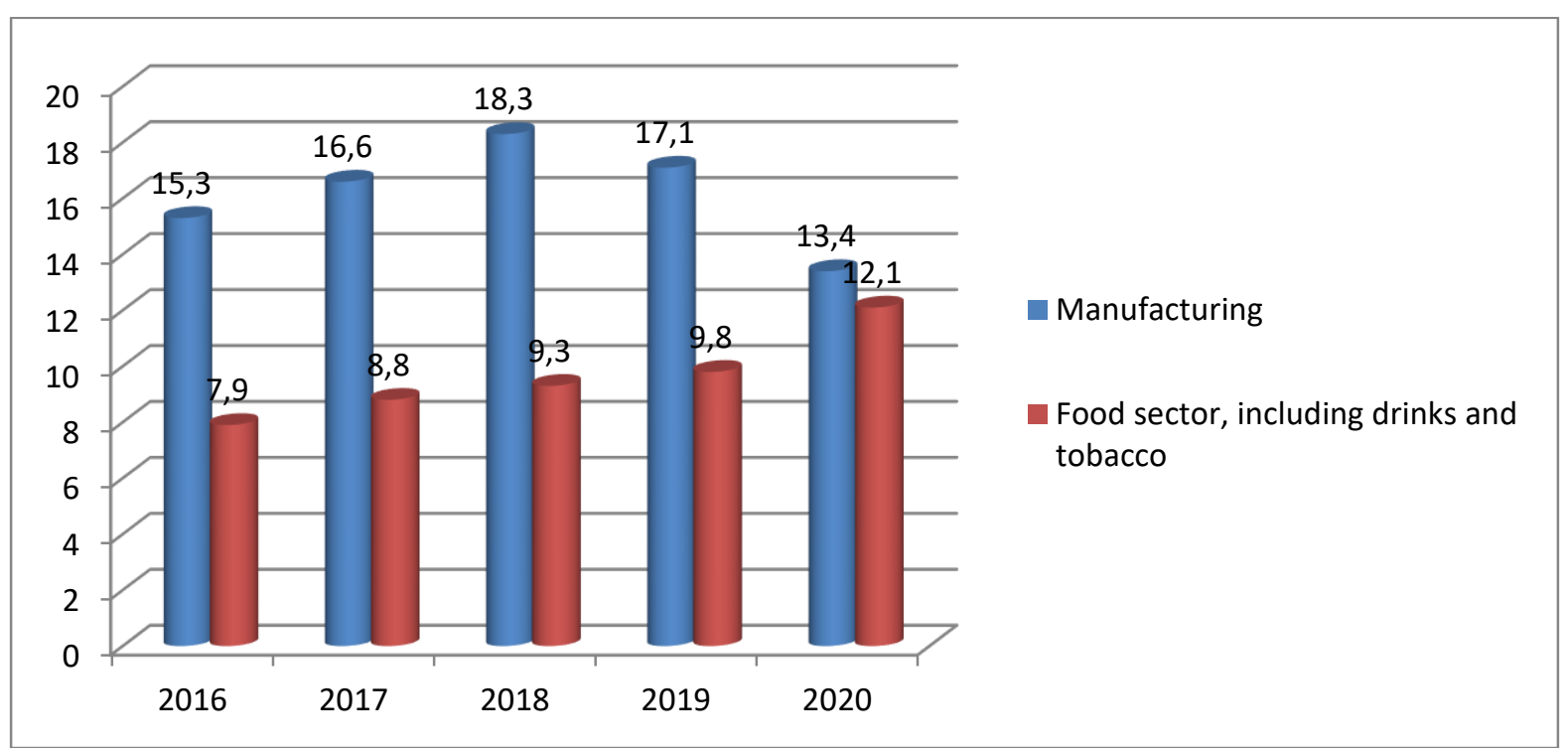

Figure 6. Dynamics of efficiency indicators of industrial and agribusiness enterprises, \% Source: compiled by the author based on [2]

Figure 6 proves that, while the average level of profitability in manufacturing as a whole decreases, in the food sector, on the contrary, there is a slight increase in 2020, which is associated with an increase in sales and in prices in the reporting year in comparison with the baseline in the food sector in Russia as a whole.

The use of mathematical models in statistics allows identifying clearer trends and determining the degree of influence on an industry of particular factors [3]. A factor analysis of changes in the volume of production in 2020 compared to 2019 has been carried out as follows.

The volume of production output was:

$2019 \mathrm{y}=2,398$ billion rubles.

$2020 \mathrm{y}=2,564$ billion rubles.

Thus, the volume of production in 2020 increased compared to 2019 by 166 billion rubles $(2,564-2,398)$ or by $21.3 \%(2,564: 2,398=1.069)$.

Now, one can find the influence of factors on the overall change in the volume of production output by the food sector. The factor model has the form [4]:

$$
\mathrm{Y}=\mathrm{N} \times \mathrm{d} \times \mathrm{T} \text {, }
$$

where $\mathrm{N}$ is the total number of manufacturing staff;

$\mathrm{D}$ is the proportion of workers in the total number of manufacturing staff;

$\mathrm{T}$ is the labor productivity of workers.

Now, it is possible to calculate labor productivity in 2019 and 2020.

$2019 \mathrm{~T} 0=2,398: 68.5=35$ million rubles per person

$2020 \mathrm{~T} 1=2,564: 67.3=38.1$ million rubles per person

1. Due to the increase in the number of manufacturing staff, the volume of production increased by 33.9 billion rubles.

$\Delta \mathrm{Y}(\mathrm{N})=\Delta \mathrm{N} \times \mathrm{d} 0 \times \mathrm{T} 0=(68.5-67.3) \times 0.807 \times 35=33.9$ billion rubles

2. Due to the decrease in the share of workers in the total number of manufacturing staff, the volume of production output decreased by 32.9 billion rubles.

$\Delta \mathrm{Y}(\mathrm{d})=\mathrm{N} 1 \times \Delta \mathrm{d} \times \mathrm{T} 0=67.3 \times(0.793-0.807) \times 35=-32.9$ billion rubles

3. Due to the increase in labor productivity, the volume of production output increased by $183,106.0$ million rubles. 
$\Delta \mathrm{Y}(\mathrm{T})=\mathrm{N} 1 \times \mathrm{d} 1 \times \Delta \mathrm{T}=67.3 \times 0.793 \times(38.1-35)=165.4$ billion rubles

$\Delta \mathrm{Y}=\Delta \mathrm{Y}(\mathrm{N})+\Delta \mathrm{Y}(\mathrm{d})+\Delta \mathrm{Y}(\mathrm{T})=33.9-32.9+165.4=166.4$ billion rubles

Thus, the greatest share in the increase in sales proceeds belongs to the influence of increased labor productivity.

So, through the use of a mathematical model, it was revealed that the main factor that influenced the volume of sectoral output was productivity growth.

In order to make a forecast for the sector development, one can smooth the considered time series using the 3-year moving average method [5]. The calculation results are presented in Table 1.

Table 1

Smoothing time series using the 3-year moving average method

\begin{tabular}{|c|c|c|c|}
\hline Year & $\begin{array}{c}\text { Production volume in } \\
\text { 2017 prices, billion } \\
\text { rubles }\end{array}$ & $\begin{array}{c}\text { Moving total } \\
y 1+y 2+y 3\end{array}$ & $\begin{array}{c}\text { Moving average } \\
(y 1+y 2+y 3): 3, \text { billion rubles }\end{array}$ \\
\hline 2016 & 1,674 & - & - \\
\hline 2017 & 1,885 & 5,491 & $1,830.3$ \\
\hline 2018 & 1,932 & 6,209 & $2,069.6$ \\
\hline 2019 & 2,392 & $6,889-$ & $2,296.3$ \\
\hline 2020 & 2,565 & & \\
\hline
\end{tabular}

Source: compiled by the author based on [2]

According to Table 1, it can be concluded that there is a trend towards an increase in the level of food production since 2018 .

In the authors' opinion, analytical alignment is a more perfect technique for revealing a general tendency in the time series [6]. When analyzing the general trend by analytical alignment, it is worth taking into account the levels of the time series, which can be with a certain degree of approximation to certain mathematical functions. Thus, on the basis of theoretical analysis, it is possible to identify the nature of the sector's development over time.

Next, this series of dynamics can be aligned according to the equation of a straight line:

$$
\mathrm{Yt}=\mathrm{a} 0+\mathrm{a} 1 \times \mathrm{t},
$$

where a0, a1 - parameters of the straight line equation; $\mathrm{t}$ - year legend.

The parameters of the equation of the straight line are found by the least-squares method using a system of linear equations.

$$
\begin{gathered}
\mathrm{a} 0 \times \mathrm{n}+\mathrm{a} 1 \times \sum \mathrm{t}=\sum \mathrm{y} \\
\mathrm{a} 0 \sum \mathrm{t}+\mathrm{a} 1 \sum \mathrm{t}^{2}=\sum \mathrm{ty}
\end{gathered}
$$

The calculated parameters of the straight line equation are displayed in Table 2.

Table 2

Calculation of the parameters of the straight line equation

\begin{tabular}{|c|c|c|c|c|c|c|}
\hline Year & $\begin{array}{c}\text { Year legend, } \\
t\end{array}$ & $\begin{array}{c}\text { Production } \\
\text { volume, billion } \\
\text { rubles, } y\end{array}$ & $t^{2}$ & $T \times y$ & $Y p$ & $(y-y p)^{2}$ \\
\hline 2016 & -2 & 1,674 & 4 & 4 & $-3,348$ & 5,022 \\
\hline 2017 & -1 & 1,885 & 1 & 1 & $-1,885$ & 3,770 \\
\hline 2018 & 0 & 1,932 & 0 & 0 & 0 & 1,932 \\
\hline 2019 & 1 & 2,392 & 1 & 1 & 2,392 & 0 \\
\hline 2020 & 2 & 2,565 & 4 & 4 & 5,130 & $-2,565$ \\
\hline$\Sigma$ & 0 & & 10 & & & \\
\hline
\end{tabular}

Source: compiled by the author based on [2]

The straight line equation has the form $\mathrm{Yt}=520.96+72.91 \mathrm{t}$.

According to the straight line equation, the conclusion can be drawn that with each subsequent year, the output of the food sector enterprises will increase. 
So, the case study of an analysis of the main indicators of the development of the agricultural sector allows concluding on the importance of mathematical methods in doing such analysis. At the same time, it is possible to calculate predicted values, as well as identify factors that have become key in certain trends.

$$
* * *
$$

1. Dolgova, V.N., Medvedeva, T.Yu. Theory of statistics. Textbook and workshop for academic undergraduate studies. Moscow: Yurait, 2019. 246 p.

2. Business climate in manufacturing in 2020. Moscow: NRU HSE, 2020. 24 p.

3. Malykh, N.I. Statistics. Volume 2. Socio-economic statistics. Textbook and workshop for academic undergraduate studies. Moscow: Yurayt, 2017. 474 p.

4. Statistics with elements of econometrics. Textbook for open source software. Part 2 / ed. Kovalev V.V. Moscow: Yurayt, 2019. 348 p.

5. Trofimov, A.G. Mathematical statistics. Textbook for secondary professional education. Moscow: Yurayt, 2019. 260 p. 


\section{SECTION IV. BIOLOGY}

\section{Шмакова О.В., Концевая С.Ю. \\ Сравнительные аспекты информативности ультразвуковой и рентген диагностики при уролитиазе у мелких домашних животных}

ФГБОУ ВО Белгородский ГАУ

(Россия, Майский)

doi $10.18411 / g q-15-10-2021-10$

\section{Аннотация}

В настоящее время заболевания органов мочевыводящей системы мелких домашних животных одна из самых распространенных проблем в ветеринарии. В связи с разнообразием заболеваний, имеющих множество сходных клинических проявлений, всегда остается актуальным вопрос правильной и своевременной диагностики различных заболеваний почек, мочеточников, мочевого пузыря и уретры. В распоряжении современной ветеринарии находятся современные инструментальные методы диагностики, дающие возможность быстро и точно провести исследование органов мочевой системы животных, такие как ультрасонография (УЗИ), рентгенография, компьютерная томография . Однако и стоимость данных методов диагностики достаточно высока. Из-за кризиса и общего снижения уровня обеспеченности владельцев животных встает немаловажный вопрос о том, какие из инструментальных методов диагностики необходимы в первую очередь. В данной статье обсуждается целесообразность применения УЗИ и рентгенографии, а так же обосновывается необходимость их применения при диагностике такого распространенного заболевания мочевыводящих путей животных, как уролитиаз.

Ключевые слова: мелкие домашние животные, методы диагности, уролитиаз, ультрасонография мочевого пузыря, рентгенография мочевых путей.

Актуальность. Среди заболеваний органов мочевыводящей системы мелких домашних животных по частоте встречаемости уролитиаз занимает одно из первых мест и сравним по количеству летальных исходов с патологиями сердечно-сосудистой системы, травмами, онкологией. У собак возникновение уролитиаза связано с инфекциями нижних мочевыводящих путей и с генетической предрасположенностью. У кошек данное заболевание связано с особенностями концентрации мочи и анатомическим строением мочевыводящего тракта. Диагностируется чаще у котов, что связано со строением уретры у самцов. Узкая дистальная часть уретры способствует скоплению солей в этом участке с образованием солевой пробки, смешанной белковосолевой пробки, что приводит к обструкции уретры. У кошек уретра достаточно широкая и зачастую заболевание протекает скрыто, не вызывая обструкции уретры. Сходны клинические проявления болезни у хорьков, морских свинок и других мелких домашних животных: гематурия, дизурия, поллакиурия, обструктивная анурия, общее угнетение, снижение аппетита, потеря веса при длительном течении и позднем обращении владельцев за помощью.

Причины возникновения мочевых конкрементов многообразны. К ним относятся причины экзогенные, эндогенные.

К экзогенным факторам относятся состав питьевой воды, тип кормления и состав используемых кормов, количество потребляемой воды (многие кошки, в связи с их способностью концентрировать мочу потребляют малое количество воды, что приводит к наступлению порога концентрации, когда складываются благоприятные 
условия для образования кристаллов) климатические способствующие факторы (например переохлаждение или перегрев).

К эндогенным факторам можно отнести аномалии строения мочевых путей, вызывающие затруднение отхождения мочи, изменение обмена веществ, приводящее к ощелачиванию мочи, наличие сосудистых аномалий печени (шунтов), что приводит к нарушению синтеза пуринов, воспалительные процессы в мочевых путях, вызывающие нарушения экскреции и реабсорбции мочи и ее составляющих, доказана роль отдельных микроорганизмов, расщепляющих мочевину, что приводит к ее ощелачиванию и выпадению солей - фосфатов; генетические факторы (например, предрасположенность к образованию конкрементов оксалата кальция) гиперфункция паращитовидной железы, приводящая к нарушению фосфорно-кальциевого обмена и др.

Матричная теория образования уролитов [...] состоит в том, что центром образования кристаллов мочевых солей всегда является некая матрица -белковая структура (например мертвая клетка) на которой откладываются соли и в дальнейшем происходит рост конкремента. Ядром камней всегда служит органическая субстанция, которая либо является основой самого уролита (например цистинового), либо просто играет роль центра кристаллизации.[...] Матрицей могут служить и болезнетворные микроорганизмы, присутствующие в моче.

Материал и методы исследования. Исследование и анализ данных обследования животных проводились на базе ветеринарной клиники «Неболейка», г.Чехов, Московская область. Исходя из данных исследований только за период с августа 2018года по июль 2021 года, на прием с признаками нарушения мочеиспускания: поллакиурией, гематурией, анурией, с сопутствующими угнетением, отказом от корма поступило 136 животных, из них 9\% составили собаки, 2\% другие мелкие животные и $89 \%$ кошки, из них коты $54 \%$.

Таблииа 1

\begin{tabular}{|c|c|c|c|c|c|c|}
\hline $\begin{array}{c}\text { Вид } \\
\text { животного }\end{array}$ & пол & $\begin{array}{c}\text { Количество } \\
\text { (гол) }\end{array}$ & ХБП & уролитиаз & ицистит & $\begin{array}{c}\% \\
\text { встречаемости } \\
\text { среди других } \\
\text { видов } \\
\text { животных }\end{array}$ \\
\hline \multirow[t]{2}{*}{ собаки } & суки & 8 & 1 & 4 & 8 & $6 \%$ \\
\hline & кобели & 4 & 0 & 2 & 4 & $3 \%$ \\
\hline \multirow[t]{2}{*}{$\begin{array}{c}\text { морские } \\
\text { свинки }\end{array}$} & самки & 1 & & 1 & 1 & $1 \%$ \\
\hline & самųь & 0 & 0 & 0 & 0 & 0 \\
\hline \multirow[t]{2}{*}{ кролики } & самки & 0 & 0 & 0 & 0 & 0 \\
\hline & caмu̧bl & 1 & 0 & 1 & 1 & $0.5 \%$ \\
\hline \multirow[t]{2}{*}{ кошки } & самйbl & 73 & 35 & 46 & 73 & $54 \%$ \\
\hline & самки & 48 & 20 & 5 & 48 & $35 \%$ \\
\hline хорьки & самка & 1 & 0 & 1 & 1 & $0.5 \%$ \\
\hline Итого: & & 136 & 56 & 60 & 135 & $100 \%$ \\
\hline
\end{tabular}

Всем животным проводились общие методы диагностики (физикальный осмотр, забор анализов мочи и крови) и инструментальные методы диагностики, в том числе ультразвуковое исследование органов мочевыводящей системы и рентгенография брюшной полости.

Стандартный алгоритм диагностики уролитиаза включает в себя:

1. сбор анамнеза;

2. физикальный осмотр;

3. сбор анализов (ОКА крови, биохимический анализ крови, анализ мочи, посев мочи, анализ состава уролитов);

4. УЗИ брюшной полости; 
5. рентгенография брюшной полости;

6. при подозрении на наличие неоплазии мочевыводящих путей - КТ.

Компьютерная томография, как достаточно дорогостоящий метод исследования может быть предложен при подозрении на обструкцию мочевых путей новообразованиями, для уточнения локализации новообразования и определения характера роста новообразования и вовлеченности в него рядом лежащих структур и тканей.

Для исследований поступивших на осмотр животных с признаками нарушения мочеиспускания в нашей клинике использовались следующие методы.

Сбор анамнеза и физикальный осмотр. Мы отмечали, что клинические проявления уролитиаза , если заболевание не сопровождается обструкцией мочевыводящих путей разнообразны и сходны с другими распространенными заболеваниями мочевыводящих путей, такими как нефрит, уретрит, новообразования мочевыводящих путей: дизурия, гематурия, странгурия, вокализация, частое вылизывание в области половых органов, боль при мочеиспускании, снижение аппетита или полный отказ от еды, стремление спрятаться в укромных местах, залеживание, иногда повышение или понижение температуры тела, вялость, боль при попытках владельцев потрогать брюшную стенку питомца.

При возникновении обструкции клинические проявления более специфичны: длительное нахождение в позе мочеиспускания без появления мочи, (зачастую владельцы кошек принимают эту позу за позу при дефекации и пытаются самостоятельно лечить запор, которого нет, что приводит к затягиванию заболевания и ухудшению состояния животного); увеличение объема живота, обнаружение переполненного мочевого пузыря при пальпации живота. Подобные клинические проявления могут возникать и при других заболеваниях мочевыводящих путей, например при идиопатическом цистите или при детрузорносфинктерной диссинергии, при отеке стенки мочевого пузыря при остром воспалении, при значимом новообразовании стенок мочевого пузыря. Такие же признаки наблюдаются и у собак, что так же не всегда связано с наличием уролитов. Например, идиопатический цистит кошек, протекающий с признаками, схожими с обструкцией уретры, протекает вообще без наличия кристаллов в моче и без образования механической обструкции уретры конкрементами. Катетеризация мочевого пузыря при собственно ИЦК не оправдана и несет в себе опасность заноса инфекции в мочевой пузырь и, соответственно, опасность осложнения течения заболевания.

В связи с этим, возникает острая необходимость в дополнительных инструментальных методах диагностики, которые помогли бы четко разграничить заболевания мочевых путей со сходными клиническими признаками, для постановки точного диагноза, выявления наличия или отсутствия сопутствующего заболевания почек и разработки правильной тактики лечения.

Общий клинический и биохимический анализы крови позволяют выявить наличие или отсутствие лейкоцитоза, анемии, выявить сопутствующие нарушения функции почек, их степень, заболевания печени, нарушения функции ЖКТ, выявить нарушения электролитного баланса крови, такие как гипер- или гипокальцемию, гиперфосфатемию, и др. нарушения гомеостаза.

Общий анализ мочи и мочевого осадка позволяет выяснить изменения свойств мочи, которые могут служить причиной образования уролитов (изменение $\mathrm{pH}$ мочи в щелочную сторону, повышение удельного веса мочи), выявить признаки сопутствующего поражения мочеточников, почек - наличие эпителиальных цилиндров, переходного и почечного эпителия, наличие лейкоцитов, эритроцитов и их 
относительное количество, наличие нитритов, печеночных ферментов в моче, наличие кристаллурии.

Посев мочи необходим для выявления болезнетворных микроорганизмов и их чувствительности к антибиотикам. Хотя по некоторым данным посев мочи во многих случаях не дает роста микроорганизмов, однако, это не исключает наличия инфекции мочевых путей.

Уролиты сами по себе, особенно рыхлые по структуре, являются средой для размножения микроорганизмов, что является причиной хронической инфекции мочевого пузыря (и почек). И, в дальнейшем, бактерии, мигрируя в верхние отделы мочевыделительной системы могут вызывать вторичное инфекционное заболевание почек (восходящая инфекция почек).

В данной статье, наряду с общим описанием различных методов инструментальной диагностики , более подробно рассматриваются два важных инструментальных метода диагностики уролитиаза: ультрасонография и рентгендиагностика, т.к эти два вида исследования доступны в большинстве клиник нашей страны и должны активно использоваться.

Ультрасонографическое исследование: результативный современный метод, который позволяет оценить внутреннюю эхографическую структуру почек, мочеточников, мочевого пузыря, уретры, выявить наличие пескообразных солей и крупных конкрементов в мочевых путях, выявить признаки обструкции уретры, локализацию конкрементов, их размер, выявить возможные новообразования органов мочевыделительной системы, возможные аномалии строения мочевых путей (например - дивертикул мочевого пузыря) и так далее. Чувствительность метода высока, специфичность может быть несколько ниже, т.к. сходную визуализацию при ультрасонографии могут иметь уролиты рыхлой структуры, сгустки крови с включенными в тело сгустка солями, слепки пескообразных солей и слизи.

Рентгеновское исследование (и его разновидности): так же незаменимый метод исследования мочевыделительной системы при подозрении на уролитиаз. Однако, стоит заметить, что рентгеновские снимки брюшной полости могут дать ложноотрицательные результаты при наличии нерентгенконтрастных уролитов. В подобных случаях используется внутривенная контрастная экскреторная урография, или ретроградная урография, с использованием препарата ОМНИПАК. Данные методы исследования помогают определить локализацию уролитов в участках мочевыводящих путей, недоступных для УЗИ (например в полости таза, где тазовые кости экранируют уретру), или подтвердить минерализацию паренхимы почек, если ультрасонография дала сомнительный результат. Рентгеновское исследование с использованием рентгенконтрастных веществ помогает выделять рентген-прозрачные конкременты или обструкции не связанные с уролитами (например - интрамуральную эктопию мочеточника, или новообразование уретры, стриктуры уретры, мочеточников, и т.д.).

Нельзя не упомянуть и еще об одном важном методе диагностики: ретроцистоэндоскопия, ассистированная чрезкожная цистоэндоскопия (по данным Центра ветеринарной малоинвазивной хирургии и диагностики «Комондор» Журнал: №1 - 2014). Данные методы используются для визуализации и удаления уролитов малоинвазивным методом, для внутрипузырного дробления уролитов. Эндоскопия черезвычайно важна в оценке степени повреждения слизистой мочевого пузыря в связи с четкой визуализацией внутренней поверхности мочевого пузыря и возможностью взятия биопсии для точной лабораторной диагностики заболеваний стенки мочевого пузыря и уретры.

Представим несколько примеров из нашей практики, иллюстрирующие возможности ультрасонографии и рентгеновского обследования. 


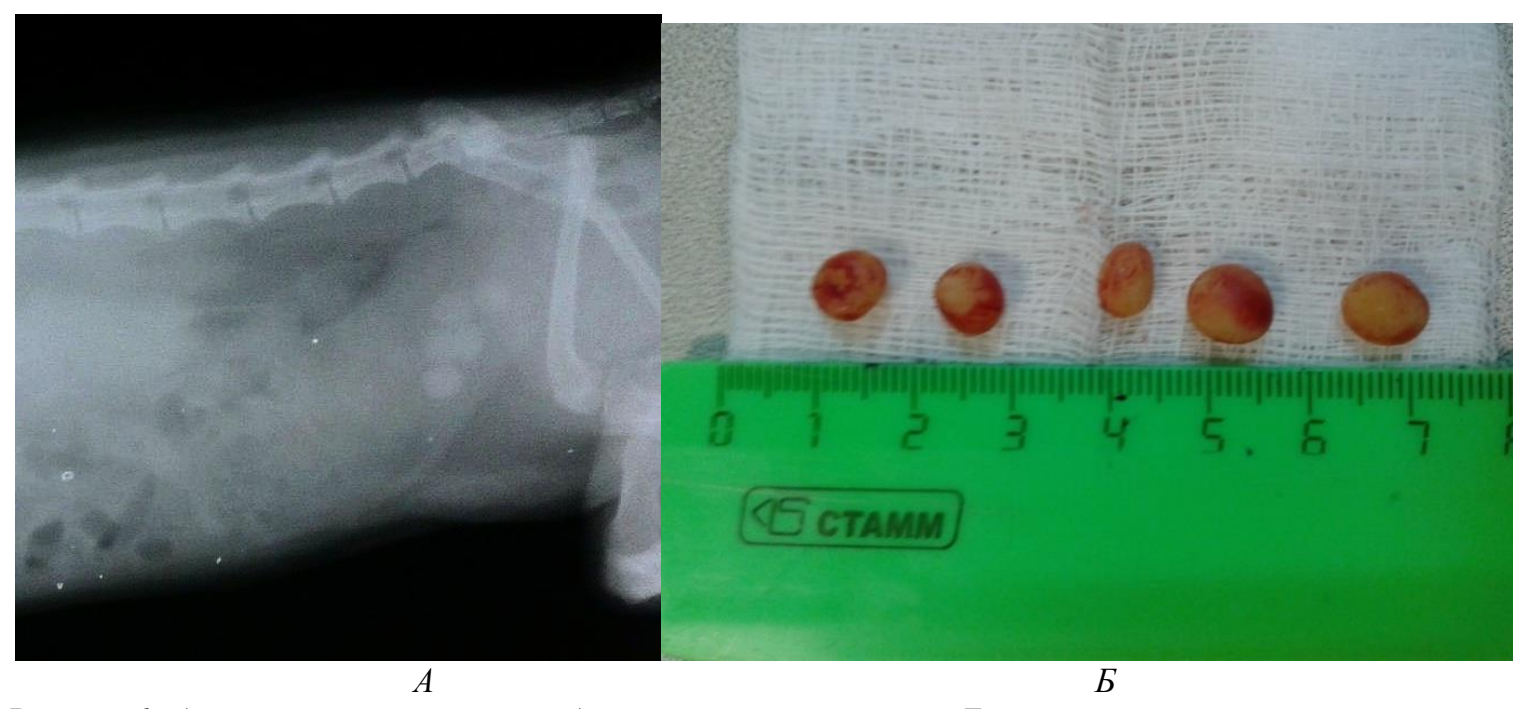

Рисунок 1. А - рентгеновский снимок брючной полости хорька, Б - уролиты, извлеченные из мочевого пузыря самки хорька

На рис.1 представлен рентген брюшной полости хорька (самка, возраст 2 года), стерилизована) Хорошо визуализируются мочевые конкременты в полости мочевого пузыря.

На рис.2 представлено фото уролитов, извлеченных из мочевого пузыря при уретротомии того же хорька. Тип уролитов - струвиты. (Тип уролитов подтвержден лабораторными исследованиями в лаборатории...)

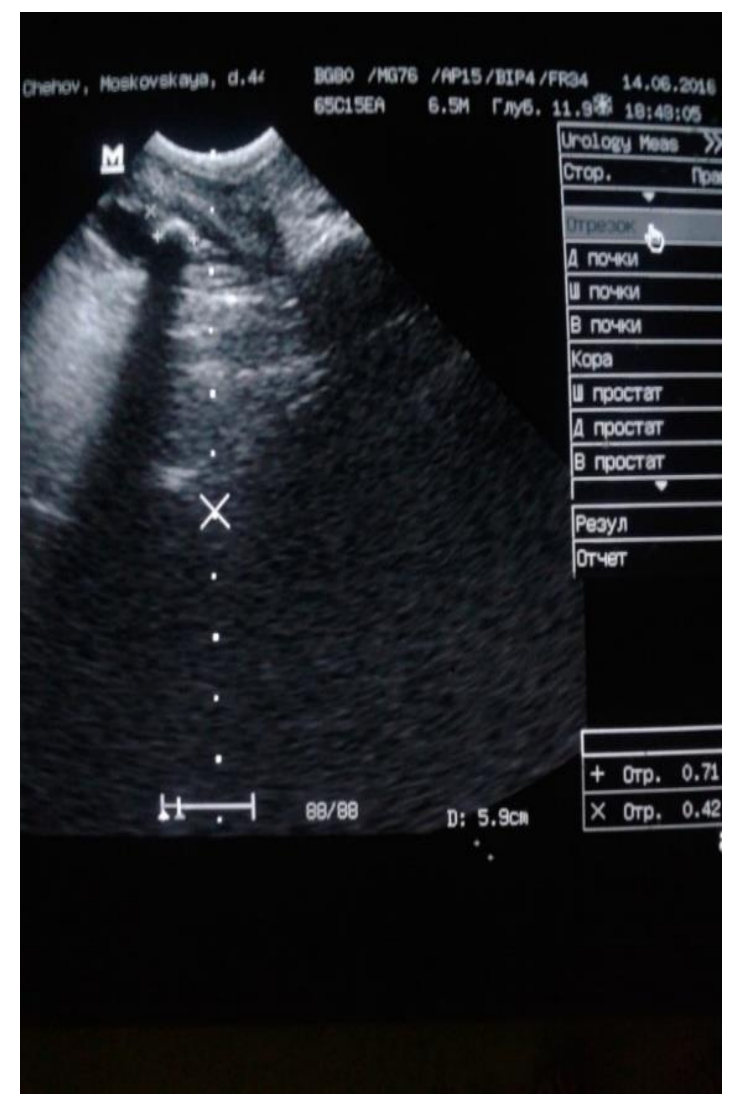

Рисунок 2. Фото с экрана при проведении ультрасонографии мочевого пузыря самки морской свинки. Возраст 4 года

На рис.2 представлен снимок с экрана УЗИ мочевого пузыря самки морской свинки, возраст 4 года. Хорошо визуализируется округлый уролит, дающий четкую аккустическую тень. 
Остановимся подробнее на ультразвуковой диагностике, как на одном из первостепенных и важнейших инструментальных методов диагностики уролитиаза. В настоящее время в подавляющем большинстве ветеринарных клиник, даже самых небольших, имеется в распоряжении ультрасонографическая техника, что позволяет включать этот метод исследования в обязательный алгоритм обследования животных с урологическим синдромом.

Для уролитов характерна повышеная эхогенность. По характеру изображениямы можем судить о размере уролитов, плотности их структуры, размере, локализации, подвижности, а также судить о тех изменениях, которые может вызывать присутствие уролитов в органах мочеиспускания. Например, наличие уролита в мочеточнике может вызвать полную его обструкцию и последующее расширение краниального участка мочеточника, расширение лоханки почки, а в дальнейшем - гидронефроз.

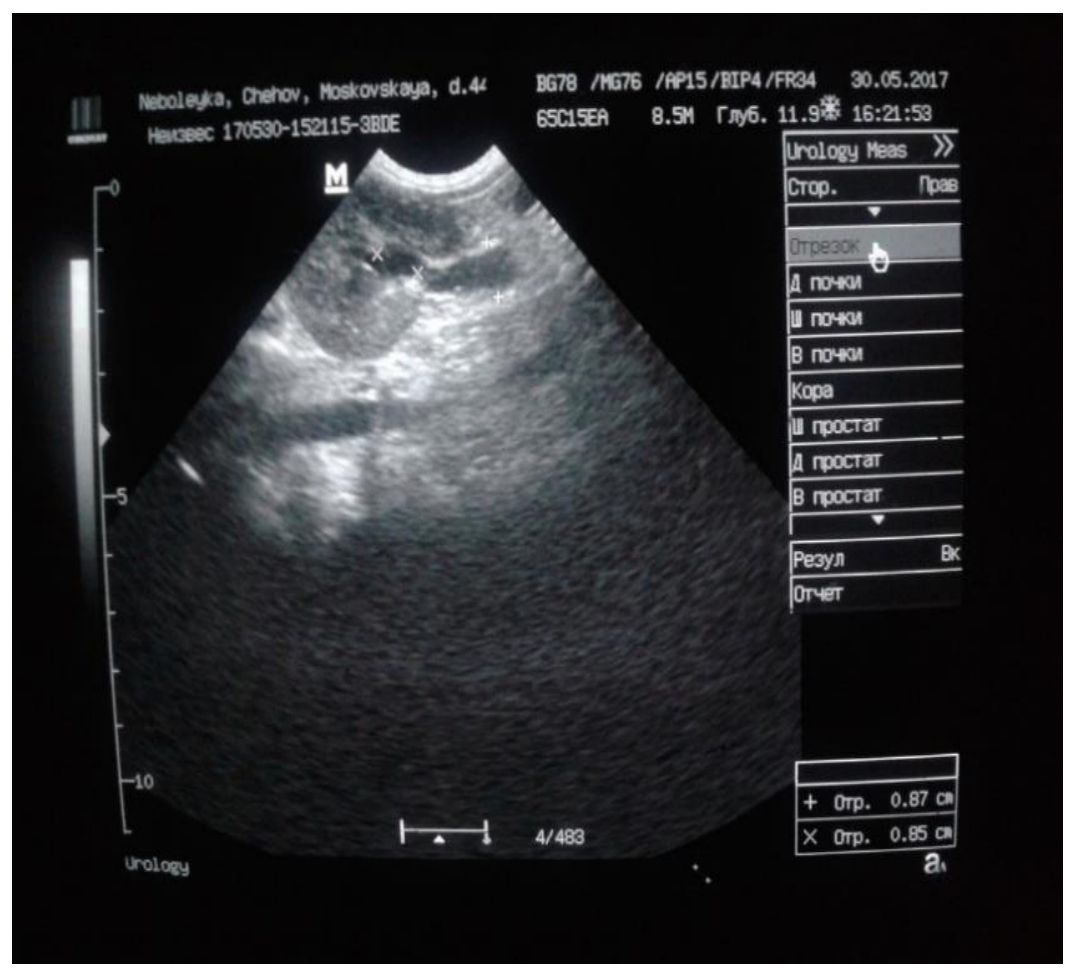

Рисунок 4. Фото с экрана ультрасонографического исследования почки собаки породы чихуахуа. 9 лет. Расширение мочеточника

На рис.4. представлено сонографическое исследование почки собаки (породы чихуахуа), 9 лет, с обструкцией мочеточника. Хорошо визуализируется расширенный мочеточник (в норме он не визуализируется) и начальное расширение лоханки почки. Невозможность дальнейшего отхождения мочи приводит к обратному забросу мочи в почку, гибели паренхимы почки, гидронефрозу, дальнейшей атрофии почки, разрыву мочеточника, мочевому перитониту. Своевременная ультрозвуковая диагностика данной патологии очень важна, позволяет вовремя устранить обструкцию и минимализировать возможные последствия. Длительно протекающий гидронефроз приводит к необратимым изменениям в паренхиме почки, полной потере правильной эхографической структуры. По выявленным ультразвуковым изменениям в структуре почки можно косвенно судить о длительности процесса и прогнозе заболевания.

На рис.5 представлена почка кота на терминальной стадии гидронефроза: хорошо видна полная потеря нормальной эхографической структуры почки, значительные анэхогенные полости с эхоусилением под ними, подтверждающим жидкостное содержимое полостей и гиперэхогенный нефролит, дающий четкую аккустическую тень, видимо и послужившийпричиной обструкции выхода из лоханки почки в мочеточник. 


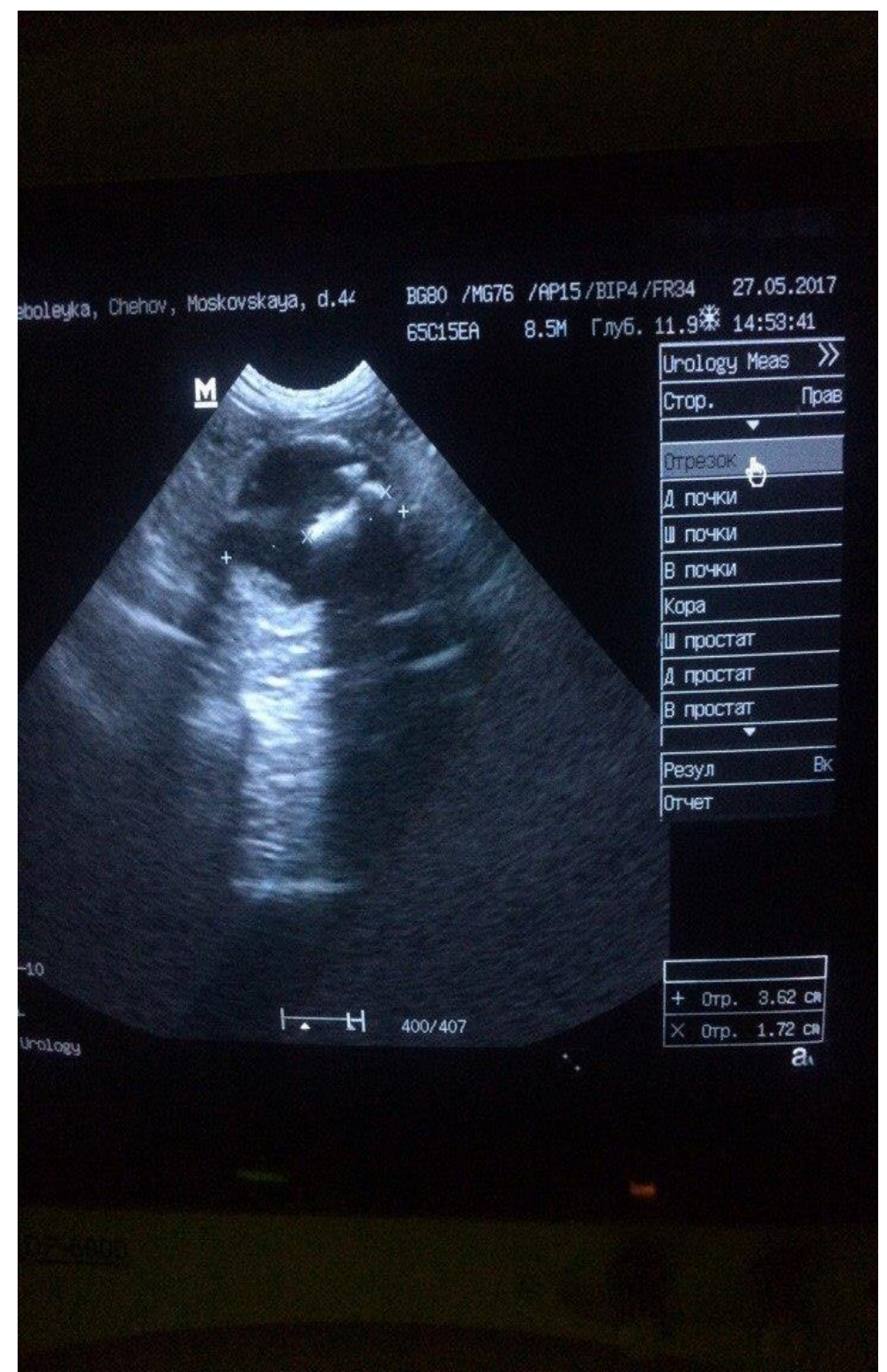

Рисунок 5. Фото с экрана ультрасонографического исследования почки кота с ХБП и гематурией

Расширенные мочеточники хорошо визуализируются и, в процессе исследования возможно проследить их протяженность вплоть до нахождения конкремента, вызвавшего обструкцию.

Уролиты в просвете мочевого пузыря могут визуализироваться в виде мелкодисперсной осаждаемой эхогенной взвеси. Мелкие крупинки, взвешенные в просвете пузыря так же дают тени, но на фоне анэхогенной мочи короткие аккустические тени могут быть не видны, не выступать за контур пузыря. Более крупные уролиты хорошо визуализируются, дают четкие аккустические тени, обычно округлой формы. Плотные по структуре конкременты визуализируются в виде ярких тонких гиперэхогенных дугообразных структур (чешуек), что связано с плохим звукопоглощением и четким отражением ультразвука от плотной звукоотражающей поверхности. Рыхлые по структуре конкременты обладают более проницаемой для ультразвука структурой и визуализируются в виде овальных или округлых гиперэхогенных структур, дающих четкие аккустические тени. Встречаются уролиты различных форм, дающие при исследовании достаточно необычные картины. 


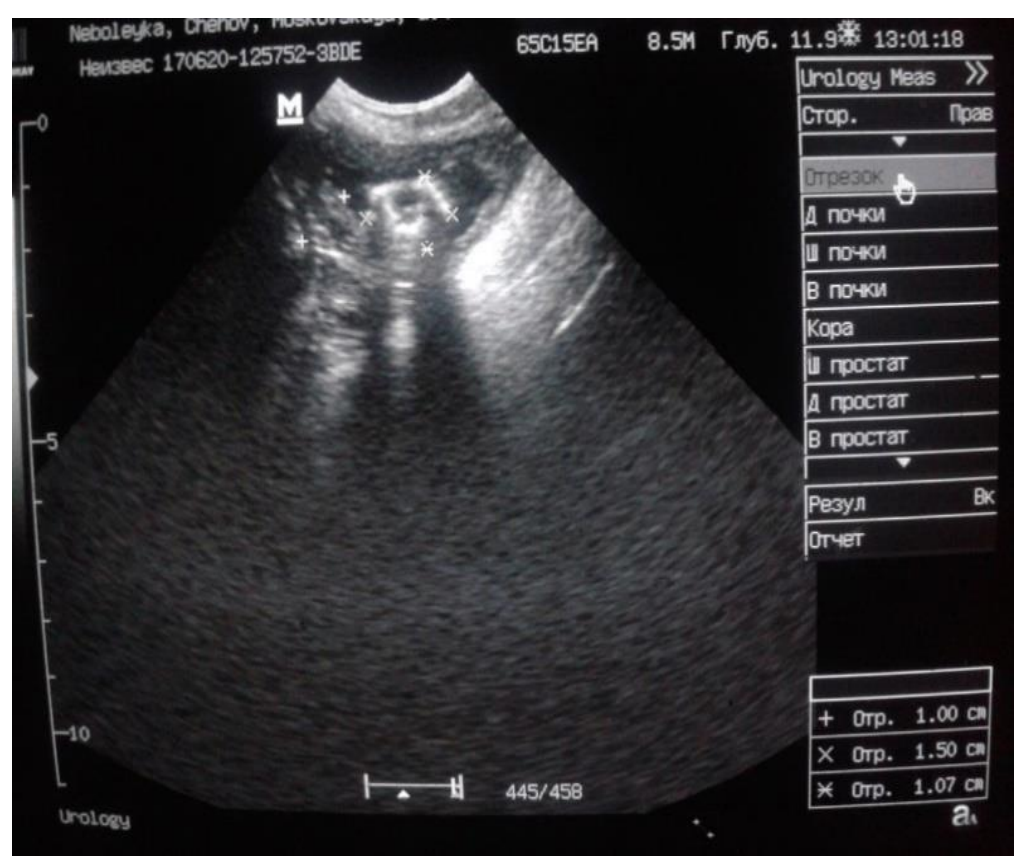

Рисунок 6. Фото с экрана ультрасонографического исследования мочевого пузыря собаки породы йоркиирский терьер

На рис 6 представлена визуализация в просвете мочевого пузыря гиперэхогенной многоугольной структуры, дающей четкие аккустические тени, которые подтверждают наличие в мочевом пузыре уролита. В последствии при цистотомии был извлечен уролит необычной перстневидной формы (рис. 7). Что и объяснило наличие двойной аккустической тени и изломанные гиперэхогенные очертания (звук не отражался, проходил насквозь в отверстие конкремента). Так же по ультразвуковой картинке можно видеть утолщение стенок мочевого пузыря, вызванное воспалением, спровоцированном наличием крупного конкремента.

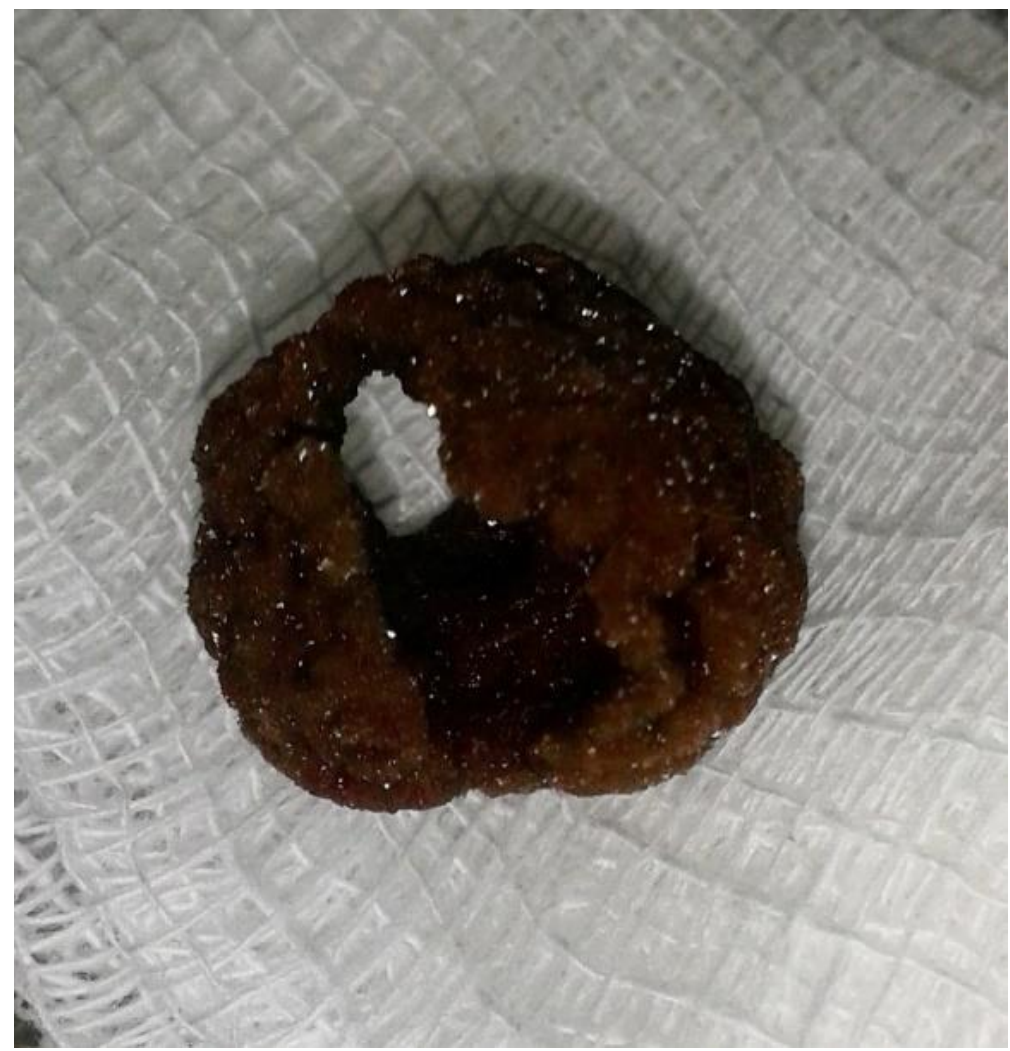

Рисунок 7. Перстневидный уролит, извлеченный из мочевого пузыря собаки, породь йоркиирский терьер 


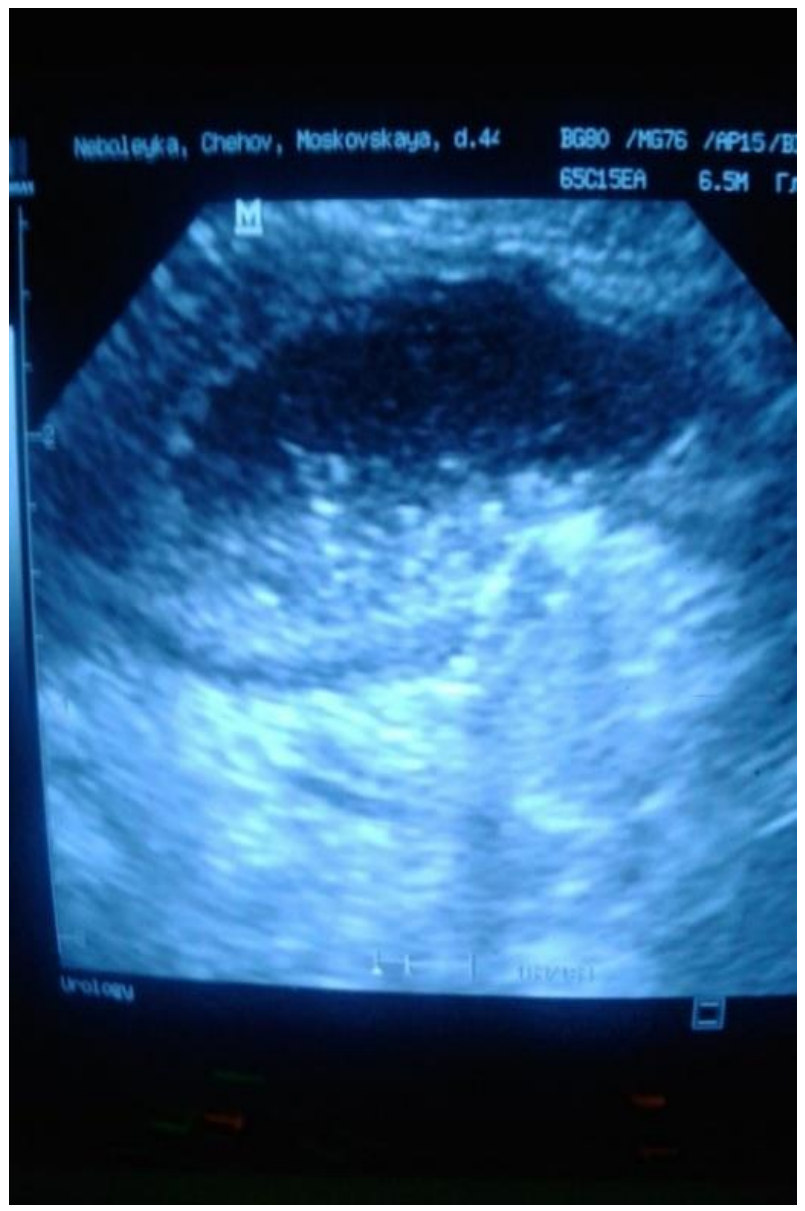

Рисунок 8

На рис.8 представлен снимок с экрана УЗИ мочевого пузыря кошки со значительно утолщенными, в следствие воспаления, стенками, наличием слизи, двух гиперэхогенных достаточно крупных, рыхлых по структуре конкрементов, дающих длинные четкие аккустические тени а так же со взвесью мелких конкрементов с короткими , не визуализирующимися тенями. В момент исследования взвесь, поднятая компрессионным воздействием датчика, осаждалась.

При проведении УЗИ мочевого пузыря так же могут визуализироваться гиперэхогенные участки стенки, испускающие аккустическую тень, не разбиваемую и не поднимающуюся турбулентными потоками в полость пузыря в виде осаждаемой взвеси при компрессионном воздействии датчиком. Такие участки представляют из себя скопления пескообразных солей и мелких уролитов, внедрившиеся в рыхлую воспаленную слизистую стенки мочевого пузыря и удерживаемые отекшей слизистой оболочкой в ее толще. В данном случае в пробе мочи, полученной для анализа соли могут не определиться, (так же бывает при наличии одиночного крупного уролита) что даст ложно отрицательный лабораторный результат на наличие кристаллурии. Поэтому даже при отсутствии в анализе мочи кристаллов солей ультразвуковая диагностика мочевых путей животных с нарушениями мочеиспускания строго необходима, дабы избежать ошибок в диагностике .

Рентгеновское исследование брюшной полости животных с проблемами мочеиспускания так же очень важна и входит в алгоритм обязательного исследования при гематурии и дизурии. [...] УЗИ и рентген взаимно дополняют друг друга. При поступлении на прием животных с нарушениями мочеиспускания необходимо настоятельно разъяснять владельцам необходимость в проведении комплексной диагностики ради исключения диагностических ошибок и возможного недодиагностирования. 


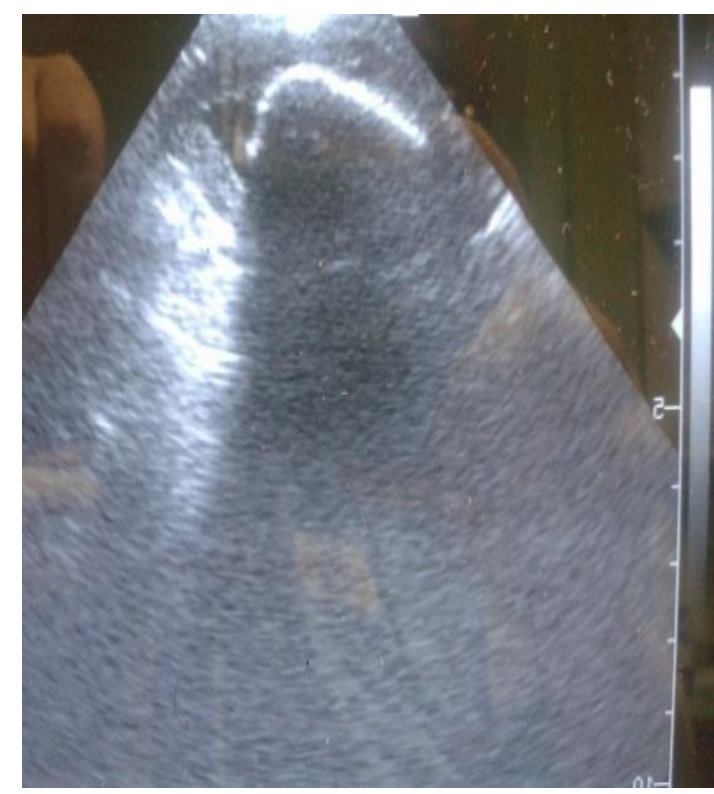

Рисунок 9

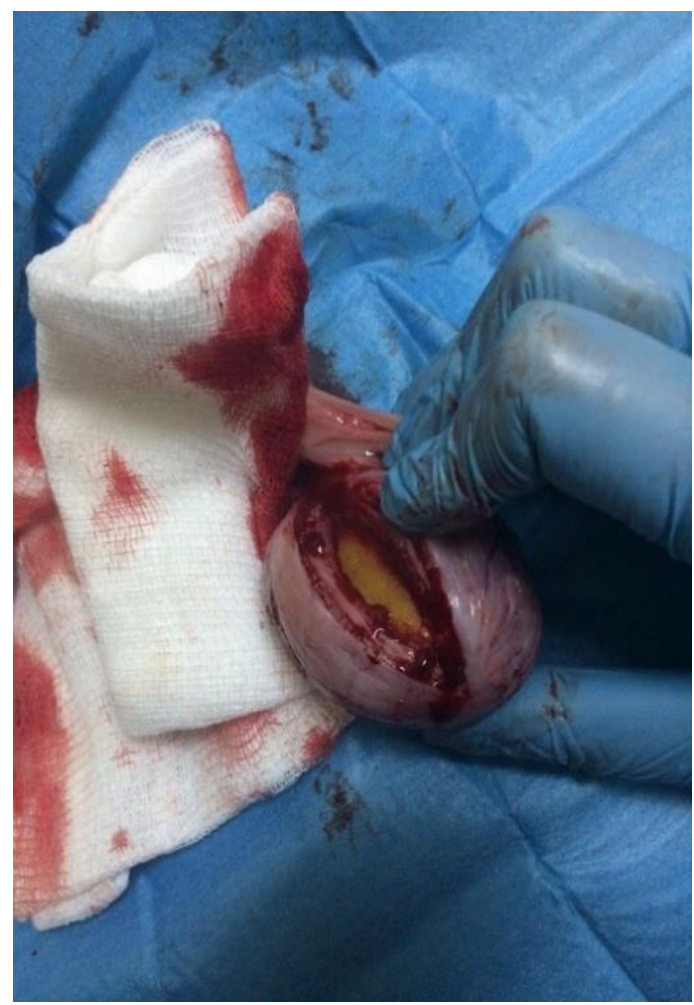

Рисунок 11

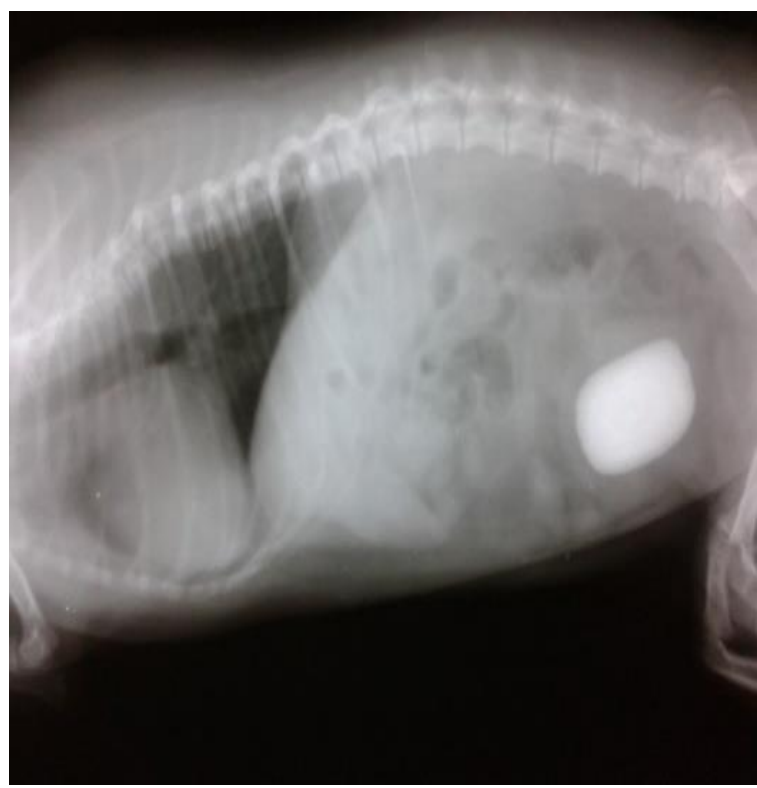

Рисунок 10

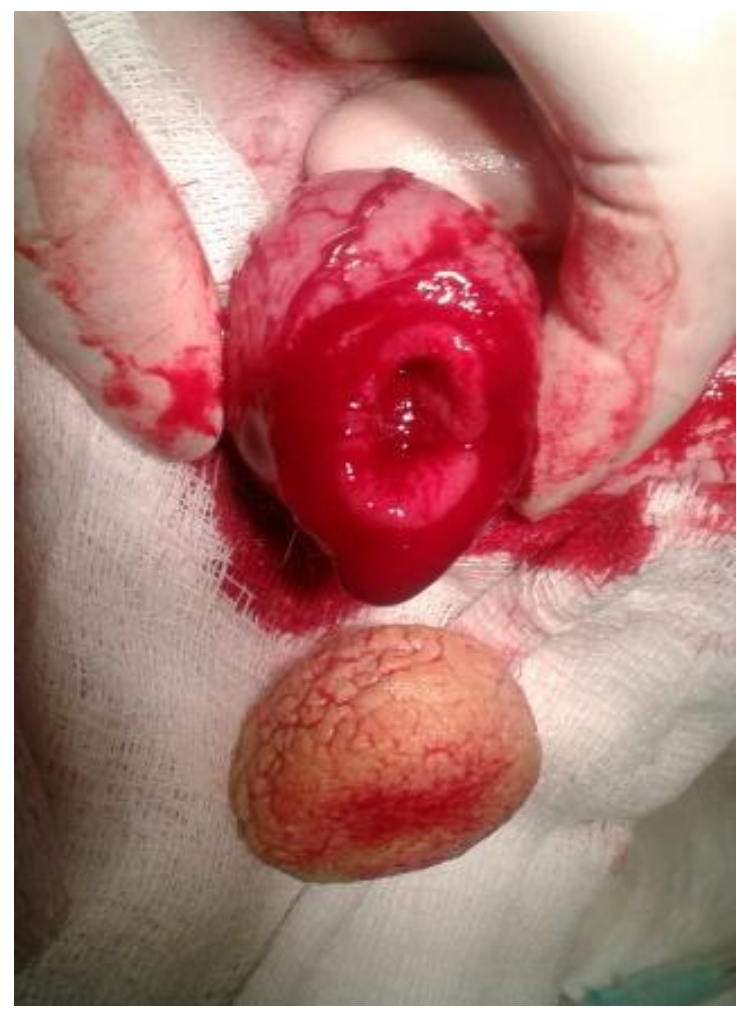

Рисунок 12

На выше представленных рис.9,10,11,12 отражены как этапы диагностики уролитиаза у собаки - УЗИ и рентгеновский снимок, так и дальнейшую цистотомию с целью удаления крупного конкремента из мочевого пузыря. На фото хорошо видно насколько утолщены и воспалены стенки мочевого пузыря.

На ниже представленных фото :

Рис.13: рентгеновский снимок брюшной полости собаки, породы тибетский мастиф с дизурией и гематурией ,с выявленным скоплением уролитов в мочевом пузыре. На фото 14.- удаленные , в ходе цистотомии, уролиты в достаточно большом количестве, конкременты заполняли практически всю полость мочевого пузыря, вызывая раздражение его стенок, воспаление и активную гематурию (согласно далее проведенному лабораторному исследованию - струвиты). 


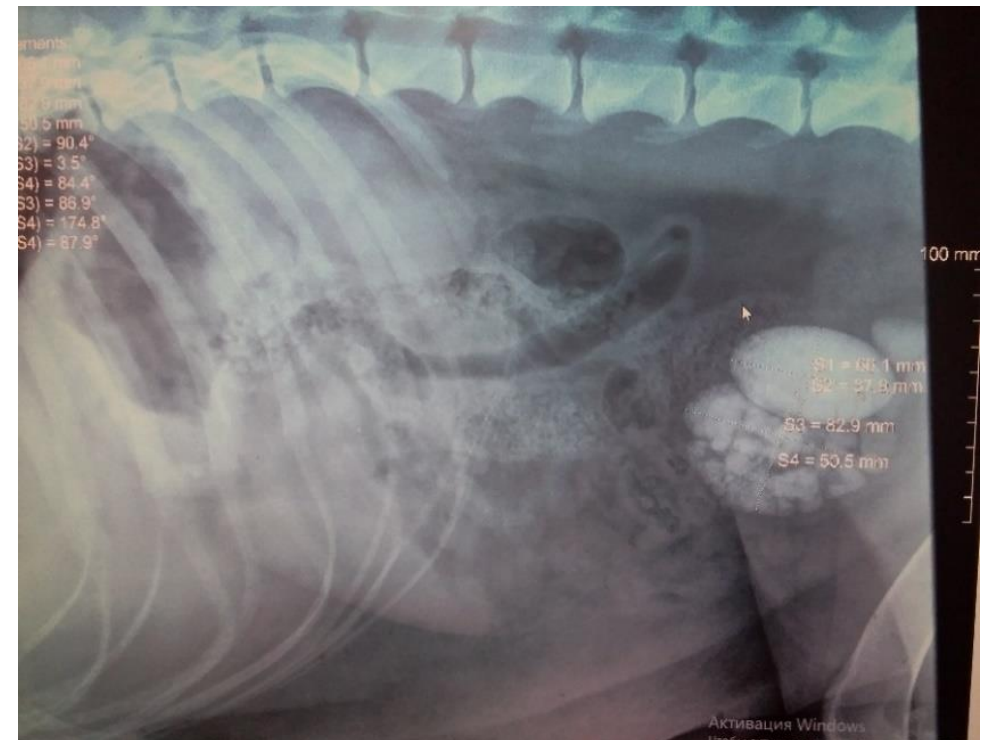

Рисунок 13

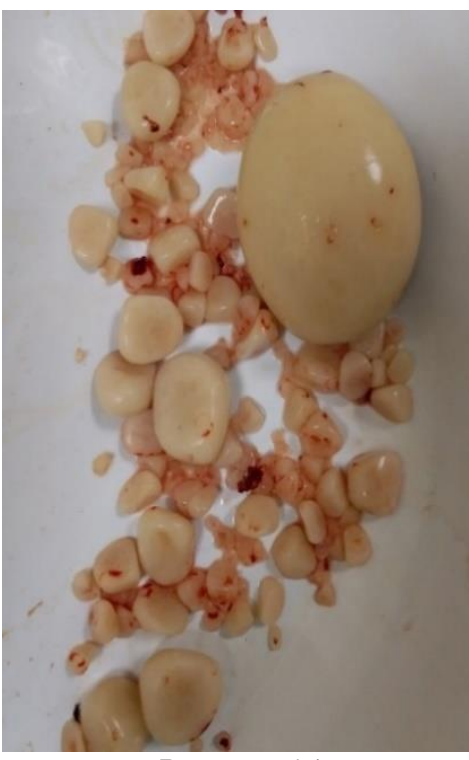

Рисунок 14

Иногда при проведении УЗИ наличие мелких нефролитов почках сомнительно, так как серошкальное изображение достаточно условно. И при сомнениях, рентгеновское исследование помогает подтвердить или исключить минерализацию паренхимы почек. На рис.15 представлен рентгеновский снимок брюшной полости собаки породы чихуахуа, возраст 7 лет, страдающей странгурией и гематурией. При проведении УЗИ визуализация уролитов в мочевом пузыре была достоверной, а минерализация пренхимы почек была достаточно сомнительной. Рентген подтвердил нефролитиаз. На рис.16 -уролиты, удаленные у данной собаки при уретротомии.

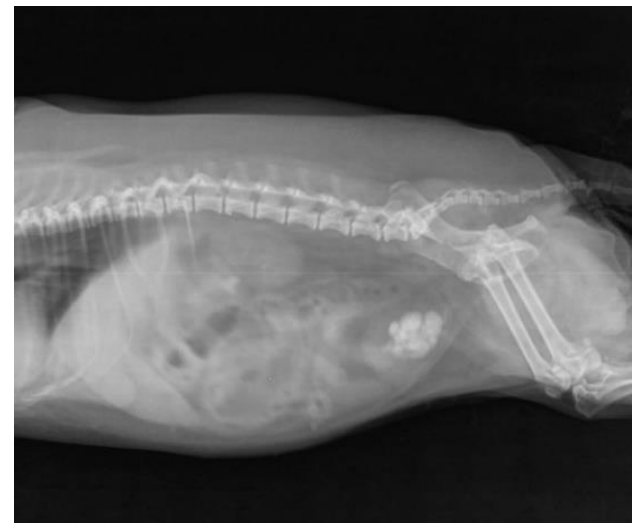

Рисунок 15

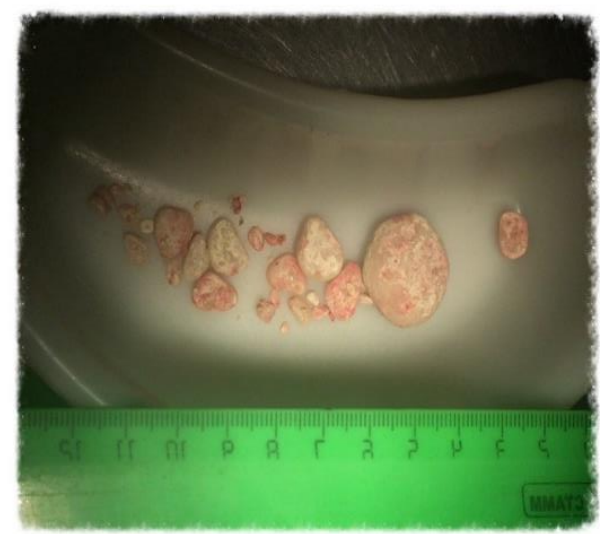

Рисунок 16 


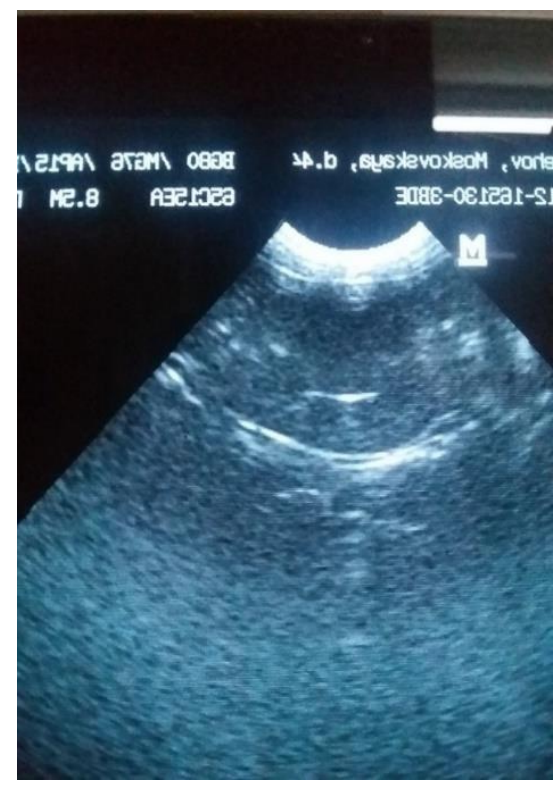

Рисунок 17

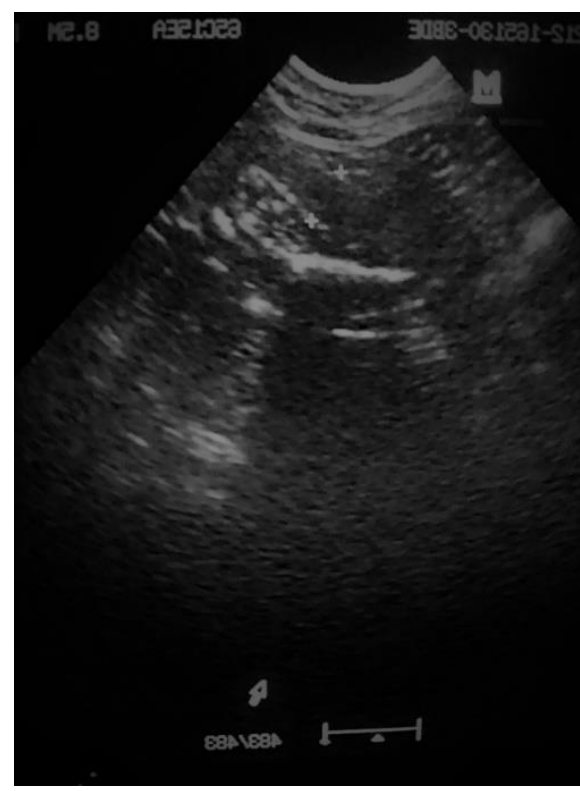

Рисунок 18

На рис.17 представлен снимок с экрана УЗИ 4х-летнего кота британской породы, с признаками острой обструкции мочевого пузыря, внезапно развившейся , по словам владельцев, в течение суток. На снимке - почка кота, с признаками минерализации лоханки (гиперэхогенная яркая полоска на дне лоханки. А на рис.18 представлен снимок УЗИ мочевого пузыря данного кота, сделанный после отведения основной массы мочи. Хорошо визуализируется гиперэхогенный осадок, дающий аккустическую тень и утолщение стенок мочевого пузыря в связи с острым их воспалением (указано крестиками).

При микроскопии капли мочи, отведенной из мочевого пузыря у данного кота выявлено наличие множественных эритроцитов в моче и наличие кристаллов струвитов и оксалатов (фото микроскопического исследования капли мочи данного животного представлено на рис.19).

По экспресс-анализу мочи (анализ был проведен при помощи аппарата для экспресс-диагностики мочи ДокУридер) кислотность (Рн) мочи у кота составила 9 (норма Рн 6-6,5) , что и обусловило образование массы кристаллов триппель-фосфатов (струвитов). Оксалаты в данной пробе мочи встречались единичными.

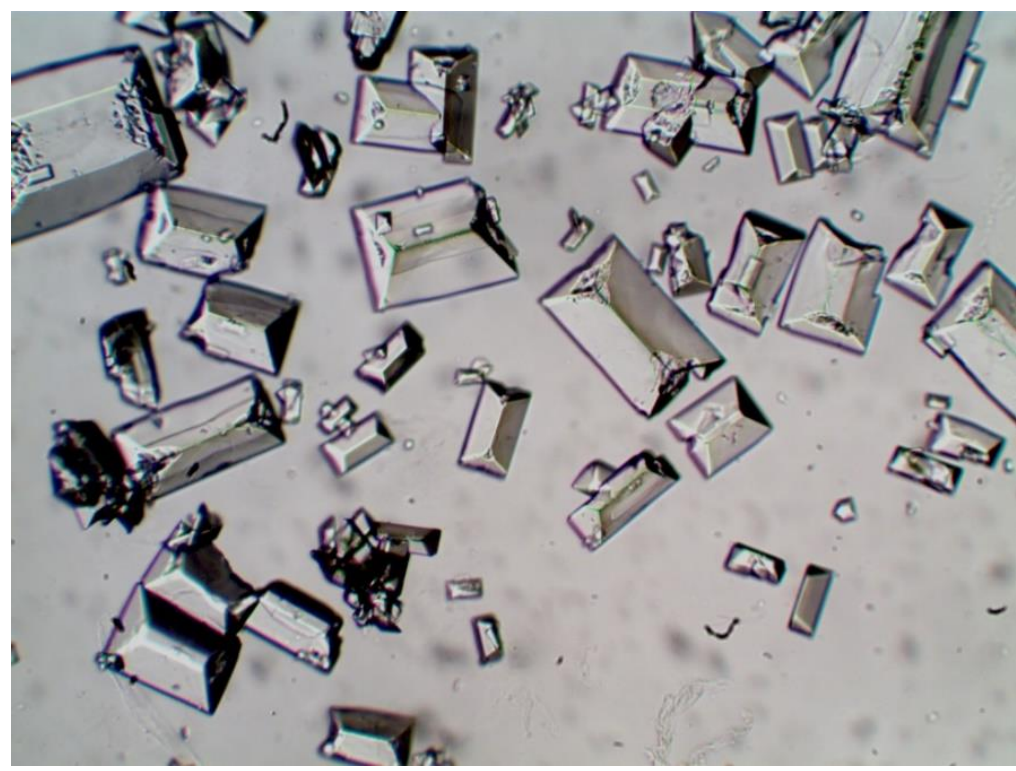

Рисунок 19. Фото зрительного поля микроскопа при микроскопии капли мочи кота, британской породь, возраст 4 года 
Чувствительность и достоверность методов ультрасонографии и рентгенографии в случае диагностики уролитиаза достаточно высока, оба этих методов имеют свои ограничения , но хорошо взаимодополняют друг друга [...].

Таблииа 2

\begin{tabular}{|c|c|c|}
\hline УЗИ & Высокая чувствительность & Средняя спечифичность \\
\hline РЕНТГЕН & Средняя чувствительность & Высокая спеиифичность \\
\hline
\end{tabular}

В заключении необходимо еще раз отметить важность своевременной диагностики уролитиаза, т.к. длительная обструкция конкрементами уретры приводит к тяжелейшим последствиям. Для иллюстрации приведу фото монитора во время проведения цистоэндоскопии мочевого пузыря кота после трехдневной острой обструкции уретры. На рис.3 представлена эндоскопическая картина повреждения слизистой мочевого пузыря кота в результате трехдневной острой обструкции уретры у кота при проведении интраоперационной цистоэндоскопии . Хорошо видны некротизированные участки слизистой оболочки мочевого пузыря, возникшие при развившейся ишемии перерастянутых стенок мочевого пузыря.

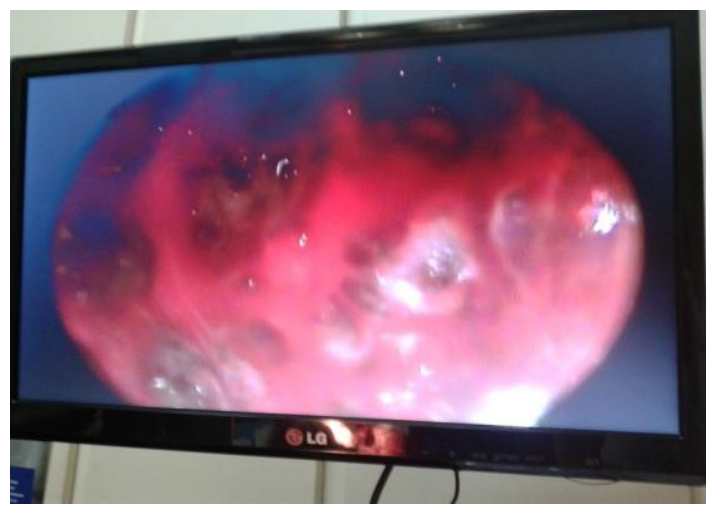

Рисунок 20. Фото монитора при проведении эндоцистоскопии мочевого пузыря кота после трехдневной обструкции уретры мочевыми конкрементами

Заключение. В целом, выводы из проведенного исследования можно сформулировать следующим образом: в случае поступления на прием к ветеринарному врачу животного с признаками нарушения мочеиспускания (странгурия, гематурия, анурия, олигоурия, поллакиурия, периурия) , строго необходимыми этапами диагностики, (после сбора анамнеза , физикального осмотра, стандартных анализов: взятия проб крови и мочи на общий и биохимический анализы), являются методы , которыми ни в коем случае нельзя пренебрегать и выполнять в обязательном порядке: ультрасонография (УЗИ) и рентген-диагностика.

$$
* * *
$$

1. ЖурналVeterinaryFocus, издательствоBuenaMediaPlus, $\quad$ France $\quad$ - 2007 г.РедакторDr.RichardHarvey,PhD, BVSc, DVD

2. Нефрология и урология собак и кошек, первое издание, (под редакцией Джона Байнбриджа и Джонатана Эллиота,/пер. с английского Е.Махиянова - Москва, ООО «Аквариум-Принт», 2008.272 с.: илл. ISBN 978-5-9934-0046-4

3. Иванов В.В. Клиническое ультразвуковое исследование органов брюшной и грудной полости у собак и кошек. Атлас - Москва, ООО «Аквариум-Принт», 2007.- 176 с.:ил.ISBN 978-5-98435-820-0

4. УЗИ в ветеринарии. Дифференциальная диагностика болезней мелких домашних животных. Практическое руководство с графическими схемами и сонограммами/ Е.В.Бушарова; подред.канд.биол.наук Чуваева И.В. - СПб: Институт Ветеринарной Биологии, 2011. - 276 с.силл. ISBN 978-5-9902656-1-5 (НОУ ДО «Институт Ветеринарной Биологии)

5. Ультразвуковая диагностика заболеваний мелких домашних животных (под общей редакцией Пэдди Манниона)/ Пер. с англ. - М.: «Аквариум-Принт, 2008. - 320 с.: ил.ISBN 978-5-9934-0053-2

6. Нефрология и урология собак и кошек. 2-е издание - под редакцией Дж.ЭллиотаиГ.Гроера/ Пер. с англ. - М.:АквариумПринт, 2014. - 352 с.: ил. + 24 с.цв.вкл. ISBN 978-5-4238-0275-2 


\title{
SECTION V. CONSTRUCTION
}

\author{
Панченко Н.М. \\ О необходимости учёта влияния параметров надёжности строительной системы \\ на её производительность (на примере процесса производства земляных работ \\ экскаваторным комплектом) \\ Петербургский государственный университет путей сообщения Императора \\ Александра I \\ (Россия, Санкт-Петербург)
}

doi 10.18411/gq-15-10-2021-11

\section{Аннотация}

В последние десятилетия в области строительства активно внедряются средства механизации и автоматизации, но благодаря этому не всегда удаётся повысить эффективность строительного производства. Каждый комплексный строительный процесс сложен, элементы, из которых он состоит, имеют строго определённую соподчинённость и последовательность. Изменение производительности в одном из составляющих процесса приводит обычно к изменению производительности всего комплексного процесса в целом. Отсутствие необходимых методологических разработок не позволяет достоверно оценивать фактическое состояние интенсификации используемых процессов. Данная статья освещает вопросы разработки методологии выявления и учёта влияния технологических, человеческих и технических параметров надёжности на производительность строительных систем.

Ключевые слова: надёжность, большая система, элемент системы, вероятность безотказной работы, технология, строительный процесс, параметры надёжности.

\section{Abstract}

In recent decades, means of mechanization and automation are actively implementing in building, but it is not always possible to increase the efficiency of construction production. Each complex construction process is complicated; the elements of which it consists have a strictly defined subordination and sequence. A change in productivity in one of the components of the process usually leads to a change in the performance of the entire complex process as a whole. The lack of the necessary methodological developments does not allow to reliably assessing the actual state of intensification of the processes used. This article highlights the development of a methodology for identifying and accounting for the impact of technological, human and technical parameters of reliability on the performance of building systems.

Keywords: reliability, large system, system element, probability of failure-free operation, technology, construction process, reliability parameters.

\section{1. Введение.}

Сфера строительства занимает особое место в системе функционирования любой развитой страны мира. Решению задач в области выбора рациональных путей интенсификации строительных процессов посвящено множество работ российских учёных, начиная с 60-х годов прошлого века, с периода наращивания в нашей стране темпов комплексной механизации, таких как С.С. Атаев, В.И. Рыбальский, Б.В. Прыкин и другие. И хотя за последние десятилетия было создано немало разработок и выдвинуто множество современных идей, ясности в выборе рациональных путей интенсификации строительных процессов не появилось. Внедрение средств автоматизации и робототехники, как показывает практика, не всегда способно повысить эффективность строительного производства. А совершенствование 
строительных технологий часто происходит без учёта системности строительных процессов.

Как известно, каждый строительный процесс обладает таким свойством, как индивидуальность [7]. Изменение производительности в одном из составляющих процесса приводит обычно к изменению производительности всего комплексного процесса в целом. Это доказывает сложность и многообразие самих комплексных процессов и многофакторность воздействия на них различных условий. Вместе с этим, отсутствие необходимых методологических разработок не позволяет достоверно в необходимой степени оценивать фактическое состояние интенсификации используемых процессов, определить наиболее рациональные пути реализации возможностей для выбранной технологии, а также обосновать наиболее эффективные границы её использования и совершенствования. Как последствие мы можем наблюдать отклонения фактических сроков строительства от проектных и ненадлежащий уровень качества строительной продукции. Для того чтобы минимизировать данные последствия, необходимо триединое изучение влияния выбираемой технологии, людей и состояния применяемой техники на производительность строительных процессов и разработка методологии выявления и учёта данного влияния.

\section{2. Материалы и методы.}

Комплексные строительные процессы, это процессы особого рода, обладающие определёнными свойствами и имеющие ряд особенностей. Итогом каждого строительного процесса является доброкачественная строительная продукция. Но качество произведённой продукции не всегда гарантировано качеством проведения производственного процесса, так как у некоторых процессов время производства работ и физико-химических изменений в строительных материалах может иметь разные интервалы.

Ещё одна особенность строительных процессов заключается в том, что не каждая продукция строительного производства может быть зарезервирована, а сам процесс должен функционировать без простоев. Поэтому строительные процессы должны обладать необходимой и достаточной надёжностью, чтобы исключить возможность получения брака. Комплексно механизированные процессы, как правило, имеют низкую надёжность из-за преобладания в организации их функционирования последовательных или последовательно-параллельных технологических операций. Существующая нормативная документация не учитывает надёжность процессов ни на стадии их проектирования, ни на стадии строительства. Надёжность рабочих вообще не участвует в расчётах, надёжность техники учитывается коэффициентом использования машины по времени при расчёте производительности машины, что явно недостаточно для получения достоверных результатов при определении производительности строительного процесса и сроков строительства.

Инструментом для исследования вопросов надёжности строительных процессов является математическая теория надёжности. Надёжность любой системы определяется способностью сохранять заданные рабочие параметры в течении определённого расчётного срока. Это высказывание справедливо и для исследования строительных систем. За последние десятилетия за счёт технического прогресса, процессы проектирования и строительства промышленных и гражданских объектов перешли в разряд больших сложных систем, состоящих из множества подсистем, складывающихся из огромного количества элементов, носящих вероятностный характер и подчиняющихся законам теории вероятности. Благодаря этому, принятие организационных, технологических и экономических решений стало более сложным, как результат, получаем снижение надёжности систем строительного производства в целом. Следовательно, наблюдаем ухудшение фактических показателей (увеличение 
сроков продолжительности строительства, снижение производительности труда, изменение стоимости строительства) по сравнению с запланированными.

Сложность решения проблемы надёжности в области строительства заключается в том, что математический аппарат теории надёжности, применяемый для технических систем, недостаточен для строительных систем, так как не учитывает экономических, организационных и технологических нюансов, определяющих причины отказов и надёжность строительных систем, а главное не учитывает роли человека в производственном процессе. Данный математический аппарат рассчитан на системы со стационарными режимами функционирования, строительные системы - это системы с динамическим режимом [5]. Для технических систем выход из строя какого-либо элемента или узла часто ведёт к полному отказу системы, а для строительных "характерными являются не полные отказы, а частные (сбои), которые самоустраняются в процессе непрерывного функционирования системы" [1]. Согласно математической теории надёжности, системы, состоящие из множества последовательно соединённых элементов, при увеличении в своём составе таких элементов резко снижают свою надёжность. И даже сравнительно небольшие системы, которые состоят из небольшого количества элементов с достаточно высокой средней надёжностью каждого элемента, будут на выходе иметь довольно низкую надёжность [2]. Исследуя строительные системы и сравнивая их с техническими, приходим к выводу, что даже при одинаковом количестве элементов и более низкой надёжности каждого из них, строительная система будет иметь более высокую надёжность в итоге, чем техническая. Это доказывает то, что строительные системы более гибкие, чем технические, легче резервируются и способны быстро перестраиваться. В технической системе надёжность напрямую зависит от надёжности составляющих её элементов, а в строительной от её гибкости. Это объясняется наличием в строительных системах "самого надёжного саморегулируемого" элемента системы - человека [1].

\section{3. Результаты и обсуждения.}

Надёжность участия человека в производственном процессе можно охарактеризовать, используя следующие понятия, применяемые в математической теории надёжности: вероятность безотказной работы, вероятность отказов, интенсивность отказов, интенсивность восстановлений, хотя и нельзя полностью перенести хорошо разработанные в теории надёжности понятия для техники на человека. Человек - это особый элемент строительной системы, которому присущи особые свойства. Под отказом человека будем понимать неспособность выполнения им заданных функций с требуемой точностью в определённый промежуток времени. Отказы человека в производственной системе могут быть временными или постоянными. Временные - это такие, которые не связаны с какими-либо изменениями в организме человека и могут быть устранены при повторном действии, например, ошибка в работе оператора. Постоянные связаны с изменениями в организме человека, например, болезнь. Каждый из элементов строительной системы (рабочие и техника) индивидуален, их отказы и восстановления по количеству и продолжительности не зависят от других элементов. Следовательно, вероятность безотказной работы строительной системы $\mathrm{P}(\mathrm{t})$ может быть выражена множеством:

$$
\left\{\prod_{i=1}^{n} P_{i}(t) \times \prod_{j=1}^{m} P_{j}(t)\right\}
$$

где:

$P_{i}(\mathrm{t})$ - вероятность безотказной работы і-го рабочего системы;

$P_{j}(\mathrm{t})$ - вероятность безотказной работы ј-ой машины или механизма системы.

Любой строительный процесс - это человеко-технологическая система, где рабочие и техника соединены определённым образом и, используя наиболее рациональную технологию, производят конечную продукцию. Одним из наиважнейших критериев в выборе количества и типов машин и числа и квалификации 
рабочих, участвующих в строительном процессе, является технология производства работ [3]. Поэтому исследование любого строительного процесса с точки зрения большой системы необходимо одновременно относительно трёх факторов: технологического, человеческого и технического.

Каждый строительный процесс функционирует с определённой производительностью, которая обеспечивается необходимой надёжностью выполнения операций. Параметры надёжности заложены в структуре технологических операций, они могут быть описаны множеством:

$$
\begin{aligned}
& \text { — } \quad \text { человеческие: }\left\{x_{i}\right\}(i=\overline{1, n}), \\
& \text { - технические: }\left\{y_{j}\right\}(j=\overline{1, m}), \\
& \text { — } \quad \text { технологические: }\left\{z_{l}\right\}(l=\overline{1, k}) .
\end{aligned}
$$

Технологические параметры надёжности являются основными, от них зависит количество рабочих, их квалификация, выбор машин и механизмов.

Исследуя процесс производства земляных работ с использованием экскаваторного комплекта техники в качестве примера, представим данный строительный процесс в виде большой системы. В процессе производства рабочие при помощи орудий труда преобразуют предмет труда из исходного состояния в готовую продукцию (земляное полотно). Преобразование предмета труда из одного состояния в другое происходит в соответствеии с применяемой технологией на каждой из операций поэтапно [4]. Например, какая-то одна из систем большой системы C имеет n-oе количество операций, тогда степень преобразования предмета труда в этой системе может быть выражена следующей функцией:

$$
\Pi: C_{1} \rightarrow C_{n}=\Pi_{l} \cup \Pi_{2} \cup \ldots \cup \Pi_{n}=\bigcup_{l=1}^{n} \Pi_{l}, l=\overline{1, n}
$$

Технологические операции состоят из конечного числа технологических действий. Степень преобразования предмета труда в пределах одной операции может быть представлена функцией:

$$
\Pi_{l}=P_{l} \cup P_{2} \cup \ldots \cup P_{l}=\bigcup_{j=1}^{k} P_{j}, j=\overline{1, k}
$$

Поддержание строительного процесса по производству земляных работ на уровне стабильного функционирования должно происходить за счёт поддержания параметров надёжности самого строительного процесса, как большой системы, параметров надёжности технологических операций, как подсистем и на уровне составляющих каждой подсистемы, её элементов: рабочих и техники [6]. Следовательно, стабильно функционирующая строительная система должна иметь надёжность:

$$
\begin{array}{r}
\text { на уровне і-го производственного процесса: } \\
P_{i}(t)=\left\{P_{i}(t)\right\}(i=\overline{1, n}), \\
\text { на уровне 1-й операции }(\mathrm{OП}): \\
P_{l}(t)=\left\{P_{l}(t)\right\}(l=\overline{1, m}), \\
\text { — } \quad \text { на уровне ј-го действия: } \\
P_{j}(t)=\left\{P_{j}(t)\right\}(j=\overline{1, k}) .
\end{array}
$$

Так как 1-я операция состоит из $\mathrm{k}$ элементов, а i-й процесс из $\mathrm{m}$ операций, то вероятность безотказной работы строительного процесса, как системы, может быть описана следующим математическим выражением:

$$
P_{i}(t)=\prod_{l=1}^{m} P_{l}(t) \prod_{j=1}^{k} P_{j}(t)
$$

Формализованную модель любого технологического процесса можно представить в виде математического соотношения множеств:

где:

$$
\begin{array}{r}
T \Pi=\Pi: C_{l} \rightarrow C_{n},\left\{x_{\mathrm{c}}\right\},\left\{y_{c}\right\},\left\{z_{c}\right\} \\
O \Pi=P: j \rightarrow k,\left\{x_{j}\right\},\left\{y_{j}\right\},\left\{z_{j}\right\}
\end{array}
$$

ТП - технологический процесс;

ОП - операция в технологическом процессе. 
Учитывая свойство соподчинённости больших систем, структурно-целевую функцию поддержания рабочего состояния строительного процесса можно выразить в следующем виде:

$$
\begin{aligned}
& \bigcup_{i=1}^{n}\left\{\Pi P_{i}(t)\right\} \\
& \bigcup_{j=1}^{k}\left\{\Pi P_{j}(t)\right\}
\end{aligned}
$$$$
\int \bigcup_{l=1}^{m}\left\{\Pi P_{l}(t)\right\} \rightarrow \text { max }
$$

Сущность полученного математического выражения заключается в том, что поддержание функционального постоянства большой системы полностью зависит от обеспечения максимальной вероятности безотказного выполнения операций производственных процессов. В полученной структурно-целевой функции $P_{i}(t), P_{j}(t), P_{l}(t)$ - вероятности безотказной работы человеко-технической системы на первичных уровнях данного процесса.

При помощи системно-структурного анализа технологий производства земляных работ, используя теоретико-множительные понятия теории систем, любой из технологических процессов возможно представить в виде математической модели, состоящей из множества операций, надёжность выполнения которых зависит от большого числа технологических, человеческих и технических параметров [8]. Для того чтобы выбрать оптимальные параметры надёжности на уровне производственных процессов, операций, действий, следует рассмотреть множество параметров ограничений на уровне процессов: $\left\{\bar{x}_{l}\right\},\left\{\bar{y}_{l}\right\},\left\{\bar{z}_{l}\right\}$, на уровне технологических операций: $\left\{\bar{x}_{J}\right\},\left\{\bar{y}_{J}\right\},\left\{\bar{z}_{J}\right\}$, на уровне технологических действий: $\left\{\bar{x}_{l}\right\},\left\{\bar{y}_{l}\right\},\left\{\bar{z}_{l}\right\}$. Задача оптимального выбора параметров надёжности имеет решение, если удовлетворяется условие пересечения множества параметров надёжности с множеством параметровограничений:

$$
\left.\begin{array}{c}
\left\{x_{i}\right\} \cap\left\{\bar{x}_{i}\right\} \neq 0 \\
\left\{y_{i}\right\} \cap\left\{\bar{y}_{i}\right\} \neq 0 \\
\cdots \cdots \cdots \cdots \cdots \\
\left\{z_{i}\right\} \cap\left\{\bar{z}_{i}\right\} \neq 0 \\
\cdots \cdots \cdots \cdots \\
\left\{z_{j}\right\} \cap\left\{\bar{z}_{j}\right\} \neq 0
\end{array}\right\}
$$

Таким образом, структурно-математическая модель технологического процесса производства земляных работ экскаваторным комплектом будет иметь следующий вид:

$$
\begin{gathered}
A \cap\left(\left[\begin{array}{c}
B_{1} \\
\downarrow \\
B_{n}
\end{array}\right\} \cup\left\{x_{B}\right\} \cup\left\{y_{B}\right\}\right. \\
\left.\cup\left\{z_{B}\right\}\right] \cup\left[\begin{array}{c}
C_{1} \\
\downarrow \\
C_{n}
\end{array}\right\} \cup\left\{x_{C}\right\} \cup\left\{y_{C}\right\} \\
\left.\cup\left\{z_{C}\right\}\right] \bigcup\left[\left\{\begin{array}{c}
D_{1} \\
\downarrow \\
D_{n}
\end{array}\right\} \cup\left\{x_{D}\right\} \cup\left\{y_{D}\right\} \cup\left\{z_{D}\right\}\right] \bigcup\left[\left\{\begin{array}{c}
F_{1} \\
\downarrow \\
F_{n}
\end{array}\right\} \cup\left\{x_{F}\right\} \cup\left\{y_{F}\right\}\right. \\
\left.\left.\cup\left\{z_{F}\right\}\right]\right)
\end{gathered}
$$

где:

А - большая система производства земляных работ;

$\mathrm{B}, \mathrm{C}, \mathrm{D}, \mathrm{F}$ - подсистемы большой системы - операции; 
В - экскавация грунта;

C - транспортирование грунта самосвалами;

D - планирование грунта бульдозерами;

$\mathrm{F}$ - уплотнение уплотняющей техникой.

Решение структурно-формализованной функции (8) будет оптимальным при соблюдении условия (7).

\section{4. Выводы.}

Исходя из выше сказанного можно сделать следующий вывод: для того, чтобы оценить влияние параметров надёжности элементов составляющих производственный процесс на производительность данного процесса и сроки производства работ, необходимо найти фактические значения параметров надёжности элементов процесса исходя из технологии производства работ, структурных связей и расположения элементов в процессе как системе [9]. Если система функционирует без сбоев, то и производительность процесса высока, а сроки оптимальны. Если в системе происходят сбои, то в зависимости от соединения элементов в структуре процесса, от места нахождения данного элемента в данной структуре мы получим изменения в производительности и сроках производства работ. Следовательно, можно отметить, что надёжность элементов составляющих производственный процесс определённым образом влияет на функционирование строительного процесса, но в полной мере исследование данного вопроса возможно только с учётом триединого влияния технологических, человеческих и технических факторов.

$$
* * *
$$

1. Гусаков А.А. Системотехника строительства. М., Стройиздат. 1993. 440с.

2. Губинский А.И. Надёжность и качество функционирования эргатических систем. Л., Наука. 1982. 262c.

3. Неснов В.И. Бизнес и политика в теории эргатических систем. СПб. 2000. 142c.

4. Панченко Н.М. Методологические основы комплексного проектирования сложных строительных процессов (на примере производства земляных работ). Автореферат диссертации. СПб., 1999. 25 с.

5. Спиридонов Э.С., Максимов А.В. Научные основы оптимизации организации и управления комплексом работ по переустройству транспортных объектов. - М.: Известия, 1998, 290 с.

6. Панченко Н.М. К вопросу выбора комплекта строительной техники при производстве земляных работ. Вопросы образования и науки. Сборник научных трудов по материалам международной научно-практической конференции 30 июня 2020 г. Часть 1. Тамбов 2020. Стр. 85-87

7. Панченко Н.М., Басовский Д.А. Специфические особенности строительных процессов. Актуальные проблемы развития транспортной инфраструктуры. Сборник научных трудов. СанктПетербург 2018. Стр. 233-236

8. Панченко Н.М. К проблеме надёжности строительных процессов и путям её решения. Наука, образование, общество. Сборник научных трудов по материалам международной научнопрактической конференции 29 февраля 2016 г. Часть 2 Тамбов 2016. Стр. 86-88

9. Панченко Н.М. Человеко-технические системы на макро- и микроуровнях. Наука, образование, общество. Сборник научных трудов по материалам международной научно-практической конференции 30 сентября 2016 г. Часть 2 Тамбов 2016. Стр. 91-94 


\section{SECTION VI. ASTRONOMY}

\section{Плеханов П.Г. \\ Третий пояс в солнечной системе и его первые открытые объекты}

Астрономическая лаборатория СКБ ГБПОУ СМК и СУ

(Россия, Санкт-Петербург)

doi $10.18411 / g q-15-10-2021-12$

\section{Аннотация}

В строении Солнечной системы автором рассматриваются две подсистемы «группа-пояс»: подсистема «внутренняя группа планет - пояс астероидов» и подсистема «внешняя группа планет - пояс Койпера», которые формировались в протопланетном диске. В рамках развития гипотезы О.Ю. Шмидта и исследования подсистем обосновывается предположение существования за пределами пояса Койпера третьей подсистемы «группа разряженных поясов - третий пояс», которая формировалась за пределами протопланетного диска. Рассматривается наблюдаемая закономерность увеличения расстояний главного пояса и пояса Койпера в соотношении равном постоянному числу двадцать. Получено расстояние третьего пояса, которое согласно постоянной больше расстояния пояса Койпера в двадцать раз и равно 1000 a.e. и Седна «V774104» является его первым открытым удаленным объектом. Существование группы разряженных поясов подтвердили «Вояджеры», которые находятся в ее первом поясе. Получена модель гармоничного строения всей Солнечной системы и новые параметры ее окраины.

Ключевые слова: Солнечная система, объект Седна, пояс астероидов, пояс Койпера, третий пояс, группа пылевых поясов, подсистема, постоянная групп, постоянная систем. О.Ю. Шмидт.

\section{Введение}

По гипотезе О.Ю. Шмидта Солнечная система формировалась в пределах протопланетного диска, расстояние окраины которого равно расстоянию пояса Койпера и поэтому окраина Солнечной системы определяется его расстоянием , предположительно 50 а.е.. Однако открытый удаленный объект Седна, приближается к Солнцу на расстояние не ближе чем на 76 а.е., а удаляется на расстояние около 1000 a.e. Одни астрономы относят открытые удаленные объекты к внутренней части облака комет Оорта, а другие их относят к объектам рассеянного диска, находящегося между поясом Койпера и облаком комет Оорта. Автор открытия объекта Седна Майкл Браун выдвинул ошибочную идею о существовании девятой планеты «Планеты-Х», которая когда то удалила эти объекты из пояса Койпера.

В целях решения данной проблемы автор обосновывает, что Седна формировалась за пределами протопланетного диска и к поясу Койпера никакого отношения не имеет.

В строении Солнечной системы автор рассматривает две подсистемы «группапояс»: подсистему «внутренняя группа планет - пояс астероидов» и подсистему «внешняя группа планет - пояс Койпера». В подсистеме группа планет формировались путем их аккумуляции в группах поясов, которые были ранее формированы механизмом в протопланетном диске. В рамках развития гипотезы О.Ю. Шмидта и исследования расстояний подсистем обосновывается существование третьей подсистемы «группа разряженных поясов - третий пояс, которая формировалась за пределами протопланетного диска. Получен фундаментальный вывод о том, что Солнечная система формировалась в протопланетном диске и за его пределами. 
1. Аккреция группы планет в группе поясов.

В работе [1] получено, что в подсистеме, группа планет формируется совместно с поясом. Следовательно, наблюдаемые группы планет по четыре планеты в группе являются закономерными образованиями в Солнечной системе, а не случайным явлением. Обосновывается, что наблюдаемая закономерность увеличения расстояний планет в группах в соотношении близким числу два так же не случайна. В таблице 1 приводятся соотношения расстояний соседних пар планет в группах.

Таблийа 1

Соотношения «b» фактических расстояний планет в группах

\begin{tabular}{|c|c|}
\hline $\begin{array}{c}\text { Пары планет } \\
\text { Внутренней группь }\end{array}$ & $b$ \\
\hline Венера-Меркурий & 1,87 \\
\hline Земля-Венера & 1,38 \\
\hline Марс-Земля & 1,52 \\
\hline
\end{tabular}

\begin{tabular}{|c|c|}
\hline $\begin{array}{c}\text { Пары планет } \\
\text { Внешней группьь }\end{array}$ & $b$ \\
\hline Сатурн-Юпитер & 1,84 \\
\hline Уран-Сатурн & 2,0 \\
\hline Нептун-Уран & 1,58 \\
\hline
\end{tabular}

Наблюдаемые соотношения расстояний пар планет в группах близки к числу два и это свидетельствуют о том, что группы планет формировались группами путем аккреции в группе поясов, расстояния которых имели соотношение равное постоянному числу два. Получен механизм, который действительно формировал группы планет так, что расстояния поясов в группе имели соотношение равное постоянному числу два:

$$
R_{n+1} / R_{n}=2
$$

где:

$\boldsymbol{R}_{\boldsymbol{n}}-$ расстояние предыдущего пояса в группе протопланетных поясов.

$\boldsymbol{R}_{\boldsymbol{n}+\boldsymbol{1}}-$ расстояние последующего пояса группы протопланетных поясов.

За время аккреции планеты гравитационным взаимодействием отклонялись от соотношения средних расстояний своих поясов и расстояния планет установились в соотношении близким числу два, что и наблюдаем. Таким образом, впервые раскрыта тайна возникновения наблюдаемой закономерности в расстояниях планет в группах. Существование колец и поясов в протопланетном диске Солнца, подтверждено их открытием в протопланетном диске звезды TW Гидры и других звезд.

2. Группа разряжонных поясов третьей подсистемы.

В третьей подсистеме группа разряженных поясов сформирована за пределами протопланетного диска и поэтому в ней аккреция группы планет не состоялась. Установлено, что планеты формируются только группами и только в пределах протопланетного диска. За пределами пояса Койпера девятой планеты быть не может. Сегодня Вояджеры находятся в первом поясе группы разряженных поясов на расстоянии 120 a.e. от Солнца и ее существование подтверждают показания приборов об увеличении плотности.

3. Третий пояс третьей подсистемы и его расстояние

Совместное формирование в подсистеме группы поясов с поясом приводит к выводу о существовании закономерности увеличения в расстояниях пояса астероидов и пояса Койпера и их соотношения. Рассматривая расстояние пояса Койпера равное 50 a.e., а расстояние главного пояса равное 2.5 а.е., получим соотношение их расстояний равное числу двадцать.

Соотношение имеет следующий вид:

$$
\mathrm{Rn}+1 / \mathrm{Rn}=20
$$

где:

$\boldsymbol{R}_{\boldsymbol{n}}-$ расстояние главного пояса, 
$\boldsymbol{R}_{\boldsymbol{n}+\mathbf{1}}-$ расстояние пояса Койпера,

20 - соотношения расстояний.

Следовательно, расстояние пояса Койпера в двадцать раз больше расстояния пояса астероидов. Соотношение равное постоянному числу двадцать соответствует и расстоянию третьего пояса Солнечной системы, расстояние которого в двадцать раз больше расстояния пояса Койпера и равно 1000 а.е.. Известно, что на это расстояние удаляется открытый объект Седна, который является первым отрытым объектом третьего пояса . Открытие других удаленных объектов подобных объекту Седна подтверждают гипотезу существования третьего пояса в Солнечной системе. Перечень открытых объектов третьего пояса приводится в таблице 2.

Таблица 2

Удаленные объекты третьего пояса

\begin{tabular}{|c|c|c|c|c|}
\hline № & Объекты & Обозначение & $\begin{array}{c}\text { Перигелий } \\
\text { а.е. }\end{array}$ & $\begin{array}{c}\text { Арелий } \\
\text { a.e }\end{array}$ \\
\hline 1 & (Седна) & $(2003 / 2015)$ & 76 & +1000 \\
\hline 2 & 2013 SY99 & $2013 / 2017$ & 50 & 1400 \\
\hline 3 & Far Far Out & $+100(2018)$ & 130 & +1000 \\
\hline 4 & V774104 & $80(2015)$ & 80 & +1000 \\
\hline 5 & 2018 VG18 & $120(2019)$ & 120 & +1000 \\
\hline 6 & 2012 VP113, & $80(2912)$ & 70 & 1000 \\
\hline
\end{tabular}
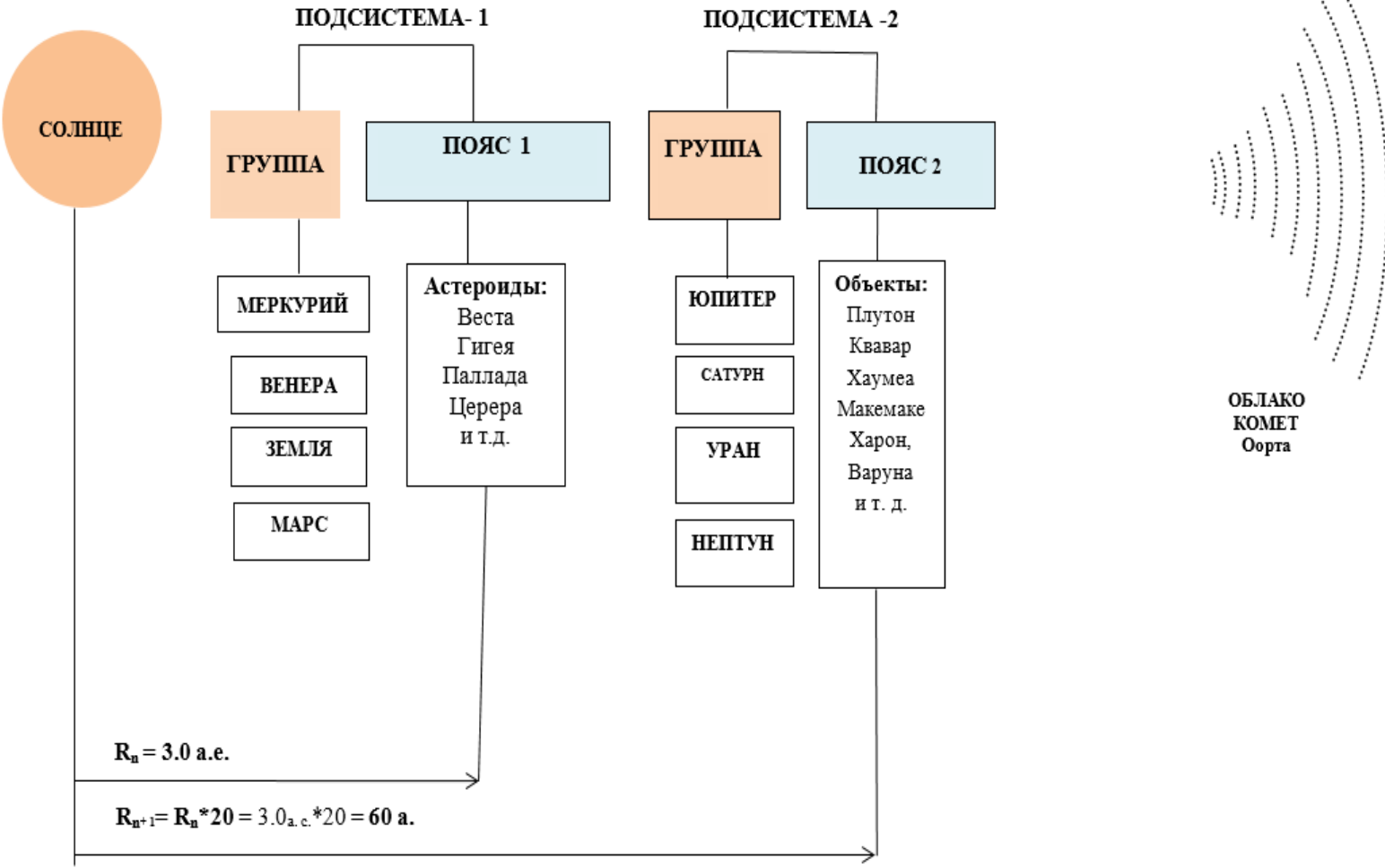

Рисунок 1. Модель строения Солнечной системы из двух подсистем

По существующему ошибочному представлению на окраине Солнечной системы между поясом койпера и облаком комет Оорта существует единый рассеянный диск, который показан на рисунке 2 . 


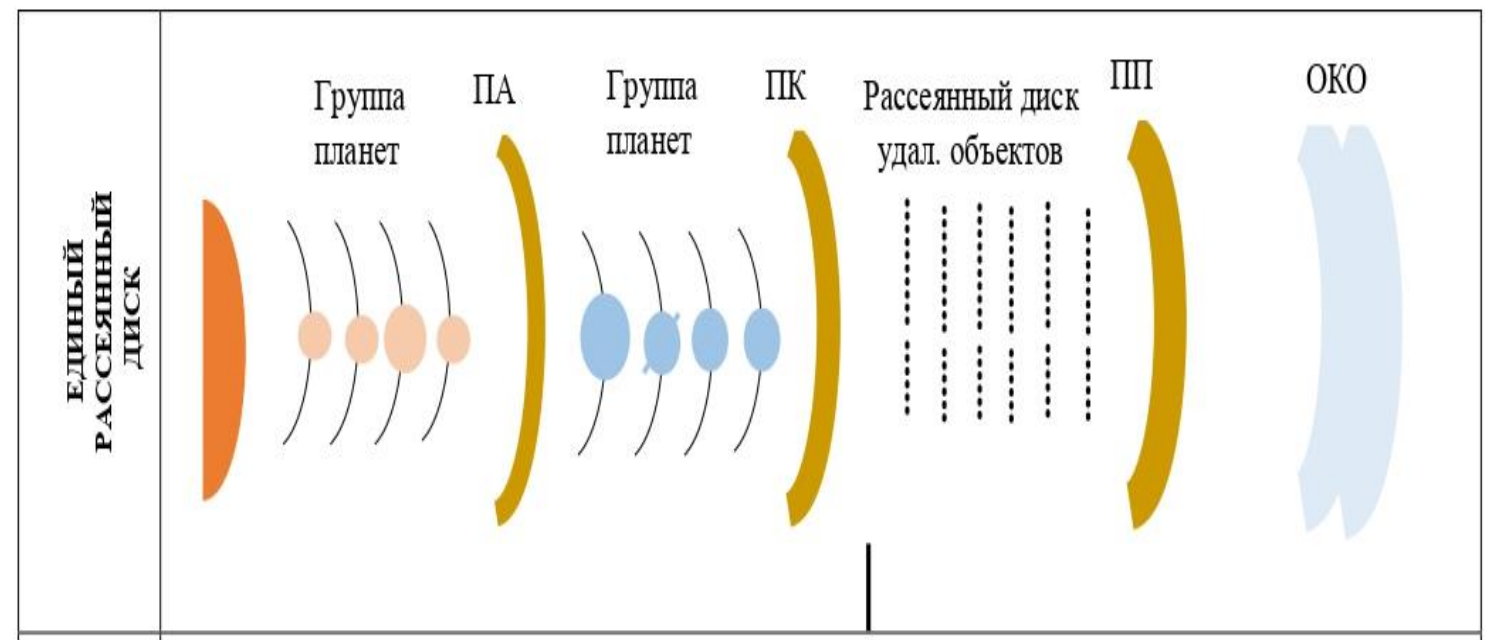

Рисунок 2. Показан не существвующий единый рассеянный диск

На рисунке 3 показано, что между поясом Койпера и облаком комет Оорта находится третья подсистема из группы разряженных поясов и третьего пояса (гипотеза Плеханова). Существование третьего пояса подтверждено открытием объекта Седна, который является первым открытым объектом его внутреннего рассеянного диска. Открыты удаленные объекты его внешнего рассеянного диска.

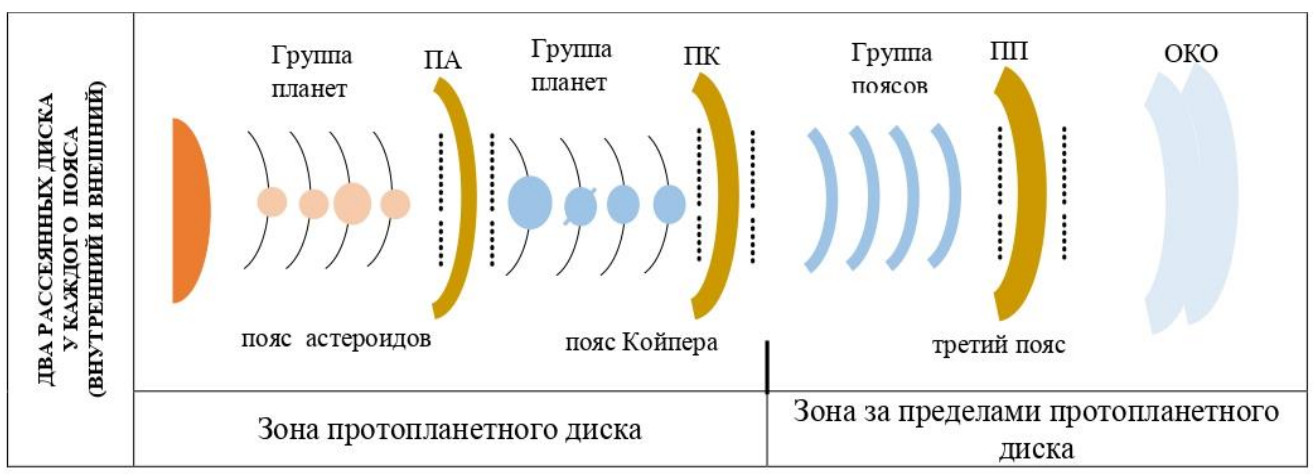

Рисунок 3. Расположение трёх поясов Солнечной системы и их рассеянных дисков

На рисунке 3 линиями из точек показаны внешние и внутренние рассеянные диски удаленных астероидов главного пояса и удаленных объектов пояса Койпера. Так открытый удаленный объект Эрида имея перигелий 35а.е., а афелий 132 относится к внешнему рассеянному диску пояса Койпера.

4. Модель строения всей солнечной системы

Таким образом в работе получена модель строения всей Солнечной системы в строении которой наблюдаем три полсистемы «группа - пояс»: подсистему «внутренняя группа планет - пояс астероидов», подсистему «внешняя группа планет пояс Койпера», подсистему «группа рассеянных поясов - третий пояс (гипотеза Плеханова)» и облако комет Оорта. Внутренняя часть облака имеет зону Хилса, а на внешней его части имеются рукава комет межзвездного пространства, которые наблюдаем у облака комет других звезд. Согласно постоянной равной числу двадцать получено расстояние облака комет Оорта, которое в двадцать раз больше расстояния третьего пояса и равно 20000 а.е. от Солнца. Это расстояние соответствует расстоянию облака полученного Яном Оортом.

Научное значение третьего пояса

Научное значение имеет впервые полученная модель строения всей Солнечной системы из трех подсистем, которые являются основой ее гармоничного строения. Модель открывает новые направления исследования строения подсистем и процессы 
совместного формирования в подсистемах группы и пояса. Определены зоны обитания открытых удаленных объектов и вековую тайну возникновения наблюдаемой закономерности увеличения расстояний планет в группах. Приводятся ранее не известные факты и закономерности, которые приводят к развитию научного представления о гармоничном строении всей Солнечной системы и раннем периоде ее формирования. В работах [2;7] установлены процессы формирования групп планет и постоянные Солнечной системы.

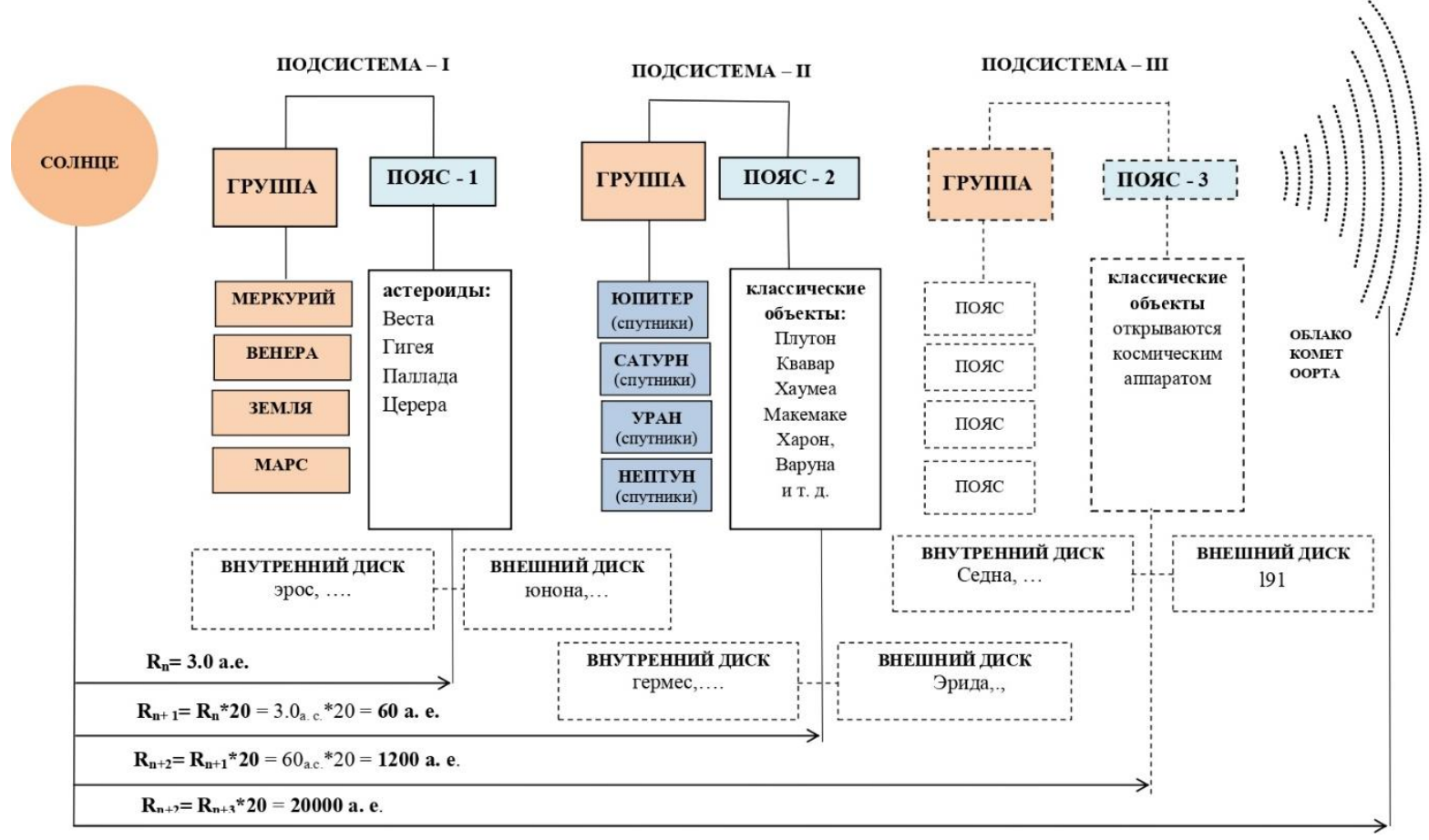

Рисунок 4. Модель гармоничного строения всей Солнечной системы и три ее подсистемы

$* * *$

1. Плеханов П.Г. Солнечная система - строение и кометная гипотеза происхождения: монография Самара: Издательство Инкома - пресс 2011 - 116с.

2. Плеханов П.Г. Механизм формирования группы из четырех протопланетных поясов - зоны аккумуляции группы планет. Доклады научной конференции СМК выпуск 5 - 2009 год стр. 82-91.

3. Уральская В.С. Крупнейшие транснептуновые объекты - Журнал 3/В 2006 №2.

4. Шмидт О.Ю. Четыре лекции о происхождении Земли /АН СССР 1957. 532.2.6;

5. Плеханов П.Г. Солнечная система XXI века: монография - Самара: Издательство СГПУ. 2003. $194 \mathrm{c}$.

6. Плеханов П.Г. Механизм формирования группы из четырех поясов - зоны аккумуляции группы планет. Доклады научной конференции СМК выпуск 2009 год стр. 82-91

7. Плеханов П.Г. Научное определение понятия планета

8. Шмидт О.Ю. О планетных расстояниях / ЛАН СССР, 1944 Том 46, №9

9. Шмидт О.Ю. Четыре лекции о происхождении Земли /АН СССР 1957

10. Рудницкий Г.М. Новые открытия внесолнечных планет -Ж 3/В 3, 2011.

11. Эйсмонт Н. Планета гигант на окраине Солнечной системы : математическая модель или реальность ? Наука и жизнь, №6, 2016 стр. 2-7.

12. Шмидт О.Ю. Четыре лекции о происхождении Земли /АН СССР 1957. 532.2.6;

13. У Уальская В.С. Крупнейшие транснептуновые объекты - Журнал 3/В 2006 №2. 


\title{
SECTION VII. EARTH SCIENCES
}

\author{
Kharchenko I.Ya., Kharchenko A.I. \\ Technologies for the formation of soil-cement massifs when developing underground \\ space in reclaimed lands and artificial islands \\ National Research Moscow State University of Civil Engineering" (NRU MGSU) \\ "Gorgeostroy» \\ (Russia, Moscow)
}

doi $10.18411 / g q-15-10-2021-13$

\section{Abstract}

In order to harden or increase the soil impermeability formed when constructing hydraulic territories, injection cement-grouting technology can be effectively applied. Its obvious advantages include environmental safety, manufacturability, durability, and economic attractiveness. The soil conditions of artificial territories are characterized by extreme uniformity, which necessitates the use of various technical solutions for their hardening. The experience of applying various soil injection cement-grouting technologies that provide the specified efficiency of the design decisions made has been analyzed in the report.

Keywords: soil-cement, injection technology, cement-grouting, reclaimed soil, artificial islands, activated slag, calcium sulfate.

\section{Introduction}

Currently, the practice of developing urban areas involves the formation of additional areas for the construction of buildings and structures of various purposes in the areas of rivers and seas in the form of artificial islands. An analysis of the experience in the construction and management of buildings built on artificial islands in Japan, Bahrain, Qatar, Russia, and other countries showed that the artificial islands were predominantly reclaimed soils mainly from medium-sized sands, less often - from small ones [1, 2]. In local zones, interlayers and lenses of sandy silt and clay soils are observed, which significantly reduce the bearing capacity of the artificial base [3, 4].

Groundwater in reclaimed lands lies at depths of 2 to $15 \mathrm{~m}$ depending on the thickness of the reclaimed strata and the distance from the boundaries of the water basin.

Reclaimed sands have a heterogeneous micro-layered structure, are characterized by medium density, and have the ability to compact and harden in time. Moreover, the duration of compaction without additional measures depends on the particle size distribution of the soil to be reclaimed, the applied method of reclamation and can be developed over a long time. (Table 1).

Engineering and geological properties of reclaimed soils are determined by their composition and physico-chemical interaction of mineral particles with water [5].. The composition of soils in a hydraulic dump will depend on the rock composition and occurrence modes in natural conditions, technological factors (the method of hydraulic overburden removal; the method of releasing the hydraulic mixture onto the reclamation area; the intensity of reclamation works), and the chemical composition of pore water [6].

The composition of the mineral and organic components of reclaimed soils determines the nature of the structural bonds and the time they acquire the specified physical and mechanical properties. When reclaimed, the hydraulic mixture (water-soil) is divided into fractions. Coarse particles are concentrated near the discharge of the hydraulic mixture, i.e., where a sloping zone is formed. Fine-sandy dusty particles predominantly form the intermediate zone and the thinnest (clay and dusty) particles form the hog box zone of the hydraulic reclaimed facility $[7,8]$. 
Three stages of formation of properties of reclaimed soils are distinguished: compaction, hardening, and stabilization.

After the formation of reclaimed soils - sedimentation associated with the precipitation of mineral particles from the stream of the hydraulic mixture entering the reclamation area, the soil is in a state close to complete water saturation and has very fluffy consistency (the degree of water saturation $\mathrm{Sr}$ of the reclaimed sands in this case does not fall below 0,8 ), the compaction stage begins. The increase in density is achieved due to gravitational compaction; filtration soil compression in the process of intensive water loss; capillary-meniscus soil compression under the influence of capillary pressure. During this period, the bulk of selfcompaction of reclaimed soils occurs. For most reclaimed sands, the duration of the stage does not exceed 1 year.

The hardening stage is characterized by the continuation of the acquisition of the strength properties of reclaimed soils due to the infiltration compression of sand and the static pressure of the upper layers of the reclamation and mudding. Between particles, various types of cementing bonds arise, and increased strength and dynamic stability are acquired. The duration of the stage is from 1.5 to 3 years.

At the stabilization stage, soil hardening continues to form due to the formation of water-resistant cementing bonds. The process is fading. At the end of this stage, reclaimed sands already belong to the category of significantly hardened ones and, according to strength indicators, approach Late Quaternary alluvial sands. The stabilization and hardening period is 10 years or more.

Table 1

The change in the deformation modulus $(\mathrm{MPa})$ of slightly wet sand without additional measures

\begin{tabular}{|c|c|c|c|c|c|}
\hline \multirow{2}{*}{ Soil } & \multicolumn{5}{|c|}{ Age of reclaimed sand, year } \\
\cline { 2 - 6 } & 0,1 & 0,5 & 1 & 3 & 5 \\
\hline Medium sand & 18 & 29 & 35 & 42 & 45 \\
\hline Fine sand & 12 & 22 & 28 & 36 & 40 \\
\hline
\end{tabular}

As can be seen from Table 1, the process of restoring disturbed natural structural bonds of reclaimed soils can be developed over a sufficiently long period of time. This does not allow, in the conditions of changing soil properties, carrying out the design of bases and foundations of buildings and structures, by relying on reliable calculation methods, which is a significant limiting factor when developing artificial territories.

In this regard, the task of artificial transformation of the properties of reclaimed soils in accordance with design requirements, which are determined by the design features of the buildings and structures being erected, is of particular relevance. In addition, an important feature of the development of the territories of artificial islands, the building density of which, as a rule, is not less than $1.5 \ldots 2.2$ times higher compared to natural territories, should be noted. Given the rather limited areas of reclaimed territories, they are built up mainly with high-rise buildings with multi-storey underground garages. Artificial transformation of the properties of reclaimed soils should not only ensure the achievement of high strength and deformation characteristics but also their high water resistance and corrosion resistance, given the increased aggressiveness of groundwater.

\section{Technological basis of soil consolidation grouting}

The technical and economic efficiency of soil consolidation grouting is confirmed by many years of geotechnical construction practice $[9,10,11]$. When developing the underground space in difficult geotechnical conditions, among the variety of cement grouting technologies, the following ones are most common:

- injection grouting in the mode of impregnation of the pore structure of the soil using finely dispersed binders (microcement) and cuff technology; 
— jet grouting of soils using one- and two-component technology (“Jet-1" and "Jet-2");

- combined soil grouting technology, combining the Jet-2 two-component grouting technology followed by the impregnation with microcement-based injection mixture using the Super-Jet cuff technology.

Each of the above technologies has an optimal field of application, taking into account geotechnical conditions and architectural and structural features of buildings and structures $[11,12]$. Currently, common cement, special microcement, activated bentonites, mineral microfillers, as well as their combinations are used for soil grouting [11, 13].
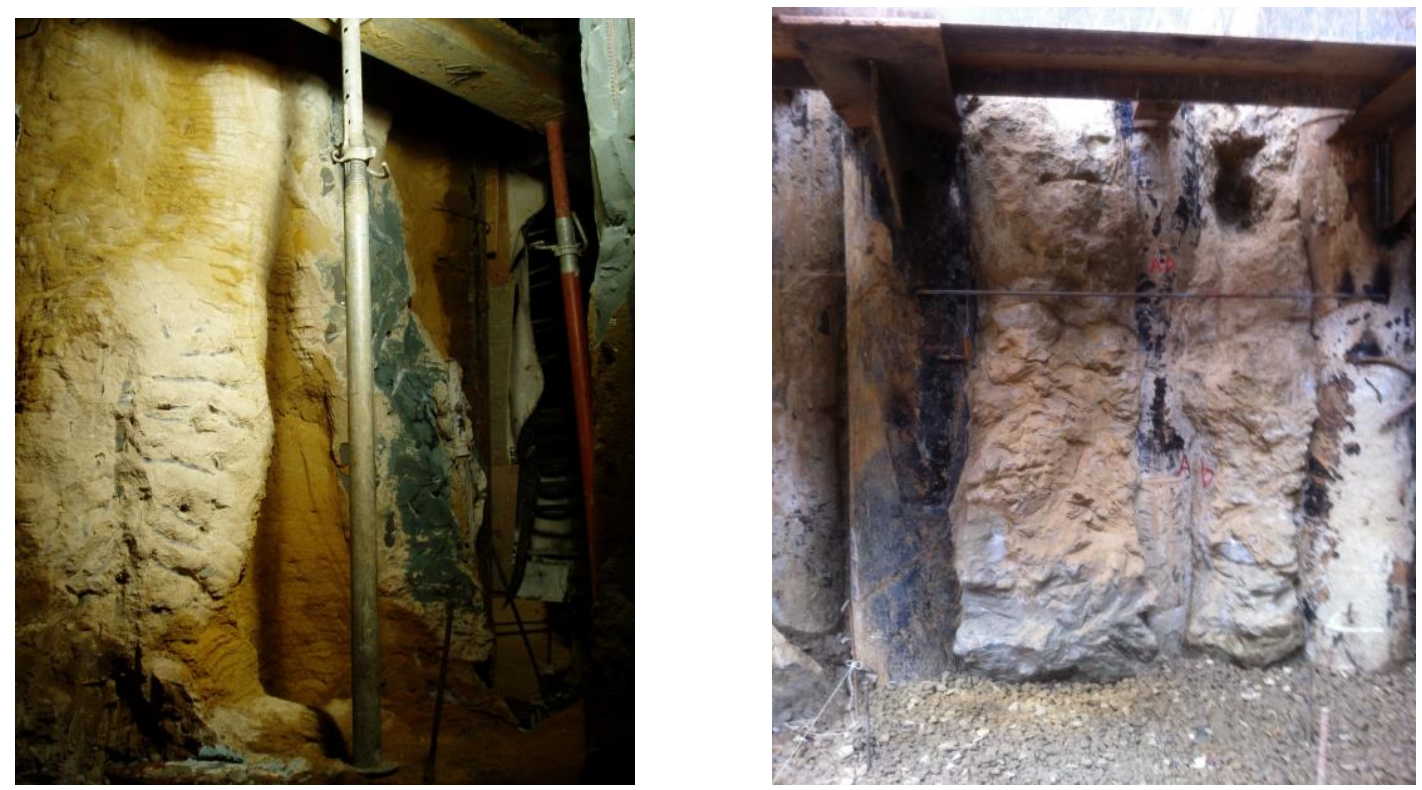

Figure 1. The view of the grouted soil sections using impregnation (left) and jet (right) cement grouting

The soil-cement grouting using microcements in accordance with to the cuff technology in the impregnation mode is the most sparing method for the existing building, provides a high strength of the cement-bound massif reaching $20 \mathrm{MPa}$ and higher, water resistance, significant dimensions, and uniformity. However, this technology is applicable only in sandy soils with a filtration coefficient of at least $0.5 \mathrm{~m} /$ day.

The Jet-1 one-component grouting technology is acceptable for a wide range of soils, has high productivity, and provides a sufficiently high strength of the soil-cement massif but has a small diameter of soil-cement piles, not exceeding $0.6 \ldots .0 .8 \mathrm{~m}$. In this regard, the construction of a continuous soil-cement massif involves a significant amount of drilling and cement grouting works. The use of the two-component jet grouting technology (Jet-2) provides the formation of soil-cement piles with a diameter of up to $1.8 \ldots 2.0 \mathrm{~m}$. However, the strength of the soil-cement massif, as a rule, does not exceed 1-3 MPa due to increased air involvement in the structure of the grouted soil. It does not have sufficient strength and water resistance. In addition, due to the significant dimensions of the processing equipment and the need to remove significant volumes of soil-cement slurry from the construction site, the jet grouting is of limited use in confined spaces $[14,15]$.

Table 2

Some process parameters of soil-cement grouting technologies

\begin{tabular}{|c|c|c|c|c|}
\hline $\begin{array}{c}\text { Type of soil-cement } \\
\text { grouting technologies }\end{array}$ & $\begin{array}{c}\text { Impregnation } \\
\text { injection }\end{array}$ & $\begin{array}{c}\text { Jet grouting } \\
\text { «Jet-1» }\end{array}$ & $\begin{array}{c}\text { Jet grouting «Jet- } \\
2 »\end{array}$ & $\begin{array}{c}\text { Combined } \\
\text { technology «Super- } \\
\text { Jet" }\end{array}$ \\
\hline Type of soils to be grouted & $\begin{array}{c}\text { Sands, light } \\
\text { loamy sand }\end{array}$ & $\begin{array}{c}\text { Sand, loamy } \\
\text { sand, loam, } \\
\text { clay }\end{array}$ & $\begin{array}{c}\text { Sand, loamy sand, } \\
\text { loam, clay }\end{array}$ & $\begin{array}{c}\text { Heavy loamy sand, } \\
\text { loam, clay }\end{array}$ \\
\hline
\end{tabular}




\begin{tabular}{|c|c|c|c|c|}
\hline $\begin{array}{c}\text { Maximum compressive } \\
\text { strength of the soil-cement } \\
\text { massif, }(\mathrm{MPa})\end{array}$ & 30 & 15 & 3 & 10 \\
\hline $\begin{array}{c}\text { Maximum radius of } \\
\text { grouting, }(\mathrm{m})\end{array}$ & 0,8 & 0,4 & 0,9 & 1,0 \\
\hline $\begin{array}{c}\text { Maximum intensity of soil } \\
\text { grouting, }(\mathrm{l} / \mathrm{min})\end{array}$ & 15 & 100 & 500 & no \\
\hline $\begin{array}{c}\text { Pre-arrangement of the } \\
\text { well with a cuff string }\end{array}$ & yes & no & 200 & 200 \\
\hline $\begin{array}{c}\text { Sludge outlet volume } \text { per } 1 \\
\text { m3 of soil grouting, }(l)\end{array}$ & 0 & 200 & 450 & $400 / 150$ \\
\hline $\begin{array}{c}\text { Binder consumption } \text { per } 1 \\
\text { m3 of grouted soil, }(\mathrm{kg})\end{array}$ & $75-100$ & 450 & 50 \\
\hline
\end{tabular}

Table 2 shows that each of the above technologies has its advantages and disadvantages when grouting reclaimed soils. In this regard, the combination of separate technological elements can be the optimal solution, which allows realizing the advantages of various technologies in the maximum volume. In particular, the combined Super-Jet technology, which involves a combination of two-component jet grouting technology (Jet-2) and impregnation technology, aims to combine the high intensity of work production, which is a significant advantage of two-component jet grouting, with the need to give the grouted massif the increased strength and impermeability, which is achieved by applying the impregnation technology.

Technological combination of technologies occurs in the following sequence.

1. Two-component jet grouting of the soil massif using the Jet-2 technology.

2. Submergence into the well, through which the soil-cement massif and a cuff pipe (from PVC pipes $\varnothing 50 \mathrm{~mm}$ ) with a spacing of expanding cuffs of 330 $\mathrm{mm}$ (3 horizons per $1 \mathrm{~m}$ of column height) were formed. The cuff is immersed in the design depth manually in the range of $30 \ldots 90$ min after the end of jet grouting.

3. Curing of the soil-cement massif until the cement setting process is completed, which is determined experimentally.

4. Cement grouting of the soil-cement massif along the cuff pipe horizons from bottom to top (using a two-sided hose seal) with a suspension of a finely-dispersed binder with a water binder ratio $\mathrm{W} / \mathrm{B}=3.0 \quad \ldots 4.0$, depending on the required strength. The injection volume per $1 \mathrm{~m}^{3}$ of the soil-cement massif is calculated from the volume of its pore space and is, as a rule, from 250 to 300 liters. The impregnation mode is regulated simultaneously according to 2 parameters: discharge intensity and discharge pressure.

The technology of the combined grouting is recommended for use in the case of alternating layers of sandy and clay weak waterproof soils using the cuff technology. At the same time, in layers of sandy pervious soil with a filtration coefficient of more than $0.5 \mathrm{l} / \mathrm{min}$, the injection of the finely-dispersed binder is applied in the impregnation injection mode with the injection intensity from 0.5 to $3.01 / \mathrm{min}$ at a pressure of up to $0.5 \mathrm{MPa}$. In clay impervious soil layers (heavy loamy sand, loam, clay) with a filtration coefficient of less than $0.51 / \mathrm{min}$, the injection of the finely-dispersed "Microdur-X" binder is used in compressionburst injection mode with the injection rate of 0.2 to $1.01 / \mathrm{min}$ at a discharge pressure of up to $1.0 \mathrm{MPa}$.

\section{Materials and research methods}

When compacting and hardening soils by cement grouting methods, cement consumption is $350 \ldots 900 \mathrm{~kg} /$ cubic meter of the grouted soil depending on the design requirements and geotechnical conditions of construction. In this regard, the replacement of building Portland cement with a slag binder is a significant reserve for increasing the technical and economic efficiency of the soil compaction and hardening works using jet grouting technology. 
In addition, the feasibility of replacing the building Portland cement with the slag binder is due to the fact that groundwater in dense urban areas has increased aggressiveness with respect to cement concrete and, conversely, can be an additional activating factor when using slag binders. The theoretical foundations of the use of activated slag in construction are described in the works of G. Kyul, Ya. Davidovich, V.G. Glukhovsky /1,2,3/. In particular, Ya. Davidovich introduced the concept of geopolymer systems based on alkaline activation of metakaolin with the formation of aluminosilicate polymers. Currently, various methods for the activation of slags and ashes, providing for a mechanical, chemical, or mechanochemical effect on their structure, have been investigated and developed. The sulfate activation based on the mixing of ground slag and gypsum is one of the effective ways to activate blast furnace granulated slag.

In order to evaluate the effectiveness of the use of slag binders for compaction and hardening of soils, a complex of studies on the properties of the composite binder based on ground granulated slag activated by calcium sulfate and soil-concrete both in the laboratory and in the field was carried out. The studies were carried out using slag milled to a specific surface of $4,600 \mathrm{~cm}^{2} / \mathrm{g}$. The hydraulic activity of the slag was evaluated in accordance with DIN 1164. Gypsum anhydrite or two-water gypsum was used as a sulfate activator. In order to further activate hydration processes, calcium hydroxide in an amount of up to $10 \%$ was introduced into the composition of the composite binder. For research, a solution of W/B = 0.35 was used. Studies of the construction and technical properties of the composite binder were carried out by using a normal density cement test. The cast cement-bound mixture, prepared in a forced-action mixer, was poured into ordinary $7 \times 7 \times 7 \mathrm{~cm}$ cubes and pressed without vibration (self-sealing, under the influence of gravity alone). The actual compressive strength of soil concrete at a design age of 28 days ( $\mathrm{Rf}$ ) was determined according to GOST 10180-90 "Concretes. Methods for determining the strength of control samples" using the corresponding scale factor 0.85 .

In the experimental works, 40x40x160 $\mathrm{mm}$ and 70x70x280 mm beam samples were prepared from fine-grained concrete mixture with $\mathrm{C}: \mathrm{S}=1: 2$ at $\mathrm{W} / \mathrm{C}=0.4$.

Portland cement of the Belgorod plant with an activity of $52.4 \mathrm{MPa}$, with a normal density of $25.5 \%$, a true density of $3.1 \mathrm{~g} / \mathrm{cm}^{2}$, and a specific surface of $3450 \mathrm{~cm}^{2} / \mathrm{g}$ was used as a binder. Quartz sand with a fineness modulus of $\mathrm{Mkr}=2.2$, a true density of $2.45 \mathrm{~g} / \mathrm{cm}^{3}$, and a bulk density of $1.58 \mathrm{~kg} / 1$ was used as a filler.

\section{Results of experimental studies}

The results of the study of the influence of the ratio of components on the activity of the composite binder are presented in Figure 1 and Figure 2.

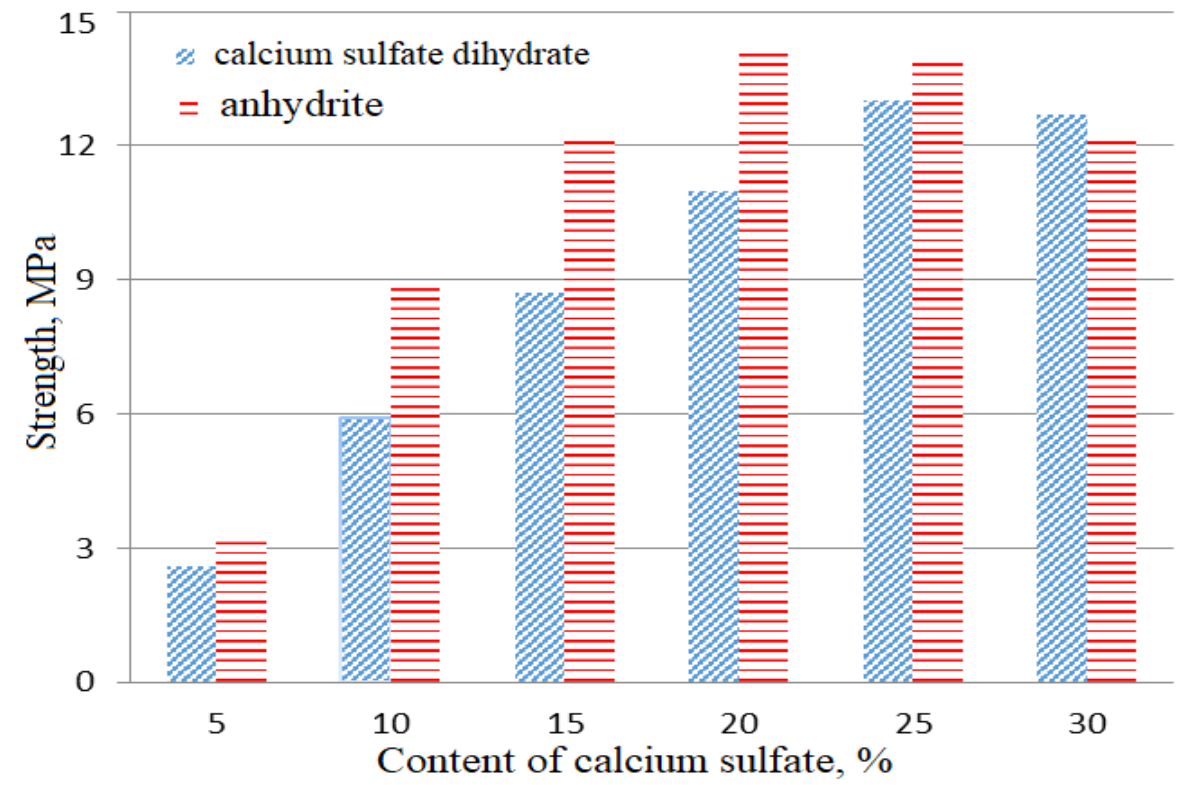

Figure 2. The effect of calcium sulfates on the hydraulic activity of the ground slag (28 days of normal hardening) 


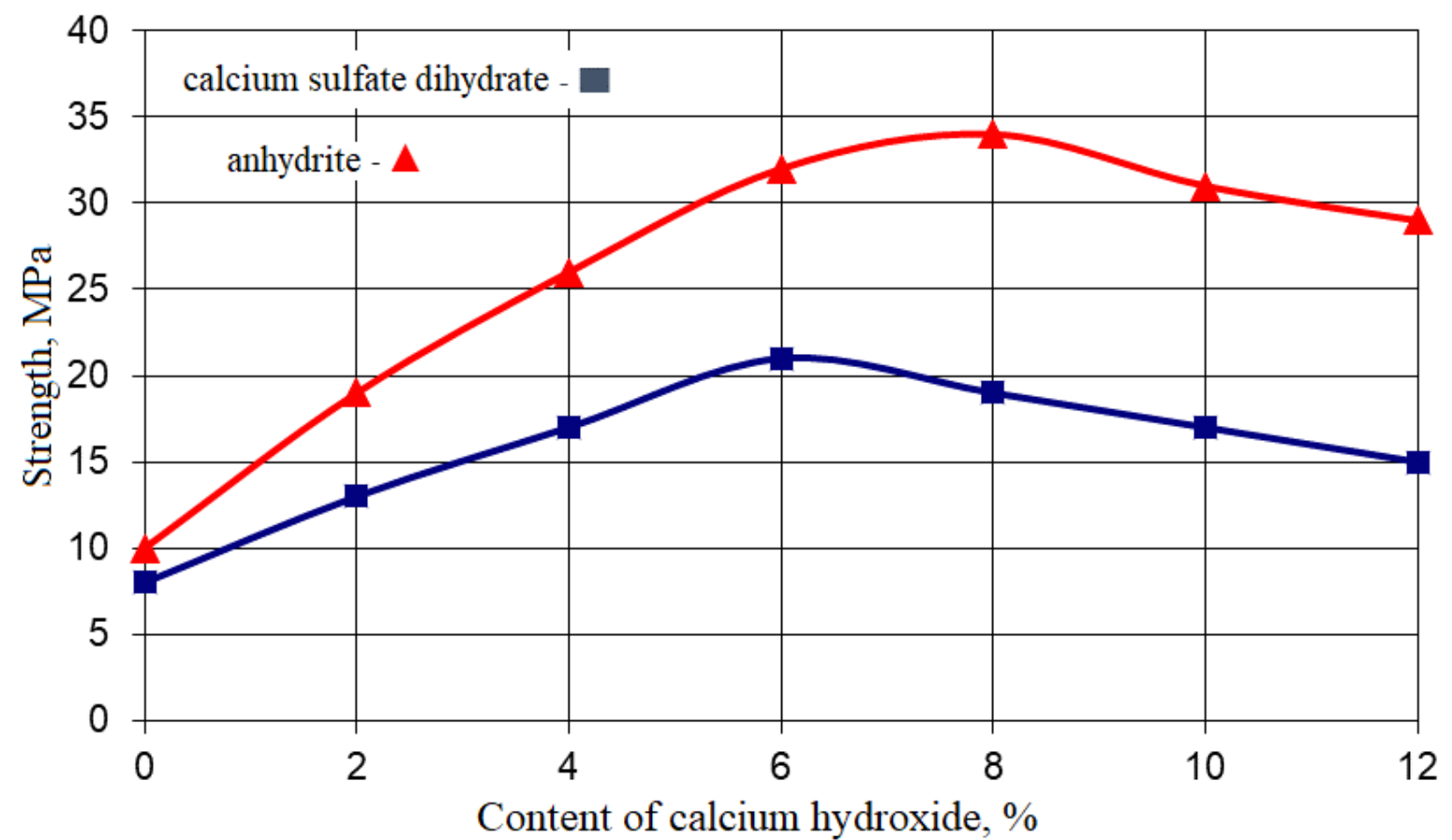

Figure 3. The effect of calcium hydroxide on the strength of slag with a sulfate activator (calcium sulfate - 20\%) at the age of 28 days of normal hardening

Based on the analysis of the results of experimental studies, it was found that sulfate activation based on gypsum anhydrite is more effective compared to activation based on bipartite gypsum. Moreover, if, when using anhydrite, its optimal content is within 15-20\% of the mass of slag, then for two-water gypsum its effective content is limited to $25-30 \%$. This is due to the difference in the mechanism of interaction of the sulfate component with slag, as well as a significant difference in their solubility.

With the additional introduction of calcium hydroxide into the sulfate-slag mixture, the activity of the composite binder increases significantly. Based on the analysis of the results of experimental studies, it was found that for a slag mixture with both anhydrite and gypsum, the optimal consumption of calcium hydroxide in the composition of the composite binder is $5-7 \%$. A further increase in the content of calcium hydroxide in the composition with anhydrite is not accompanied by an increase in compressive strength, and, in the presence of two-water gypsum, the strength decreases.

Compositions of the composite binder based on slag activated by anhydrite and calcium hydroxide underwent production testing when grouting waterlogged sandy soil under the Jet-1 one-component cement grouting technology using cement-water mortars with W/C = $0.8 \ldots 1.2$.

When analyzing the processes of structure formation and the properties of soil concrete, it seems possible to apply the well-known theoretical foundations developed for fine-grained concrete. In this case, when considering the design, selection, and regulation of the composition of composite binders for grouting of soils, the forecast and control of its strength, composition, and durability (corrosion resistance and frost resistance) of soil concrete, it is necessary to take into account the peculiarities of soil grouting using the jet technology. Such a method, with all its advantages, has boundaries between the fundamental differences between the jet technology and the traditional application of concrete technology, among which two of its features are most needed:

- soil-cement fillers are represented by elements of the natural structure of the soil with the possible inclusion of clay agglomerates;

— in jet technology, cement mixtures with significantly higher water content are used in comparison with conventional concrete technology; 
- when designing the composition of injection mixtures, the natural water saturation of the soil structure should be taken into account.

Thus, the characteristics of soil concrete in jet technology can significantly differ from the properties of fine-grained cement concrete prepared in the traditional way with comparable values of W/C and cement consumption. In this case, the soil should be considered as a filler of soil concrete, consisting of two parts:

1) non-cohesive soil, represented by sands with randomly organized particle size and mineral composition;

2) inclusions, consisting of aggregates of cohesive soil.

As can be seen from Table 3, the main regularity of changes in the strength of soil concrete from W/B is maintained for soils with different water contents. It is important to know that the effect of W/B as a factor decreases with increasing the soil water content (Ws).

Table 3

The effect of W/B on the strength of soil based on slag binder

\begin{tabular}{|c|c|c|c|c|c|}
\hline \multirow{2}{*}{$W s, \%$} & \multicolumn{5}{|c|}{ Compressive strength of soil concrete, MPa, at various W/B } \\
\cline { 2 - 6 } & 0,8 & 0,9 & 1,0 & 1,1 & 1,2 \\
\hline 0 & 12,6 & 9,8 & 7,3 & 5,2 & 3,8 \\
\hline 5 & 9,4 & 6,2 & 5,1 & 3,1 & 1,4 \\
\hline 10 & 5,1 & 3,8 & 3,0 & 2,2 & 0,5 \\
\hline 15 & 2,2 & 1,8 & 1,2 & 0,8 & - \\
\hline 20 & 0,9 & 0,6 & 0,2 & - & - \\
\hline
\end{tabular}

Note: Composition of the composite binder: $75 \%$ (slag) $+20 \%$ (anhydrite) $+5 \%$ (calcium hydroxide). The activity of the binder is $32 \mathrm{MPa}$. The binder consumption is $650 \mathrm{~kg} / \mathrm{m}^{3}$. Soil is fine-grained quartz sand. Compression strength at the age of 28 days.

The water content of cement-bound mixture formed by jet grouting technology can reach $3001 / \mathrm{m}^{3}$ or more, which significantly exceeds the water content of fine-grained concrete mixtures. The consequence of the increased water content of the cement-bound mixture is an increase in the volume and size of the capillary pores of the formed soil concrete, which reduces its strength characteristics. At the same time, the risk of delamination of cement-bound mixture and uniformity of the cement-bound massif increases, which negatively affects its structural quality. These characteristics of jet technology must be taken into account when calculating compositions and analyzing the properties of soil concrete.

Moreover, the factor determining the strength characteristics and uniformity of cement-bound massif is not the activity of the binder but the value of the water-binder ratio, which determines the amount of the binder in the composition of the cement-bound mixture $[11,14]$. In the practice of geotechnical construction, water-saturated or flooded soils are primarily subject to compaction, consolidation, and hardening. In this regard, the use of composite binders based on activated slag is more preferable in relation to conventional building types of cement.

Distinctive properties of the composite binder based on activated slag include a sufficiently high hydraulic activity; increased durability in aggressive environments; high sedimentation stability of the injection mixture; increased adhesive bond with soil structure elements; increased penetration into the soil structure due to the increased dispersion of the mineral binder. Due to the fact that the mineral base of the activated slag (AS) is homogeneous with the mineral composition of the soil, the cement-bound massif is formed during jet grouting of the soil using AS, which can be classified as a geopolymer massif with improved physical and mechanical characteristics.

As an analysis of the results of application by Gorgeostroy LLC shows, an injection mixture based on AS is characterized by a lower hydrodynamic resistance of the jet at the exit from the monitor, improved disaggregating effect on the soil structure, increased cohesion and stability of the cement-bound mixture, increased uniformity of the formed cement-bound massifs, and accelerated development of strength. 
The use of optimal AS-based formulations allows increasing the effective size of the formed cement-bound massifs with a simultaneous increase in their uniformity and continuity, which is a prerequisite for reducing the number of piles, reducing the cost and terms of work while improving quality.

The results of experimental studies and practical experience of application by Gorgeostroy LLC allow designing the composition and properties of AS-based soil concrete, designing compositions and process modes, predicting the kinetics of development of strength, porosity, impermeability, and durability of cement-bound massifs, as well as substantiating technical and economic efficiency use of AS for hardening and compaction of almost all types of soils with the design compressive strength in the range of $0.5 \ldots 10.0 \mathrm{MPa}$ when constructing the facilities of transport, special industrial, and general civil purposes on reclaimed soils.

\section{Conclusions.}

1. In order to strengthen or increase the impermeability of the soils formed during the construction of reclaimed territories, the injection cement grouting technology can be effective. Its obvious advantages are environmental safety, manufacturability, durability, and economic attractiveness.

2. Due to the fact that the mineral base of activated slag is homogeneous with the mineral composition of the soil, a cement-bound composite is formed during injection grouting, which can be classified as a geopolymer massive with enhanced physical and mechanical characteristics.

3. Introduction to the composition of the ground slag sulfate and calcium hydroxide provides its hydraulic activity, necessary for compaction and hardening of unbound water-saturated reclaimed soils using the jet grouting technology.

$$
* * *
$$

1. B. Butchibabu, Prosanta Kumar Khan, P. C. Jha. Foundation evaluation of underground metro rail station using geophysical and geotechnical investigations// Engineering Geology, Volume 248, 8 January 2019, Pages 140-154. DOI: 10.1016/j.enggeo.2018.12.001.

2. Jj Andrei Belyi, Eduard Karapetov, Yurii Efimenko. Structural Health and Geotechnical Monitoring During Transport Objects Construction and Maintenance (Saint-Petersburg Example) // Procedia Engineering, Volume 189, 2017, Pages 145-151. DOI: 10.1016/j.proeng.2017.05.024.

3. Javier Farfan, Mahdi Fasihi, Christian Breyer. Trends in the global cement industry and opportunities for long-term sustainable CCU potential for Power-to-X // Journal of Cleaner Production, Volume 217, 20 April 2019, Pages 821-835. DOI: 10.1016/j.jclepro.2019.01.226.

4. Dan Song, Ling Lin, Wei Bao. Exergy conversion efficiency analysis of a cement production chain // Energy Procedia, Volume 158, February 2019, Pages 3814-3820. DOI: 10.1016/j.egypro.2019.01.867.

5. Mohamed M. Elfaham, Usama Eldemerdas. Advanced analyses of solid waste raw materials from cement plant using dual spectroscopy techniques towards co-processing // Optics \& Laser Technology, Volume 111, April 2019, Pages 338-346. DOI: 10.1016/j.optlastec.2018.10.009.

6. Ekaterina Nezhnikova. The Use of Underground City Space for the Construction of Civil Residential Buildings // Procedia Engineering, Volume 165, 2016, Pages 1300-1304. DOI: 10.1016/j.proeng.2016.11.854.

7. Panchenko A.I., Kharchenko I.Ya., Alekseev S.V. Microcements. Publishing House ASV, Moscow 2014.

8. Dolev A.A., Kharchenko I.Ya. On the use of microcements in geotechnical construction // Geotechnics. 2013. No. 4. P. 32-36.

9. Dvorkin L.I., Dvorkin O.L. Building mineral binders. Moscow, 2013.

10. Panchenko A.I., Kharchenko I.Ya. Particularly finely-dispersed mineral binder Microdur: properties, technology, and prospects of use. Building materials, 2005, No. 10.

11. Kharchenko I.Ya., Alekseev V.A., Israfilov K.A., Beterbiev A.S.E. Modern technologies of soil grouting // Vestnik MGSU. 2017. No. 5 (104). P. 552-558. DOI: 10.22227/1997-0935.2017.5.552-558.

12. Zhi-Feng Wang, Shui-Long Shen, Giuseppe Modoni. Enhancing discharge of spoil to mitigate disturbance induced by horizontal jet grouting in clayey soil: Theoretical model and application // Computers and Geotechnics, Volume 111, July 2019, Pages 222-228. DOI: 10.1016/j.compgeo.2019.03.012. 
13. Mahdi Heidari, Fulvio Tonon. Ground reaction curve for tunnels with jet grouting umbrellas considering jet grouting hardening // International Journal of Rock Mechanics and Mining Sciences, Volume 76, June 2015, Pages 200-208. DOI: 10.1016/j.ijrmms.2015.03.021.

14. O. A. Makovetskiy. Application of "Jet Grouting" for Installation of Substructures of Estates // Procedia Engineering, Volume 150, 2016, Pages 2228-2231. DOI: 10.1016/j.proeng.2016.07.269.

15. G. G. Kashevarova, O. A. Makovetskiy. Analysis of Experimental and Estimated Jet-grouted Soil Mass Deformations // Procedia Engineering, Volume 150, 2016, Pages 2223-2227. DOI: 10.1016/j.proeng.2016.07.268.

16. Alekseev V.A., Kharchenko I.Ya., Kharchenko A.I., Bazhenova S.I., Beterbiev A.S.E. Modified concrete mixtures for spatial structures applied by spraying // Vestnik MGSU. 2016. No. 11. P. 48-58. DOI: 10.22227/1997-0935.2016.11.48-58

17. Kharchenko A.I., Alekseev V.A., Kharchenko I.Ya., Alekseev A.A. Application of slag-alkali binders in jet cement grouting for soil consolidation. Vestnik MGSU [Proceedings of Moscow 


\section{SECTION VIII. RESOURCE SAVING}

\section{Москаленко В.М. \\ Влияние скорости перехода на энергоэффективность морского судна}

МГУ им. адм. Г.И. Невельского

(Россия, Владивосток)

doi $10.18411 / g q-15-10-2021-14$

\section{Аннотация}

Проблема изменения климата накладывает существенные ограничения на развитие морского судоходства. Прежде всего, это касается обязательного планирования и расчета операционного коэффициента энергоэффективности в рейсе, с целью уменьшения выбросов $\mathrm{CO}_{2}$. С введением запрета на высокосернистое судовое топливо, с января 2020г. ситуация еще больше усугубилась, что требует от судовладельцев отказа от части прибыли в пользу удовлетворения ограничениям по энергоэффективности судна. В данной работе исследуется влияние транспортной работы судна, с точки зрения изменения скорости на переходе, на операционный коэффициент энергетической эффективности морского судна.

Ключевые слова: морское судно, выбросы $\mathrm{CO}_{2}$, энергоэффективность, эксплуатационная скорость.

Изменение климата рассматривается сегодня, как серьезнейшая угроза (с позиций рисков сдерживающих экономический рост) для всех государств. С принятием Парижского соглашения по климату 12 декабря 2015 года все стороны согласовали общий набор целей для решения проблем связанных с глобальным потеплением. Эти цели включают в себя долгосрочную цель по удержанию повышения глобальной средней температуры на уровне ниже $2 \mathrm{x}^{0} \mathrm{C}$, по сравнению с доиндустриальными уровнями и продолжение усилий по ограничению повышения температуры до $1,5{ }^{0} \mathrm{C}$ по сравнению с доиндустриальными уровнями [1]. Еще одна важная цель, это способность стран адаптироваться к негативным воздействиям изменения климата. Разумеется, как само изменение климата, так и предложенная энергетическая политика в ближайшее время будут накладывать значительные ограничения на глобальный экономический рост и внешнюю торговлю. Глобальные социально-экономические тенденции, рост населения, рост доходов и усиление урбанизации неизбежно ведут к увеличению спроса на электроэнергию, транспорт и другие энергоемкие услуги. Беспрецедентный рост мировой экономики за последнее столетие привел к увеличению использования сырьевых товаров и связанных с ними выбросов парниковых газов. Более высокие выбросы парниковых газов , в свою очередь, ускорили изменение климата, что отрицательно сказалось на самом производстве товаров.

Сегодня в научном сообществе существует устоявшееся мнение, что глобальное потепление, а также экстремальные и неблагоприятные изменения климата вызваны увеличением концентрации парниковых газов в атмосфере Земли. В частности, концентрация $\mathrm{CO}_{2}$ в атмосфере увеличилась на 31 процент с начала индустриализации (т.е. со второй половины двадцатого века), и выбросы $\mathrm{CO}_{2}$ составляют наибольшую долю в выбросах парниковых газов. При этом, самые большие выбросы происходят от сжигания нефти, природного газа и их производных. Глобальные выбросы от деятельности человека по секторам экономики представлены в табл.1.

Таблийа 1

Выбросы парниковых газов по секторам экономики [1]

\begin{tabular}{|c|c|c|}
\hline № & Источник выбросов & проценты \\
\hline 1 & Электричество и производство тепла & 25 \\
\hline
\end{tabular}




\begin{tabular}{|c|c|c|}
\hline 2 & Землепользование & 24 \\
\hline 3 & Промышленность & 21 \\
\hline 4 & Транспорт & 14 \\
\hline 5 & Прочая энергия & 10 \\
\hline 6 & Здания и сооружения & 6 \\
\hline
\end{tabular}

Обсуждение изменения климата связано с поисками способов уменьшить выбросы $\mathrm{CO}_{2}$ связанные с деятельностью человека. В этих условиях подсчитано, что пандемия коронавируса может спасти множество человеческих жизней за счет улучшения качества воздуха в городах [2]. Большое количество предприятий из-за пандемии вынужденно меняет логистику поставок, что в краткосрочной перспективе связано с уменьшением объемов внешней торговли на глобальных рынках. Тем не менее, начиная с 1990 года суммарное радиационное воздействие, вызывающее глобальное потепление, возросло на $43 \%$, где на $\mathrm{CO}_{2}$ приходится около 80 процентов прироста [3].

Морской транспорт лежит в основе глобальных цепочек поставок и экономической взаимозависимости с судоходством и портами, на которые, по оценкам, приходится более 80 процентов мировой торговли товарами по объему и более 70 процентов по совокупной стоимости товара. По оценкам ИМО выбросы парниковых газов с судов составляли в 2012г. около 2,2 процента антропогенных выбросов углекислого газа в мире [4]. На сегодня, выбросы от международного судоходства составляют уже около 4x процентов, а к 2050г. их объем может составить (по прогнозам) более 50 процентов [4]. По оценкам экспертов осуществление ряда технических и эксплуатационных мер может повысить энергоэффективность судов и сократить выбросы парниковых газов на 75 процентов.

После вступления в силу соответствующих поправок к приложению VI Международной конвенции МАРПОЛ 78 по предотвращению загрязнения с судов, меры по повышению энергоэффективности стали юридически обязательными в морской отрасли, для судов валовой вместимостью 400 и более регистровых тонн, с 1 января 2013г. На судне должен находиться план управления энергоэффективностью (SEEMP), который может быть частью судовой системы управления безопасностью или системы экологического менеджмента по ISO 14001. Этот план должен быть направлен на уменьшение выбросов с судов $\mathrm{CO}_{2}$ за счет более рационального использования топлива и планирования рейса. Для этого производят расчеты эксплуатационного индекса энергетической эффективности EEOI и сравнивают его с конструктивным индексом энергоэффективности EEDI для новых судов. Индексы имеют одинаковый физический смысл - отношение произведенного за рейс (рейсы) $\mathrm{CO}_{2}$ к величине транспортной работы судна за определенный период:

$$
\mathrm{EEOI}=\left(\mathrm{MTЭP}_{\phi} \times \mathrm{CF}\right) / \mathrm{Aф},
$$

где МТЭРф - фактическое потребление топлива в эксплуатации всеми потребителями, $\mathrm{T}$

$\mathrm{A}_{\phi}-$ действительная транспортная работа судна в т х миль;

$\mathrm{CF}$ - безразмерный коэффициент перевода расхода топлива к выбросам $\mathrm{CO}_{2}$.

Разумеется, наибольший интерес для судоходства, представляет вопрос определения факторов влияющих на изменение эксплуатационного индекса энергоэффективности.

Для определения основных эксплуатационных параметров влияющих на эксплуатационный индекс энергоэффективности нами были проведены натурные эксперименты на транстихоокеанском переходе судна типа RO-RO - "GALAXY ACE" валовой вместимостью 59,583 рег.т. Были выявлены операционные меры способные повысить энергоэффективность судна уменьшив выбросы $\mathrm{CO}_{2}$ на морском переходе 
без модификации оборудования (см. рис.1) путем управления транспортной работой и скоростью судна при эффективном планировании рейсов.

Total Fuel consumption and $\mathrm{CO}_{2}$ emissions

\begin{tabular}{|l|r|}
\hline \multicolumn{1}{|c|}{ Parameter } & Value \\
\hline Total fuel consumption & $2322.65 \mathrm{~m}$ tonnes \\
\hline Fuel consumptions assigned to on laden & $7291.9579 \mathrm{~m}$ tonnes \\
\hline Total $\mathrm{CO}_{2}$ emissions & $1940.88 \mathrm{~m}$ tonnes \\
\hline $\mathrm{CO}_{2}$ emissions from all voyages between ports under a MS jurisdiction & $3000.12 \mathrm{~m}$ tonnes \\
\hline $\mathrm{CO}_{2}$ emissions from all voyages which departed from ports under a MS jurisdiction & $2179.92 \mathrm{~m}$ tonnes \\
\hline $\mathrm{CO}_{2}$ emissions from all voyages to ports under a MS jurisdiction & $171.04 \mathrm{~m}$ tonnes \\
\hline $\mathrm{CO}_{2}$ emissions which occurred within ports under a MS jurisdiction at berth & $7120.9178 \mathrm{~m}$ tonnes \\
\hline $\mathrm{CO}_{2}$ emissions assigned to on laden & \\
\hline
\end{tabular}

DISTANCE TRAVELLED, TIME SPENT AT SEA AND TRANSPORT WORK

\begin{tabular}{|l|r|}
\hline \multicolumn{1}{|c|}{ Parameter } & Value \\
\hline Total distance travelled & $23177 \mathrm{n}$ miles \\
\hline Regular navigation & 1554.82 hours \\
\hline Total time spent at sea & 1554.82 hours \\
\hline Regular navigation & 0 hours \\
\hline At anchorage & $96553994 \mathrm{~m}$ tonnes $\cdot \mathrm{n}$ miles \\
\hline Total transport work (mass) & \\
\hline
\end{tabular}

ENERGY EFFICIENCY

\begin{tabular}{|l|c|}
\hline \multicolumn{1}{|c|}{ Parameter } & \\
\hline Fuel consumption per distance & $100.2136 \mathrm{~kg} / \mathrm{n}$ mile \\
\hline Fuel consumption per transport work (mass) & $24.0555 \mathrm{~g} / \mathrm{m}$ tonnes $\cdot \mathrm{n} \mathrm{miles}$ \\
\hline Fuel consumption per distance on laden voyages & Missing source values! $\mathrm{kg} / \mathrm{n}$ mile \\
\hline Fuel consumption per transport work (mass) on laden voyages & $23.5029 \mathrm{~g} / \mathrm{m}$ tonnes $\cdot \mathrm{n} \mathrm{miles}$ \\
\hline $\mathrm{CO}_{2}$ emissions per distance & $314.6204 \mathrm{~kg} \mathrm{CO} / \mathrm{n} \mathrm{mile}$ \\
\hline $\mathrm{CO}_{2}$ emissions per transport work (mass) & $75.5221 \mathrm{~g} \mathrm{CO} / \mathrm{m}$ tonnes $\cdot \mathrm{n}$ miles \\
\hline $\mathrm{CO}_{2}$ emissions per distance on laden voyages & Missing source values! $\mathrm{kg} \mathrm{CO} / \mathrm{n} \mathrm{mile}$ \\
\hline $\mathrm{CO}_{2}$ emissions per transport work (mass) on laden voyages & $73.7506 \mathrm{~g} \mathrm{CO} / \mathrm{m}$ tonnes $\cdot \mathrm{n}$ miles \\
\hline
\end{tabular}

Рисунок 1. Транспортная работа и энергоэффективность судна

Объем потребления топлива на переходе достаточно точно описывался формулой:

$$
\mathrm{Q}=\mathrm{Q}_{\mathrm{T}}\left(\mathrm{V} / \mathrm{V}_{\mathrm{T}}\right)^{3} \text {, }
$$

где: Q-фактическое потребление топлива в т/сут.;

V- эксплуатационная скорость, узл. (см. рис.2);

$\mathrm{Q}_{\mathrm{T}}$ - потребление топлива соответствующее технической скорости в т/сут. ;

$\mathrm{V}_{\mathrm{T}}-$ техническая скорость, узл. 
Из формулы (2) видно, что для судовых дизельных двигателей уровень потребления топлива существенно зависит от скорости. Например, снижение эксплуатационной скорости с 16 до 11 узлов приводит к экономии потребления топлива в сутки на $2 / 3$. При снижении скорости судна, следует учитывать то обстоятельство, что может происходить неполное сгорание топлива и увеличение токсичности отработанных газов. С увеличением нагрузки на главный двигатель и скорости судна, концентрация вредных веществ в отработанных газах снижается. Поэтому, удельное количество отработанных газов, отнесенное к мощности, в основном зависит от режима работы двигателя и его типа и имеет характер гиперболической зависимости.
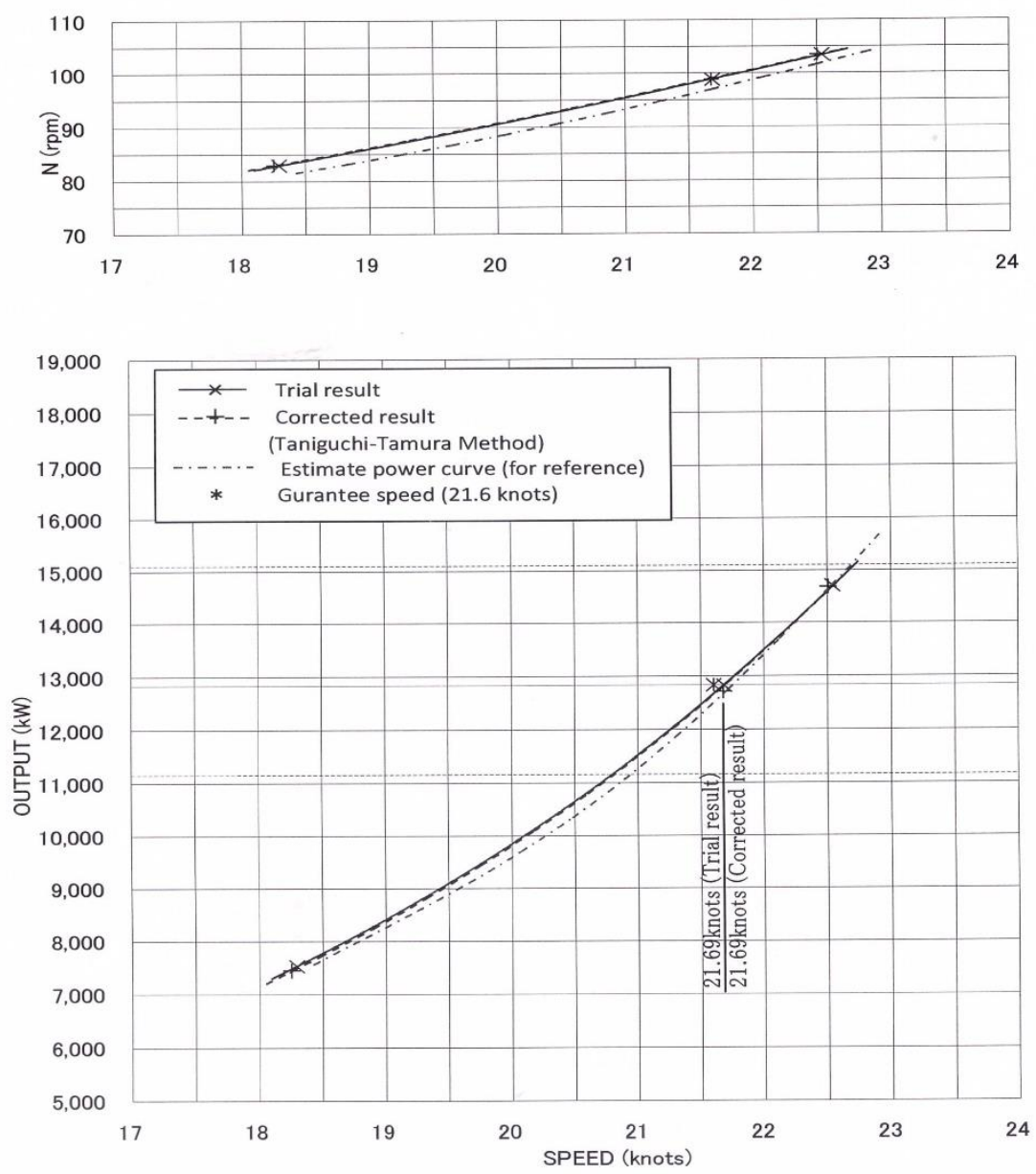

Рисунок 2. Специификационные характеристики судна

Расчеты операционного коэффициента энергетической эффективности судна по формуле (1) показали довольно хорошие результаты, (см. рис.1).

Для целей анализа существенных факторов оказывающих влияние на операционную энергоэффективность морского судна, преобразуем формулу (1) используя понятие материального потока - $\mathrm{M}_{\text {п }}$ (тонн груза в сутки), получим следующее выражение:

где: Т- время рейса в сут.

$$
\mathrm{EEOI}=\mathrm{CF} \times\left[(\mathrm{Q} \times \mathrm{V}) /\left(\mathrm{M}_{\Pi} \mathrm{x} \mathrm{T}\right)\right]
$$

\section{Выводы}

Из (3) видно, что с увеличением дальности пробега и уменьшением скорости энергоэффективность морского судна возрастает. Натурные эксперименты показали, что одним только снижением скорости можно до 34 процентов поднять операционную энергоэффективность морского судна. Подобные решения обычно принимают при перевозке больших партий относительно недорогих массовых грузов (для балкеров и 
танкеров), или при росте цен на судовое бункерное топливо для контейнеровозов, с целью не выводить суда из эксплуатации. Дополнительными факторами улучшающими операционную энергоэффективность морского судна в эксплуатации, могут служить оптимизация маршрута перехода и удеферентовка судна на отход.

$$
* * *
$$

1. Commodities\&Development Report 2019, UNCTAD/DITC/COM/2019/3 [Элек-тронный ресурс]. URL: https://www. un.org/publications (дата обращения 04.06.2021).

2. Пандемия короновируса спасет человеческие жизни [Электронный pecypc]. - URL: https://news.rambler.ru/ecology/43869141 (дата обращения 19.03.2020).

3. Концентрации парниковых газов в атмосфере достигают очередного беспре-цедентно высокого уровня [Электронный ресурс]. - URL: https//meteoinfo.ru/novosti/99-pogoda-v-mire/16592 (дата обращения 03.12.2019).

4. Reviev of Maritime Transport 2020, UNCTAD/RMT/2020 [Электронный pecypc]. - URL: un.org/publications (дата обращения 18.06.2021). 


\title{
SECTION IX. AGRICULTURAL SCIENCES
}

\author{
Куржиев Х.Г. ${ }^{1}$, Апажев А.К. ${ }^{2}$, Шекихачев Ю.А. ${ }^{2}$, Хажметов Л.М. ${ }^{2}$ \\ Исследование влияния гумата+7 «Здоровый урожай» на урожайность \\ сельскохозяйственных культур в условиях Кабардино-Балкарской Республики
}

${ }^{1}$ ФГБУ «Россельхозиентр» по КБР ${ }^{2}$ ФГБОУ ВО Кабардино-Балкарский ГАУ

(Россия, Нальчик)

doi $10.18411 / g q-15-10-2021-15$

\section{Аннотация}

На современном этапе для получения планируемых урожаев все большее значение приобретает оптимизация фитосанитарной обстановки за счет использования достижений современной науки в сочетании с организационными и агротехническими мероприятиями, направленными на минимизацию применения химических средств защиты растений.

Приоритетным направлением в защите растений в последние годы является усиление ее экологизации. Поэтому филиал ФГБУ «Россельхозцентр» по КабардиноБалкарской Республике реализует препарат гумат «Здоровый урожай», производства ООО «АГРОТЕХГУМАТ» Иркутской области, который предназначен для предпосевной обработки семян, корневой и внекорневой подкормок сельскохозяйственных культур.

Для изучения эффективности применения гумата «Здоровый урожай» на различных этапах производства сельскохозяйственных культур: кукурузы, озимой пшеницы, сои, картофеля и огурцов были заложены демонстрационные опыты.

В ходе проведенных опытов установлены: повышение урожайности кукурузы сорта Краснодарский 291 АМВ на 34\% или 19 ц/га; озимой пшеницы сорта Безостая$100 \mathrm{PC}_{1}$ на $16 \%$ или 6 ц/га; сои сорта Вилана на $47 \%$ или $12 ц /$ г; картофеля сортов Кураж и Удача на 8,6 и 8,9 \% или 1,7 и 1,9 т/га соответственно; огурцов сорта ПРОЛИКС на $25 \%$ или 40 ц/га.

По результатам демонстрационных опытов доказано, что при использовании препарата гумат «Здоровый урожай» в баковой смеси с другими препаратами отмечается значительная прибавка урожайности сельскохозяйственных культур в условиях Кабардино-Балкарской Республики.

Ключевые слова: гумат «Здоровый урожай», кукуруза, озимая пшеница, соя, картофель, огурцы, эффективность применения, повышение урожайности.

\section{Abstract}

Nowadays, optimization of the phytosanitary situation using modern scientific achievements in combination with organizational and agrotechnical measures aimed at minimizing the use of chemical plant protection products is becoming increasingly important for obtaining planned crops.

The priority direction in plant protection in recent years is to strengthen its greening. Therefore, the branch of the Federal State Budgetary Institution "Rosselkhozcenter" in the Kabardino-Balkarian republic implements the humate drug "Healthy Crop", produced by OOO AGROTEKHGUMAT of the Irkutsk region, which is intended for the pre-sowing seed treatment, root and top dressing of agricultural crops.

To study the application efficiency of "Healthy Crop" humate at various stages of the production of agricultural crops: corn, winter wheat, soybeans, potato, and cucumbers, demonstration experiments have been carried out. 
During the experiments, the following yield increase indicators were observed: corn of Krasnodarskiy 291 AMV variety - by $34 \%$ or $19 \mathrm{dt} / \mathrm{ha}$; winter wheat of Bezostaya-100 $\mathrm{RS}_{1}$ variety - by $16 \%$, or $6 \mathrm{dt} / \mathrm{ha}$; soybeans of Vilana variety - by $47 \%$ or $12 \mathrm{dt} / \mathrm{ha}$; potato of Kurazh and Udacha varieties - by 8.6 and $8.9 \%$ or 1.7 and $1.9 \mathrm{dt} /$ ha respectively; cucumber of PROLIKS variety - by $25 \%$ or $40 \mathrm{dt} / \mathrm{ha}$.

According to the results of demonstration experiments, it was proved that when using "Healthy Crop" humate in a tank mixture with other drugs, a significant yield increase of agricultural crops in the conditions of the Kabardino-Balkarian republic was observed.

Keywords: humate "Healthy Crop", corn, winter wheat, soybeans, potato, cucumbers, application efficiency, yield increase.

Введение. На современном этапе для получения планируемых урожаев все большее значение приобретает оптимизация фитосанитарной обстановки за счет использования достижений современной науки в сочетании с организационными и агротехническими мероприятиями, направленными на минимизацию применения химических средств защиты растений [1].

Приоритетным направлением в защите растений в последние годы является усиление ее экологизации. Поэтому филиал ФГБУ «Россельхозцентр» по КабардиноБалкарской Республике реализует препарат гумат «Здоровый урожай», производства ООО «АГРОТЕХГУМАТ» ИркУТской области.

Гумат «Здоровый урожай», предназначен для предпосевной обработки семян, корневой и внекорневой подкормок сельскохозяйственных культур. Массовая доля питательных веществ, содержащих в биопрепарате составляет: смесь калиевых и/или натриевых солей гуминовых кислот - 3,7\%, К- 0,5\%, Мо - 0,0018\%, В - 0,02\%, Fe $0,02 \%, \mathrm{Mn}-0,01 \%, \mathrm{Zn}-0,02 \%, \mathrm{Cu}-0,02 \%, \mathrm{Co}-0,002 \%$, что обеспечивает получение стабильной прибавки урожая сельскохозяйственных культур [1-3].

Материал и методика исследования. Предпосевная обработка семян, которые использовались для проведения опытов, обрабатывались полусухим методом водным раствором гумат «Здоровый урожай» в дозе от 50...180 гр. на 10 литров раствора на I т семян совместно с протравителями типа Дивиденд, Оплот, ВСК.

В 2020 году был заложен демонстрационный опыт по схеме «опыт-контроль» по испытанию средств защиты растений (гумат «Здоровый урожай») на кукурузе сорта Краснодарский 291 АМВ на площади 8 га, где один гектар возделывался по традиционной технологии (контроль) на поле КФХ «Кочесоков А.Э.» с.п. Псычох.

Проведена предпосевная культивация 27 апреля. Предшественник - озимый ячмень.

Посев провели 28 апреля 2020 года с внесением минеральных удобрений (нитроаммофоска 16:16:16 с нормой расхода 100 кг/га). Норма высева 68 тыс. зерен/га. Расход семян - 23 кг/га.

Всходы появились 10 мая. Густота стояния - 63-65 тыс. растений/га.

28 мая 2020 г в фазе 3-5 лист проведена первая гербицидная обработка, баковой смесью: Приоритет, КС - 1,3 л/га + Пришанс, СЭ - 0,5 л/га + гумат «Здоровый урожай» 1,2 л/га.

Спустя 2 недели после химической прополки проводилась междурядная культивация, через 2-3 дня после культивации в период фазы развития 7-8 листа провели вторую обработку баковой смесью гумат «Здоровый урожай» - 1,2 л/га + Ризоплан, Ж - 2,0 л/га.

В виду того, что отмечалась засуха, проводилась третья обработка баковой смесью гумат «Здоровый урожай» - 1,2 л/га + Ризоплан, Ж - 2,0 л/га + Цинко-магниевая смесь.

В хозяйстве ООО «Зольский Картофель» были заложены опыты по изучению влияния гумата «Здоровый урожай» на посевы картофеля. 
Участки были расположены на одной клетке, в одинаковых условиях в с.п. Белокаменское. Предшественник кукуруза.

Сев на опытном участке проходил 3 мая.

Было посажено 2 ряда (по одному мешку на ряд) сорта «Удача» и два ряда сорта «Кураж» (по одному мешку на ряд). Картофель возделывался согласно традиционной технологии, но по одному ряду каждого сорта были проведены дополнительные обработки по листу, с использованием гумата «Здоровый урожай».

В период вегетации листовая подкормка картофеля на опытных рядах гуматом «Здоровый урожай» проводилась дважды.

25 июня в фазе бутонизации была проведена первая листовая подкормка препаратами гумат «Здоровый урожай» -1,0 л/га + Эпин Экстра, Р - 80 мл/га.

20 июля была проведена вторая инсектицидная обработка Борей Нео, СК - 0,15 л/га + гумат «Здоровый урожай» - 1,0 л/га.

В период гербицидной обработки против двудольных и однодольных сорняков соя испытывает тяжелый стресс, с которым она может справиться только на 10-12 день. Это приводит к потере урожая. Применение гумата «Здоровый урожай» в этот период способен снизить негативное влияние на растения. Чтобы в этом убедиться был заложен демонстрационный опыт в Лескенском районе по влиянию гумата «Здоровый урожай» на посевах сои сорта Вилана в период химической прополки.

Место расположения: с. п. Анзорей, участок арендатора Тоховой М.М., на площади - 3 га.

Опыт заложен в трех вариантах: Контроль - обычная технология с применением гербицида Фабиан, ВДГ норма расхода 0,1 л/га; Вариант 1 гербицид Фабиан, ВДГ - 0,1 л/га + гумат «Здоровый урожай» - 1,5 л/га и биопрепарата Ризоплан, Ж с нормой расхода 2,0 л/га; Вариант 2 - Фабиан, ВДГ - 0,1 л/га + Мегафол - 1,5 л/га.

Производственный опыт по изучению влияния гумата «Здоровый урожай» на урожайность озимой пшеницы сорта Безостая-100 $\mathrm{PC}_{1}$ был заложен на площади 20 га (арендатор Хуштов Х.3.).

Почва - обыкновенный чернозем. Повторность опыта трехкратная, площадь делянок 100 м² $^{2}$ пшеницу высеяли в начале октября, норма высева 200 кг/га.

Исследования проводились на двух уровнях - контроль (без применения удобрений) и с применением гумата «Здоровый урожай» в фазы кущения и колошения.

Предшественник на озимой пшенице - озимая пшеница. Состояние озимой пшеницы удовлетворительное.

14 апреля проводили опрыскивание посевов гербицидом Прима, СЭ - 0,6 л/га + Банвел, ВР - 0,3 л/га с добавлением гумата «Здоровый урожай» -1,0 л/га.

15 мая была проведена вторая химическая обработка препаратами Колосаль, КЭ - 1,0 л/га + гумат «Здоровый урожай» 1,0 л/га.

Урванским райотделом филиала ФГБУ «Россельхозцентр» по КБР в 2020 году заложен демонстрационный опыт по испытанию гумата «Здоровый урожай» на огурцах сорта «ПРОЛИКС» на площади 14 га в с.п. Ст. Черек на поле ИП Альборова А.М.

Посев провели 15 мая 2020 года. Густота - 40 тыс. растений на 1 га.

Всходы появились 22 мая.

Первая обработка баковой смесью была проведена 6 июня, в период цветения Абига Пик, ВС - 3,0 л/га + Искра, СП - 1,0 кг/га + Гумат «Здоровый урожай» - 0,8 л/га.

Вторая обработка баковой смесью была проведена в период формирования плода Квадрис, СК - 0,6 л/га + Инфинито, КС - 1,4 л/га + Гумат «Здоровый урожай» 0,8 л/га.

Результаты и обсуждение. В результате изучения влияния гумата «Здоровый урожай» на рост и урожайность кукурузы сорта Краснодарский 291 AMB было установлено, что в период вегетации ширина листовой пластины в опытном образце была больше (рис.1, а), чем на контроле (рис. 2, б). 

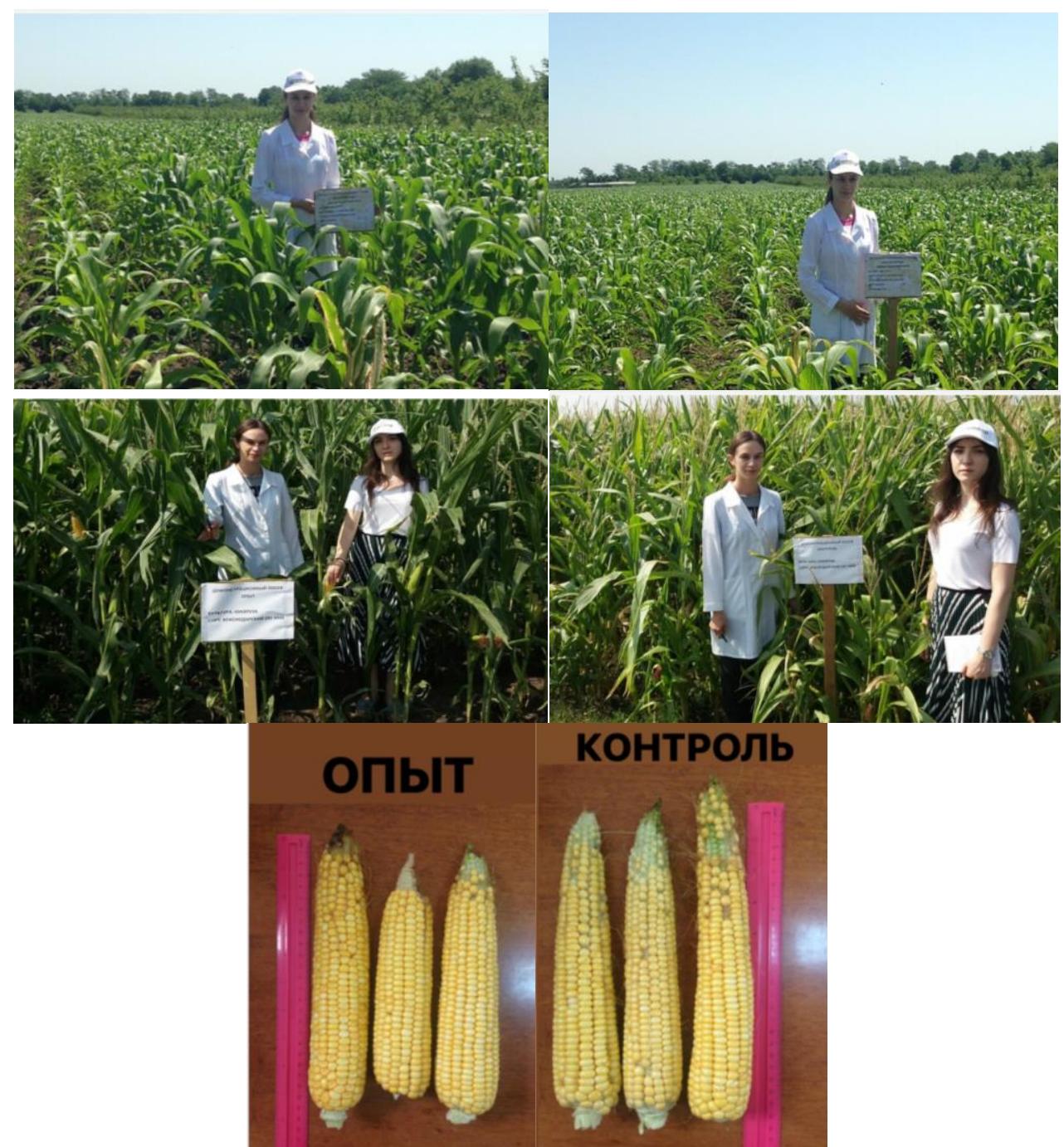

a.

$\sigma$.

Рисунок 1. Влияние гумата «Здоровый урожай» на развитие и урожайность кукурузы сорта Краснодарский 291 АМВ на опытном (а) и контрольном (б) участках

Высота кукурузы на опытном участке были значительно выше, а размеры початков кукурузы преобладали над контрольными. Урожайность кукурузы на опытном участке с применением гумата «Здоровый урожай» составила 75 ц/га, а на контрольном участке - 56 ц/га. Прибавка урожая составила 19 ц/га или 34\%.

В результате проведенных опытов по изучению влияния гумата «Здоровый урожай» на урожайность картофеля сортов «Кураж» и «Удача» установлено, что гумат «Здоровый урожай» положительно влияет на рост, развитие и урожайность картофеля (табл.1).

Таблийа 1

Влияние гумата «Здоровый урожай» на урожайность картофеля сортов «Кураж» и

\begin{tabular}{|c|c|c|c|c|}
\hline \multirow[t]{2}{*}{ Copm } & \multirow[t]{2}{*}{ Урожайность, m/га } & \multirow{2}{*}{$\begin{array}{c}\text { Масса товарных } \\
\text { плодов в среднем, гр. }\end{array}$} & \multicolumn{2}{|c|}{$\begin{array}{c}\text { Прибавка к } \\
\text { урожайности }\end{array}$} \\
\hline & & & $m / 2 a$ & $\%$ \\
\hline $\begin{array}{l}\text { «Кураж» } \\
\text { (контроль) }\end{array}$ & 19,7 & 98,4 & - & - \\
\hline «Кураж» (опьыт) & 21,4 & 103,6 & 1,7 & 8,6 \\
\hline $\begin{array}{c}\text { «Удача» } \\
\text { (контроль) }\end{array}$ & 20,1 & 99,7 & - & - \\
\hline «Удача» (onblm) & 21,9 & 104,4 & 1,8 & 8,9 \\
\hline
\end{tabular}


В период гербицидной обработки посевов сои против двудольных и однодольных сорняков было установлено, что на контрольном учатке наблюдалось остановка роста основной культуры и усиливалась восприимчивость к болезням из-за стресса от внесенного гербицида, урожайность сои составила 25 ц/га.

На первом варианте наблюдалась способность к повышению иммунитета, в совокупности со стимулирующим эффектом, урожайность составила 37 ц/га.

На втором варианте отмечалось развитие и поражение болезнями, такими как аскохитоз, бактериоз несмотря на использование антистресса Мегафол. Урожайность сои составила 32 ц/га.

В целом наблюдалось стрессовое воздействие гербицида, последствие которого привело к снижению урожая на 33 \%.

Однако совместное внесение гумата «Здоровый урожай» с гербицидами позволило увеличить рентабельность производства сои на 147 \% по сравнению с обычной технологией (контроль).

Общее состояние посевов озимой пшеницы сорта Безостая-100 $\mathrm{PC}_{1}$ показано на рисунке 2.

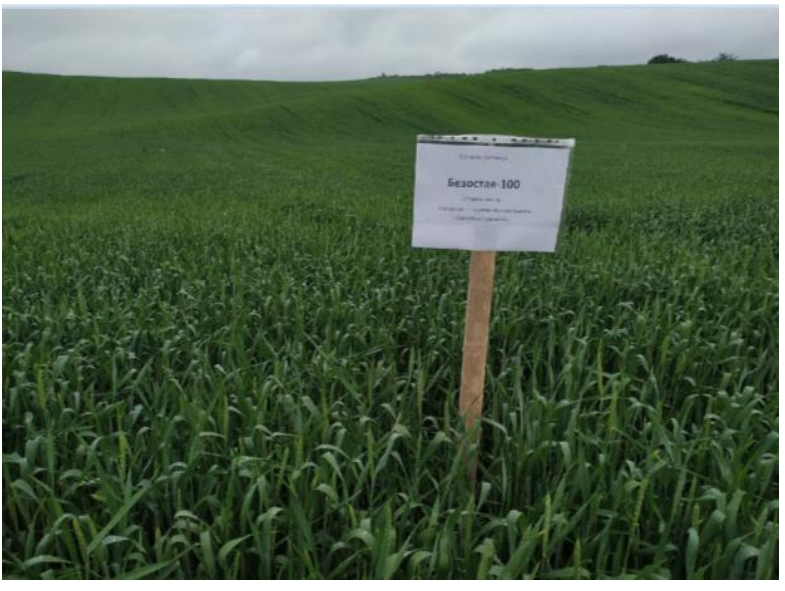

$a$

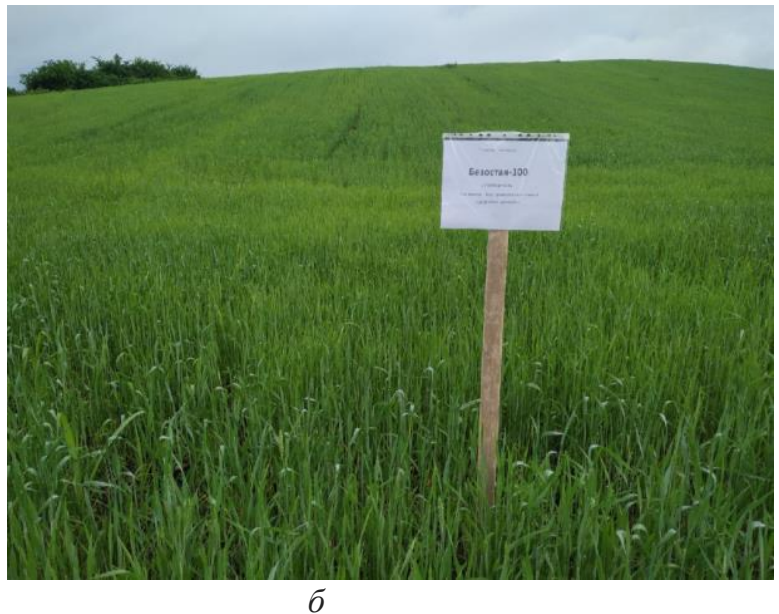

б

Рисунок 2. Общее состояние посевов озимой пшеницы сорта Безостая-100 на опытном (a) $u$ контрольном (б) участках

Применение гумата на посевах озимой пшеницы способствовало снижению заражения грибковыми заболеваниями, что обеспечило прибавку урожая. Урожайность на участке с применением гумата «Здоровый урожай» составила 42,5 ц/га, что на 6,0 ц/га выше по сравнению с контролем.

Урожайность огурцов на опытном участке с применением гумата «Здоровый урожай» составила 200 ц/га, что на 25 \% больше чем на контрольном участке. При этом продолжительность плодоношения увеличилась на 1,5-2 недели.

По результатам демонстрационного опыта видно, что при использовании гумата «Здоровый урожай» в баковой смеси с другими препаратами отмечается значительная прибавка урожайности.

\section{Заключение.}

1. В ходе проведенных опытов установлены: повышение урожайности кукурузы сорта Краснодарский $291 \mathrm{AMB}$ на 34\% или 19 ц/га; озимой пшеницы сорта Безостая-100 $\mathrm{PC}_{1}$ на 16\% или 6 ц/га; сои сорта Вилана на 47\% или $12 ц /$ га; картофеля сортов Кураж и Удача на 8,6 и 8,9 \% или 1,7 и 1,9 т/га соответственно; огурцов сорта ПРОЛИКС на 25\% или 40 ц/га.

2. При использовании препарата гумат «Здоровый урожай» в баковой смеси с другими препаратами отмечается значительная прибавка 
урожайности сельскохозяйственных культур в условиях КабардиноБалкарской Республики.

$$
\text { *** }
$$

1. Обзор фитосанитарного состояния посевов сельскохозяйственных культур в 2020 году и прогноз на 2021 год / Х.Г. Куржиев, З.А. Бегидова, А.Р. Курманов, Ж.Л. Кокова, А.В. Власенко, А.А. Гучаева. - Нальчик: «Полиграфия», 2021. - 161с.

2. Комплекс технологий и технических средств возделывания сельскохозяйственных культур в системе органического земледелия с использованием инновационных биологических систем защиты, методов мелиорации и экологизации / А.К. Апажев, Ю.А. Шекихачев, Л.М. Хажметов, Х.Г. Куржиев, А.М. Егожев, А.Л. Хажметова. - Нальчик: КБГАУ, 2020. - 219 с.

3. Шекихачев, Ю.А. Протравливание озимых культур / Ю.А. Шекихачев, Л.М. Хажметов, Л.З. Шекихачева, Х.Г. Куржиев // Фермер. Поволжье. - 2020. - №3. - С. 50-53. 


\section{SECTION X. ECONOMY}

\section{Мамадаезова А.A. \\ Рынок труда и конкурентоспособность молодых женщин ГБАО}

Академия гуманитарных наук им Б. Искандарова

(Таджикистан, Хорог)

doi $10.18411 / g q-15-10-2021-16$

\section{Аннотация}

В данной статье представлены определение конкурентоспособности рынка труда, конкурентоспособности молодежного рынка труда ГБАО которое охватывает сегмент женщины в возрасте от 19 до 30 лет обучающихся и закончившие Вуза в ГБАО.

Ключевые слова: конкурентоспособность, безработица, рынок труда, сегментация рынка, конкуренция, профессионализм, специалист.

\section{Abstract}

This article presents the definition of the competitiveness of the labor market, the competitiveness of the youth labor market of GBAO, which covers the segment of women aged 19 to 30, students and graduates of the University in GBAO.

Keywords: competitiveness, unemployment, labor market, market segmentation, competition, professionalism, specialist.

В современном понятии рынок труда представляет собой система общественных отношений с интересами работодателей и наемных рабочих сил. По мнению А.И. Рофе: «Рынок труда - это составная часть структуры рыночной экономики, которая функционирует в ней наряду с другими рынками: сырья, материалов, товаров народного потребления, услуг, жилья, ценных бумаг и др.» [16]. Точнее говоря, рынок труда - это система общественных отношений, связанных с наймом и предложением рабочей силы, или с ее куплей, продажей (ценой рабочей силы является зарплата). По определению Н.А. Волгина: «Рынок труда - совокупность социально-трудовых отношений между покупателями и продавцами по поводу условий найма и использования рабочей силы» [20].

Перечисленные определения и понятия рынка труда не ограничены и по нашему мнению рынок труда в образование определяет предложением со стороны высших учебных заведений рынку труда.

Рынок труда тоже является одним из сегментов рынка и английский экономист Г. Стэндинг выделяет пять сегментов рынка труда:

- рынок специалистов наиболее высокой квалификации;

- рынок квалифицированных кадров;

— от роста цен);

- рынок труда малоквалифицированных работников (предложение, как правило, всегда превышает спрос);

- остаточный рынок труда (безработные, женщины, молодежь).

На основе вышесказанного, рынок труда действительно работает под такими сегментами которое каждый специалист проявляет свои компетенции и личностные качества.

Исходя из мнения Г. Стендинг мы с уверенностью можем сказать, что в РТ тоже такой сегмент рынок ведет действие и на данный момент современный рынок труда переходного периода формируется под воздействиям таких высшее 
перечисленных сегментов труда. Для этого возникает вопрос о конкурентоспособности рынка труда. Под конкурентоспособностью рынка труда мы понимаем человека проявляющие себя на рынке труда своим профессиональными компетенциями и оплата труда которое он готов получит.

По статистическим данным население ГБАО составляет 228,5 тыс. К разряду объективных факторов относятся отставание женщин от мужчин в уровне профессиональной подготовки и квалификации.

Из факторов субъективного характера наиболее значимым является то, что молодые женщины от возраста 19 до 30 лет психологически не готовы к конкуренции за рабочие места, поскольку привыкли к защищенности сфере труда даже если она не связанно с профессиональными качествами. В дальних регионах также мало встречается конкуренция среди молодых женщин на сегмент высокой квалификации, квалифицированных кадров и рынка труда рабочих профессий. Так как дополнительных рабочих мест отсутствует в горных регионах. В ГБАО Хорогский государственный университет является единственным источником по предоставление высшее образование. Общее количество студентов составляет 3822, из которых 1979 молодые женщины и 1843 мужчины, Вуз каждый год выпускает до 500 выпускников. Принципиальным отличием рынка труда молодых женщин от молодёжь является качественные особенности рабочей силы, что в свою очередь характеризует уровень их конкурентоспособности. После окончания Вуза молодые владеют недостатком профессиональных знаний и отсутствует необходимой квалификации и трудовых навыков. При этом для работодателям труд молодых оказывается невостребованным так как не имея опыта работы. Только окончившие Вуз желают устроится на высокооплачиваемую работу. В итоге происходит несовпадение ожидание от действительности. По проведению нами исследование на рынке образовательных услуг встречаются безработные среди женщины молодёжь которое закончили Вуз с красным дипломом и имеют степень магистра. Мы проводили мини исследование в г. Хороге по востребованости молодых женщин от 19 до 30 лет к работе и их конкурентоспособность на рынке труда. Исследование проводилось по методу анкетного опроса выборка респондентов была случайной. В основном в опросе принимали участие респонденты студенты и выпускники экономического факультета.

Данный опрос состоял из 12 вопросов. Всего от возраста 18 до 30 лет ответили 35 респондентов. 100 процентов являются студентами и выпускники Хорогского государственного университета. Место проживания г. Хорог. Для устройство на работу работодатели требуют в наличие диплома и поэтому было заданно вопрос где вы будите работать после получения диплома? Ответ был таковым, 37,5\% отметили да, $62,5 \%$ нет. По данным ответам можно сказать, что 37,5\% уверенны в своем знание и могут найти работу самостоятельно и конкурировать на рынке труда с другими, а $62,5 \%$ твердят обратное. Выпускники после окончания Вуза не уверенны в какой сфере они будут работать. Получили такие результаты: см на диаграмму 1

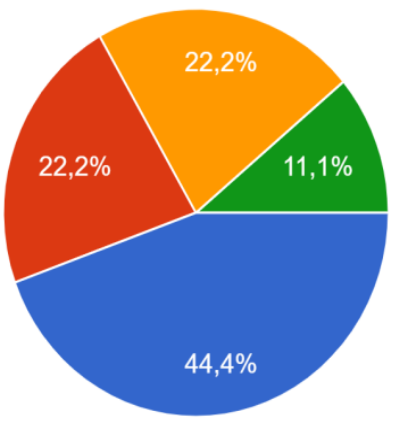

по специальностей

В сфере образования

продолжу учится

Вариант 4

Диаграмма 1. Сфера работы выпускников 
Данная диаграмма показывает, что 50\% выбирают по специальности, 12,5\% в образование, 25 \% продолжать учиться, и лишь 12,5\% выбирают вариант 4 другую работу.

На вопрос следующий работали ли вы во время учебы? 100 процентов респонденты подчеркивали нет. Этим можно сделать вывод, что в ГБАО практически для студентов отсутствует рабочее место. Выпускники после получение диплома в поиске работы откуда студентам найти работу. При этом возникает вопрос легко ли трудоустроится на работу См на диаграмму 2.

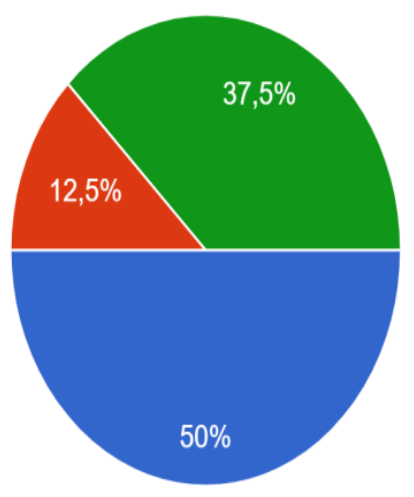

отсутствие опыта

не умение презентировать себя работодателю

теоретический характер знаний

невостребованная профессия на рынке труда

Диаграмма 2. Препятствия для трудоустройства

Данные показывают что $57 \%$ в отсутствует опыт работы, 28,6\% не востребованная профессия рынку труда, и 14,3\% не могут презентовать себя во время собеседования. Можно сказать, что не каждый студент может совмещать учебу и работу но было бы положительным результатом о трудоустройстве во время учебного процесса. При выходе на первичный рынок труда студенты и выпускники в ожидание от 900 до 1200 которое составляет 50\%, 37,5\% в ожидание от 1300 до 1600 и лишь 12,5 \% на 600 до 800 получать хотя бы такой размер заработной платы. См на диаграмме 3.

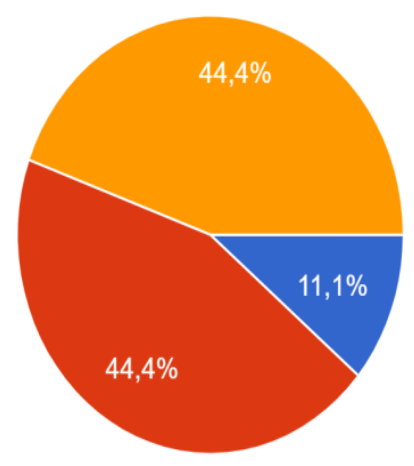

500-800 сомони

900-1200 сомони

1300-1600 сомони

Диаграмма 3. Ожидание респондентов 3П

Роль конкуренция в рынке труда велика, найти желаемое место трудно студентом и выпускникам Вузов. 55\% опрошенные считают, что главное в трудоустройстве играет личные качество, $33 \%$ наличие знание и квалификации студентов, $11 \%$ родители, родственники и друзья помогают устроится на работу. См на диаграмму 4 


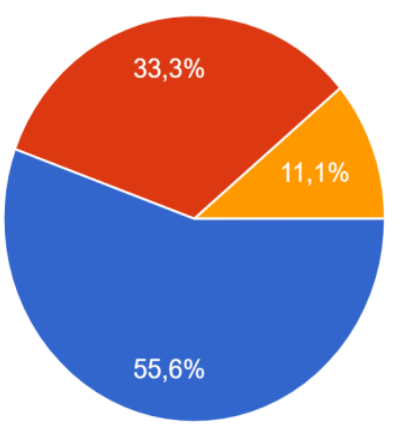

личные качество

наличие знаний

родители

другое

Диаграмма 4. Качество ожидание при принятие на работу

По мнению молодых в настоящие время очень трудно найти работу в горных регионах и большинство работодатели предпочитают принимать на работу с опытом работы а у выпускников и студентов опыт работы отсутствует. Из за нехватки рабочих месть большинство молодежь являются безработными. По мнению опрошенных причина молодёжной безработицы в ГБАО подчеркивали следующие:

- отсутствие рабочих мест;

- отсутствие практических знаний;

- отсутствие производство в ГБАО;

- отсутствие цели при выбранной профессии.

После подчеркивание причины безработицы в ГБАО респонденты все таки считают, что их специальность является конкурентоспособным на рынке труда ГБАО. Но рынок все таки ведет свои изменения в систему взаимоотношения в сфере образования и производства при этом требует новые требования, новые специальности которые может заинтересовывать в получение образования на уровне мирового стандарта. Поэтому рынок предъявляет следующие: профессиональное образование; к личности; к производстве.

По проведенному исследования нами было предложено рекомендации и предложения. Женщины не готовы конкурировать на рынке по сравнению с мужчины, выбор профессии является правильным решениям устроится в будущем и найти себя на рынке труда(профориентация), отсутствие конкурентоспособность студентов на рынке труда ГБАО, рынок труда должна способствовать по специальностями студентов женского пола, отсутствие рабочих мест выпускникам в государственных учреждениях, отсутствие поддержки выпускникам для ведения бизнеса.

$$
* * *
$$

1. Е. Груздва, Л. Ржаницына, 3.Хоткина Женщина на рынке труда // женщина и общество

2. Кот. В. В, Кузмына.А.Г Молодёжный сегмент труда: специфика, мониторинг, основные направления регулирования

3. Н. В. Корнейченко Астраханский государственный политехнический колледж Конкурентоспособность будущего специалиста как показатель личного качества подготовки //Вестник АГТУ 2007

4. Опрышко Юлия Игоревна, Баранникова Мария Александровна, Арутюнян Сона Атомовна, Гончарова Светлана Николаевна Рубрика: Экономика и управление. // Молодой учёный №30 (134) 2016.

5. www.studref.com Сегментация рынка труда - экономика труда. 


\section{SECTION XI. CULTUROLOGY}

\section{Бочков П.В. \\ История возникновения и деятельности общины священника Александра Кожевникова в Республике Коми}

Межрегиональная академия управлением персонала (Украина, Киев)

doi $10.18411 / g q-15-10-2021-17$

\section{Аннотация}

Статья посвящена истории возникновения и деятельности околоправославной религиозной группы под руководством бывшего клирика Русской Православной Церкви священника Александра Кожевникова. Псевдоправославная апокалиптика и особое псевдодуховное состояние, заставившее последователей Кожевникова удалиться от общества, привели членов группу к сектантскому вырождению и очевидному социальному и духовному регрессу.

Ключевые слова: псевдоправославие, сектантство, Александр Кожевников, неканоническое православие, социальный изоляционизм.

\section{Abstract}

The article is devoted to the history of the emergence and activities of a near-Orthodox religious group under the leadership of the former cleric of the Russian Orthodox Church, priest Alexander Kozhevnikov. Pseudo-Orthodox apocalypticism and a special pseudospiritual state that forced Kozhevnikov's followers to withdraw from society, led the members of the group to sectarian degeneration and obvious social and spiritual regression.

Keywords: pseudo-Orthodoxy, sectarianism, Alexander Kozhevnikov, non-canonical Orthodoxy, social isolationism.

В эпоху социальных потрясений и преобразований в политической сфере, затрагивающих, как правило, вопросы государственного устройства и ценностных ориентиров общества, не редки обращения к духовной жизни, углублению отдельных лиц в религиозную практику. Возрождение церковной жизни в конце XX века в России побудило приход в нее массу совершенно разных людей, и некоторые из них не всегда адекватно воспринимали духовные традиции и каноническое устройство Православной Церкви. Религиозная экзальтация, критика церковной иерархии, социальный изоляционизм и религиозный психоз в сочетании с фанатичным религиозным сознанием способны создать нездоровую религиозную общину и в лоне традиционной религиозной конфессии.

Группа верующих, помраченных апокалиптической истерией, в начале 2000-х гг. объединилась вокруг священника Александра Кожевников из г. Уржума Вятской епархии Русской Православной Церкви. В Вятской епархии священник Александр прослужил много лет, однако епархиальное руководство, по его мнению, недооценивало его, что подвигло о. Александра на выход за штат епархии в 2003 г. [2]. Ранее свящ. Александр ошибочно был упомянут под фамилией Коврижных, вследствие чего в ряд публикаций о нем вкралась неточность по части указания его фамилии [1; с. $342-345]$.

Своих прихожан священник призвал к отказу «от новых паспортов, ИНН, заявил о скором конце Света, после чего собрал своих последователей (называются различные цифры - от 48 до 80 человек) и уехал спасаться от власти антихриста в окрестности поселка Обдыр [в других источниках - Обдор - прим. автора] (Коми), большинство 
уехавших вместе с о. Александром при отъезде распродали все свое имущество и квартиры» [4].

В 2003 г. Александр Кожевников во главе большой группы верующих прибыл в Республику Коми. Группа «... с согласия местной власти обосновалась в Княжпогостком районе для ведения общинной жизни: им была выделена заброшенная ферма в нескольких километрах от села Мещура» [7]. Ранее это место называлось поселком Обдор, который, как и десятки тысяч населенных пунктов, прекратил свое существование к 1991 г. В 2006 г. поселение свящ. Александра Кожевникова, к тому времени уже находившемуся под запрещением, покинула часть верующих, однако к ноябрю 2009 г., в его общине насчитывалось не менее 35 человек. Одним из покинувших Кожевникова являлся и диакон Владислав, который после принесения покаяния воссоединился с Русской Православной Церковью и в 2013 г. был рукоположен в сан священника.

Первоначально священник Александр не планировал уклонения в раскол и даже подал прошение о приеме в клир Сыктывкарской епархии, однако принят не был и стал действовать самостоятельно. Позже, реагируя на неканонический характер общины, епархиальное руководство попыталось наладить контакт с общиной, однако из этого ничего так и не вышло.

«Дважды епископ Сыктывкарской и Воркутинской епархии Питирим, а также секретарь епархии игумен Филипп посещали эту общину с увещеваниями о необходимости возвращения к нормальной жизни. Общине отправлялись неоднократные письменные призывы к отказу от их религиозных заблуждений. Но все эти попытки не имели успеха.

Также отрицательно сектанты реагировали и на приезды местных представителей власти, милиции. «Если раньше члены этой общины выходили в соседние населенные пункты, общались с местными жителями и фактов о насильственном удерживании людей в общине не было, то в последний год община становилась все более закрытой, ее члены практически разорвали свои связи с внешним миром, живут на заброшенной ферме, куда нет дороги, без электричества и связи, ведут натуральное хозяйство», - рассказал собеседник...

О фактах насильственного удерживания рассказала молодая девушка, которой удалось сбежать из общины, она уже направила письменное заявление в прокуратуру и МВД. Со своей стороны, Сыктывкарская и Воркутинская епархия направила заявление в Министерство внутренних дел по Коми, Министерство образования Р[еспублики] К[оми] и Министерство здравоохранения Р[еспублики] К[оми], прокуратуру для принятия мер и выяснения причин насильственного удерживания лиц, прибывших из Кировской области» [7]. Заявления о насильственном удержании людей в общине были преувеличены [6], и в результате проверок правоохранительными органами не подтвердились, однако группа последователей Александра становилась все меньше.

Обжившись на новом месте, общинники построили деревянный храм, в котором стали совершать регулярные богослужения. При этом священник Александр Кожевников на Божественной литургии поминал Патриарха Московского и всея Руси «с добавкой "аще не еретик - помяни Господи"» [4]. В своей общине Кожевников вошел в образ «духовного старца», борца с экуменизмом и глобализацией, у которого в безусловном послушании должны были находиться все последователи [5].

Жизнь в общине была полна тягот и невзгод, особенно связанных с отсутствием медицинского обеспечения и продовольствия, в результате, «к февралю 2013 кроме священника в общине остался только один мужчина» [4].

В марте 2014 г. в Обдоре «на месте сгоревшего дома были обнаружены несколько человеческих скелетов (по разным данным, от двух до десяти)». Что явилось причиной пожара и массовой гибели людей - этим занимались сотрудники внутренних органов, однако результаты экспертиз не известны. 
Архиепископ Сыктывкарский и Воркутинский Питирим (Волочков) «заявил, что, вполне вероятно, уржумские отшельники в поселке Обдор могли покончить жизнь самосожжением. В Уржумской епархии считают, что оставшиеся в живых сектанты могли уйти дальше в леса. По типу религиозности секта Александра Кожевникова напоминала секту "сидельцев" Петра Кузнецова в Пензенской области, члены которой год ждали конца света в подземелье» [3]. С этого времени ничего не известно ни о священнике Александре Кожевникове, ни о его последователях, что, конечно, не исключает возможности, что небольшая община его последователей продолжает существовать на территории Республики Коми.

Печальные явления, направленные на отрыв от семьи и общества, и в наш век развития информационных технологий способны явить физические и психические страдания, которые, в свою очередь, могут окончиться и трагедией. С сожалением отмечая подобные явления в нашей современной жизни, все же необходимо констатировать и тот факт, что подобных околоправославных и сектантских групп в настоящее время весьма немного. Становится понятно, что лишь каноническое сознание и воспитание будущих священнослужителей в рамках духовных школ, усвоение системных знаний о православной вере, ее догматики и канонах способны обеспечить здоровое духовное руководство в православных общинах.

$$
\text { *** }
$$

1. Бочков Павел, свящ. Обзор неканонических православных юрисдикций XX-XXI вв. Т. 5: Дисциплинарно-психологические расколы: монография / свящ. П.В. Бочков. - СПб.: Свое издательство, 2020. -523 с. С. $342-345$.

2. Елькина Вера. Заложники веры // Newsler.ru - Информационный портал Кирова [Электронный pecypc]. - 2021. - Режим доступа: https://www.newsler.ru/society/2009/11/12/zvera - Дата доступа: 07.09.2021.

3. Лушникова Екатерина. В лесах Коми найдены останки членов Вятской религиозной секты // Радио Свобода [Электронный pecypc]. - 2021. - Режим доступа: https://www.svoboda.org/a/25320799.html - Дата доступа: 07.09.2021.

4. Малые эсхатологические православные группы // Иерархия литургических церквей [Электронный pecypc]. - 2021. - Режим доступа: http://www.hierarchy.religare.ru/h-orthod-malesch.html - Дата доступа: 07.09.2021.

5. Пластинин Владислав. Рассказы отшельников из Обдыра // Сыктывкарская и Воркутинская епархия [Электронный ресурс]. - 2021. - Режим доступа: http://syktyvkar.eparchia.ru/12news2013/20131217.html - Дата доступа: 07.09.2021.

6. Радова Арина. Вятский священник не верит в насильственное удержание кировчан в религиозной общине // Newsler.ru - Информационный портал Кирова [Электронный ресурс]. - 2020. - Режим доступа: https://www.newsler.ru/incidents/2009/1 1/06/kogevnikov - Дата доступа: 30.04.2020.

7. Репина Ольга. В религиозной общине в Коми насильно удерживают людей // ИА Комиинформ [Электронный ресурс]. - 2020. - Режим доступа: https://komiinform.ru/news/60124/ - Дата доступа: 12.05.2020. 


\title{
SECTION XII. JURISPRUDENCE
}

\author{
Медведев В.Г. \\ Деятельность белых правительств в налоговой сфере на севере и северо-западе \\ России в годы Гражданской войны
}

Тольяттинский государственный университет

(Россия, Тольятти)

doi $10.18411 / g q-15-10-2021-18$

\section{Аннотация}

В статье исследуется малоизученная в отечественной историко-правовой науке проблема деятельности антисоветских правительств Севера и Северо-Запада России в налоговой сфере в годы гражданской войны. Выявлено, что налоговое законодательство и административная практика государственных органов основывалось на дореволюционном законодательстве и в русле налоговой политики Российского правительства адмирала А.В. Колчака. Определено, что поступления в бюджет от прямых налогов составляли ничтожные суммы. Косвенные налоги ввиду чрезвычайно слабого развития промышленности и торговли и отсутствия необходимых товаров и услуг практически не собирались. Установлено, что северо-западном государственном образовании по причине кратковременности его существования и незначительной территории, а также неразвитости предпринимательства налоги заменялись реквизициями, проводившимися воинскими начальниками для обеспечения своих войск. Выявлено, что на севере и северо-западе «белой» России наполнение бюджета осуществлялось в основном за счет неконтролируемой эмиссии денежных знаков, что раскручивало инфляцию и становилось одним из способов всеобщего принудительного налогообложения.

Ключевые слова: государственные образования, прямые налоги, косвенные налоги, контрибуции, реквизиции, налоговые органы, финансы, государственный бюджет.

\section{Abstract}

The article examines the problem of the activities of the anti-Soviet governments of the North and North-West of Russia in the tax sphere during the Civil War, which is poorly studied in the domestic historical and legal science. It is revealed that the tax legislation and administrative practice of state bodies were based on the laws of the former Russian Empire and the Provisional Government. It is established that taxation in the Northern region was carried out in line with the tax policy of the Russian government of Admiral A.V. However, the government set the structure of taxes and tax rates independently, based on regional conditions. It is determined that in an environment of galloping inflation and widespread legal nihilism, budget revenues from direct taxes amounted to negligible amounts. Indirect taxes were practically not collected due to the extremely weak development of industry and trade and the lack of necessary goods and services. It is established that due to the short duration of its existence and the insignificant territory under the jurisdiction of the white government, as well as the underdevelopment of entrepreneurship, taxes were replaced by requisitions conducted by military chiefs to provide for their troops. It was revealed that in the north and north-west of "white" Russia, the budget was filled mainly due to the uncontrolled issue of banknotes, which, in turn, spun inflation and thus emptied the treasury. Being the main source of filling the state budget, it has become one of the ways of universal compulsory taxation.

Keywords: state entities, direct taxes, indirect taxes, contributions, requisitions, tax authorities, finance, state budget. 
В Архангельской области и Мурманском крае в августе 1918 г. власть вместе с пустой казной перешла в руки антисоветского Временного управления Северной области (ВУСО), а с 9 октября 1918 по 18 февраля 1920 г. - Временного правительства этой области (ВПСО). В октябре 1919 г. по приказу адмирала А. В. Колчака верховным правителем этого региона «белой» России стал генерал Е. К. Миллер. Как и в других антисоветских государственных образованиях из-за хозяйственной разрухи налоговая система Северной области оказалась в глубоком кризисе (Об уплате налогов // Собрание узаконений и распоряжений Верховного Управления Северной области и Временного правительства Северной области ((СУР ВУСО и ВПСО)). 1918, ст. 411, 429). Не в лучшем положении оказались налоги на территории, находившейся под юрисдикцией Северо-Западного правительства генерала Н.Н. Юденича.

Перед этими правительствами стояла задача наполнить казну в условиях финансового хаоса, когда в стране в обращении находилось огромное количество различных денежных знаков и суррогатов. Так, к лету 1919 г. на территории Северной области имели хождение, помимо «керенок», «романовских», немецких и финских денег, еще и свои «моржовки» и «северные рубли» (Постановление правительства о предотвращении спекуляции денежными знаками // СУР ВУ и ВПСО. 1919, ст. 62); [1, 2008 , с. 34]. Аналогичное положение в финансовой сфере возникло и на Северо-Западе страны, где в обращении находились «петроградки», «крылатки», «шведские», «юденки» или «юденичи» и другие суррогаты [2, с. 112]. Кроме того, неконтролируемый выпуск советским правительством ничем не обеспеченных керенок на сумму примерно в 40 с лишним млрд. руб., которые к 1919 г. имели хождение по обе стороны фронта и, раскручивая инфляцию, привели к росту цен белее чем в 100 раз [3, c. 212].

Восстановление налоговой системы правительства Севера и Северо-Запада «белой» России осуществляли на основе дореволюционного законодательства и в соответствии с общим курсом правительства адмирала А.В. Колчака, что видно из доклада министра финансов омского правительства И.А. Михайлова Совету министров (Документы Совета министров // ГАРФ. Р-5863. Оп.1. Д. 3. Л. 352). Для координации действий управляющий Отделом финансов Северной области князь И. А. Куракин в конце апреля 1919 г. выезжал в Омск [4, с. 235].

По дореволюционному законодательству наполнение государственного бюджета осуществлялось в основном за счет прямых земельных налогов и налогов с недвижимого имущества, а также винной монополии (Циркуляр Главному управлению неокладных сборов и казенной продаже питей // Правительственный вестник, 1914, № 177, с. 3). С ухудшением собираемости земельных налогов в 1916 г. были приняты законы о прогрессивном подоходном налоге и налоге на прирост прибылей (Закон о государственном подоходном налоге // Собр. Узак. и Расп. Правит., 1916, № 106, ст. 838; Закон 13 мая 1916 г. о налоге на прирост прибылей // Практическое правоведение, 1916, с. 60), при этом Министерство финансов Временного правительства в связи с набиравшей обороты инфляцией 16 июня повысило налоговые ставки (О повышении налоговых ставок // Вестник Временного правительства, 1917, № 81) и 27 марта 1917 г. ввело запрет на продажу водки частными предпринимателями (О запрете продажи водки // Вестник Временного правительства, 1917, № 28/74). Также была введена монополия на продажу импортируемого из-за границы сахара (O сахарной монополии // Узаконения и распоряжения по продовольственному делу за 1914-1917 гг., Ч. 1, XCVI); [5, c. 142].

В Северной области структура прямых налогов (окладных сборов) не претерпела изменений. Она включала в себя подоходный, промысловый, поземельный налог и налог с недвижимости. Кроме того, правительством делались безуспешные попытки взимать установленные в царское время земские повинности на содержание полиции, судебных, административных и земских учреждений (Свод Устава о Земских 
Повинностях // ПСЗРИ (Полное собрание законов Российской империи). T. IV. Книга II, ст. 509, 510); [6, с. 168].

Планировалось также получать определённый доход от таможенных сборов. Однако таможенная служба на севере влачила жалкое существование. Пограничные таможни действовали только Архангельске и Мурманске. На остальной территории изза неопределенности границ и неупорядоченности процедур их пересечения в основном велась нелегальная мелкая торговля. В северо-западном государственном образовании таможни практически прекратили свое существование еще в ходе мировой войны.

В Северной области созданный державами Антанты Союзный комитет снабжения, осуществляя поставки грузов военного и гражданского назначения, при вывозе товаров не считался ни с какими таможенными правилами. Председатель комитета внешней торговли при правительстве Северной области П.Г. Калинин характеризовал действия союзников, как «вакханалию вывоза» (Материалы заседаний правительства // ГАРФ. Ф. 3694. Оп.1. Д. 13 Л. 17 об, 19, 20); [7, с. 105-108]. Экспорт и импорт товаров российских торгово-промышленников Северной области составлял всего лишь $16 \%$ от всех ввозимых и вывозимых грузов, что давало ничтожные поступления в казну [8, с. 96-99].

С началом гражданской войны в ожидании быстрой победы над большевиками все правительства «белой» России основные надежды в наполнении бюджета власти возлагали на добровольные пожертвования торгово-промышленных кругов, которые рассматривали эти взносы в качестве разовых прямых чрезвычайных налогов, вызванных условиями военного времени. Однако их патриотические настроения быстро угасли. В такой ситуации воинские начальники стали в принудительном порядке изымать у населения необходимые средства. [9, с. 113]. Кроме того, немногочисленные промышленники севера и северо-запада страны в ожидании лучших времен останавливали производство из-за опасения, что продажа произведенной продукции в условиях обесценивания денег не покроет издержек (Документы Отдела финансов ВПСО // ГАРФ. Ф. 16. Оп.1. Д. 20. ЛЛ. 120-122). В результате налоговые поступления в казну свелись к минимуму.

Население в условиях небывалой дороговизны продуктов и товаров жило одним днем без всякой надежды на будущее и, пользуясь слабостью власти, не собиралось платить никакие налоги. Кроме того, в Северной области после крестьянской реформы 1860-х гг. не было проведено даже предварительного межевания крестьянских и государственных земель. Едва начавшиеся в 1912 г. землемерные работы с началом войны были прерваны. В связи с этим в поземельном налогообложении царила неразбериха, несмотря на попытки правительства урегулировать вопросы аренды земли (вся земля считалась государственной) и размеров арендуемых участков (городских и сельских), как расчищенных от леса, так и подлежавших расчистке (О земельном налоге // СУР ВПСО. 1919. № 12, ст. 407). По словам Л.Г. Новиковой, между бывшими арендаторами церковных и казенных земель, и крестьянами, которые захватили их в ходе «черного передела» в 1917-1918 гг., между прежними и новыми владельцами лесных расчисток и даже между целыми волостями до конца существования этого государственного образования велись нескончаемые тяжбы [10, с. 171], что не могло не отражаться негативно на налоговых поступлениях.

На Северо-Западе России ситуация в налоговой сфере была еще хуже. Территория этого государственного образования к лету 1919 г. включала в себя незначительную часть Псковской и Петербургской губерний с тремя слабо развитыми в экономическом отношении и малонаселенными провинциальными городами Псковом, Ямбургом и Гдовом, но в августе Ямбург и Псков заняли войска Красной армии, и под юрисдикцией Северо-Западного правительства остался лишь Гдовский уезд [11, с. 325]. От проживающего здесь малочисленного населения, занимавшегося до войны в основном торговлей лесом, льном и пенькой ожидать каких-либо серьезных налоговых 
сборов не приходилось. Очевидно, поэтому в архивных источниках и мемуарах участников белого движения сведения о налоговых поступлениях в казну отсутствуют. Наполнение бюджета осуществлялось в основном за счет денежной эмиссии полевого казначейства (выпущено 1 млрд. 200 млн. руб. заказанных в Швеции так называемых «петроградок) [12, с. 131] и валютных переводов омского правительства, на общую сумму в 22,14 млн. франков [13, с. 101]. Но этих денег не хватало, в связи с чем СевероЗападное правительство оказалось в финансовом тупике, выход из которого виделся только в проведении реквизиций у населения.

Для создания видимости законности таких действий и предотвращения взрыва недовольства населения приказом генерала А.П. Родзянко по Военно-гражданскому управлению № 107 от 26 мая 1919 г. на территории этого государственного образования, которая, по-существу, представляла собой театр военных действий, было введено военное положение в соответствии Прил. 1, ст. 1, п. 2. «Положения о Полевом Управлении Войск» 1914 г. (ГАРФ. Ф. 6462. Оп.1. Д. 21. Л. 7.) Таким образом, реквизиции были узаконены, правда с некоторыми ограничениями. Их разрешалось проводить только на основании письменных предписаний с печатью полевого казначейства, за чем должны были следить уездные и волостные военные коменданты, олицетворявшие в соответствии с Положением «Об уездных и волостных комендантах» военную и гражданскую власть на местах [14, с. 178-179]. Однако работа их самих и подчинённых им канцелярий оставляла желать лучшего из-за отсутствия необходимых кадров. Они не в состоянии были контролировать действия воинских начальников, проводивших самовольные реквизиции скота и домашнего инвентаря у крестьян и заставлявших их выполнять бесконечные подводные повинности, зачастую в своих личных интересах [15, с. 134]. Это вызывало массовое недовольство населения, и многие крестьяне уходили в леса, пополняя ряды «зеленой» армии.

Помимо всего прочего, правительства генералов Миллера и Юденича оказались перед проблемой сбора подоходного налога, потому что более $90 \%$ населения территорий, находившихся под их юрисдикцией, составляли крестьяне. До революции этот налог с крестьян не взимался, а советское правительство перестало его собирать и с горожан. Немногочисленные городские жители всячески уклонялись от его уплаты, чему способствовала значительная миграция населения, в результате которой многие потенциальные налогоплательщики не улавливались налоговым аппаратом. К тому же, ввиду бедности основной массы населения налогоплательщики в лучшем случае могли вносить в казну, согласно закону, не более 2-3\% своих съедаемых инфляцией доходов, что никак не могло положительно сказываться на бюджетных поступлениях [16, с. 100].

Таким образом, налоги в государственных образованиях Севера и Северо-Запада страны не обеспечивали в условиях финансового хаоса и галопировавшей инфляции поступления в казну необходимых для снабжения армий и налаживания экономической и социальной жизни общества средств. Их собираемость была крайне низкой. В обстановке гражданского междоусобия и слабости власти население сопротивлялось налоговой деятельности белых правительств. Торговые и промышленные круги старались вывезти свои капиталы за границу и, пользуясь коррупционностью налогового аппарата, всячески уклонялись от уплаты налогов. В силу этого основным источником пополнения государственного бюджета стала безудержная эмиссия денежных знаков, которая разгоняла инфляцию и становилась, таким образом, одним из способов всеобщего принудительного налогообложения. Наряду с военными поражениями это явилось одной из важнейших причин краха антисоветских государственных образований в данных регионах «белой» России.

$$
* * *
$$

1. Овсянкин Е.И. Архангельские деньги. Архангельск: Правда Севера, 2008. 211 с.

2. Мерников Андрей. Деньги России. От монет Древней Руси до современных денежных знаков. М.: ACT, 2015. 240 c. 
3. Тимошина Т.М. Экономическая история России: Учебное пособие / Под ред. проф. М.Н. Чепурина. 15- е изд., перераб. и доп. М.: ЗАО Юстицинформ, 2009. 429 с.

4. Поморская энциклопедия: В 5 т. Т. 1. / Сост. А.А. Куратов. Архангельск: Поморский государственный университет, 2001. 483 с.

5. Сахневич И.В. Правовые основы продовольственной политики Временного правительства // Юридические записки. 2014. № 1. С. 138-143.

6. Ханафеев Ф. Ф. Исторические этапы становления и развития налогового администрирования в России // Инновационное развитие экономики. 2013. № 1(13). С. 165-173.

7. Голдин В.И. Интервенция и антибольшевистское движение на Русском Севере. 1918-1920. М.: Изд-во МГУ,1993. 200 с.

8. Добровольский С.Ц. Борьба за возрождение России в Северной Области // Архив русской революции. Т. 3. Берлин, 1921. С. 5-147.

9. Карпенко С.В. Налоговая политика белых правительств на юге России в 1919-1920 гг. // Экономический журнал. 2011. №4 (24). С. 111-121.

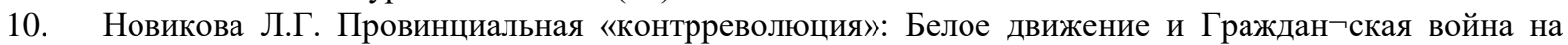

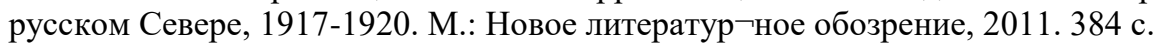

11. Цветков В. Ж. Белое дело в России. 1919 г. (формирование и эволюция политических структур Белого движения в России). М.: Посев, 2009. 636 с.

12. Ходяков М.В. Деньги гражданской войны и их роль в обеспечении легитимности белогвардейских правительств // Вестник СПбГУ. 2007. № 2. С. 125-133.

13. Владимирский М.В. Финансовая деятельность Северо-Западного правительства. 1919-1921 гг. // Вопросы истории. 2011. № 4. С. 94-110.

14. Смолин А. В. Белое движение на Северо-Западе России. 1918-1920. Санкт-Петербург: Дмитрий Буланин (ДБ), 1999. 439 с.

15. Васильев М. В. Административно-хозяйственная политика Белого Северо-Западного правительства в Псковской губернии (1919 г.) // Псков. 2015. № 42. С. 131-138.

16. Рынков В.М. Экономическая политика контрреволюционных правительств в Сибири. 1918-1919. Дисс. ... канд. ист. наук. Новосибирск, 1998. 308 с. 


\section{For notes}




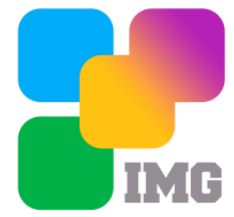

Scientific publication

\section{General question of world science}

The collection of scientific papers of the materials International scientific conference «General question of world science»

15 October 2021 